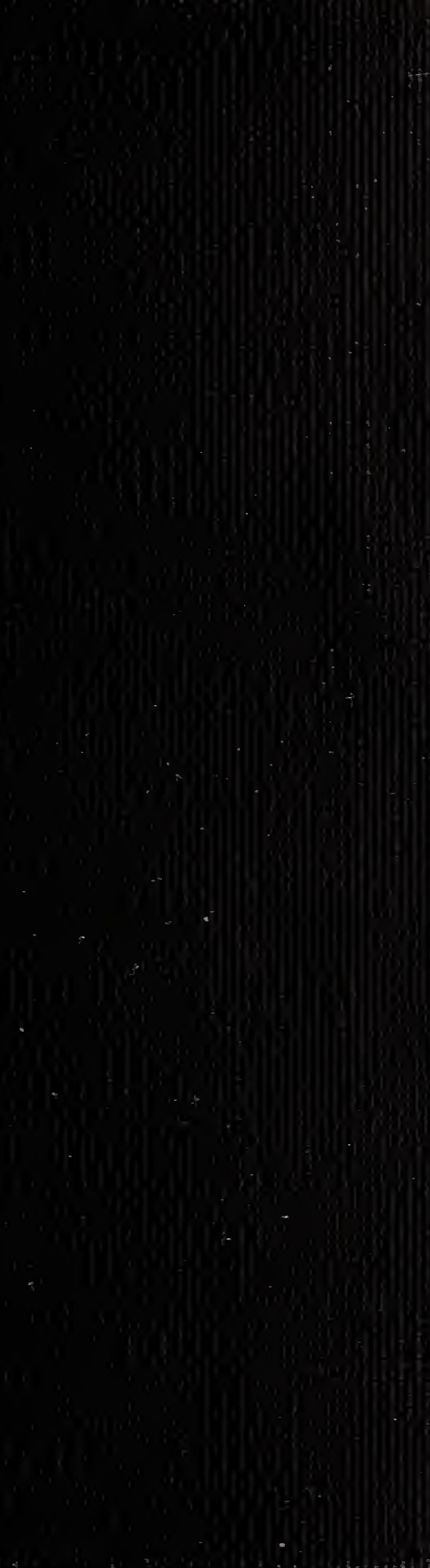








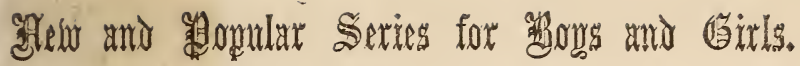

\section{THE AIMWELL STORIES;}

A SERIES OF VOLUMES ILLUSTRATIVE OF YOUTHFUL CHARACTER, AND COMBINING INSTRUCTION WITH AMISEMENT

\section{BY WALTER AIMWELL,}

Author of "The Boy's Own Guide," "Boy's Book of Morals and Manners," \&c, WITH NUMEROUS ILLUSTRATIONS.

Price

The rolume eratzin about 300 pages, $16 \mathrm{mo}$, each, bound in cloth, with gilt backs IET Each roiume is complete and independent of itself, but the series will be cor nected together by a nartial identity of characters, localities, \&c.

The first six volumes of this series are now ready. They are entitled:

OSCAR; 0i, the Boy who had his orrn Way.

CLIITOS; or, Boy-Life in the Country.

RLLA; or, Turning Over a New Leaf.
HHISiLER; or, the Manly Boy.

MARCTS ; or, the Boy-Tamer.

JESSIE; or, Trying to bo Somebody.

\section{NOTICES OF TEE PRESS.}

There is a fresh, breezy tone about his boys' stories, and a thoroughly domestio air in the girls', that give them vraisemblance and attractiveness. The little trials of temper, and effects of seemingly trifling habits, are well and accurately related, and with a skill scarcely inferior to Miss Edgeworth's. - Huntington's Monthly Religious Magazine.

We hardly think a better series of books for children were ever written.-Youth's Companion.

Having examined them more carefully, we would still more strongly commend them as among the very best and most interesting volumes prepared for the young. - Conn. Common School Journal.

In the department of juvenile literature, the "Aimwell Stories' have fairly come to rival the 'Rollo Books' in the affections of the young people. The author when he conceived the plan of the series, struck a vein which he has since been working with rich and constantly increasing success.-Boston Transcript.

Ine of the best series for the young ever written. Every family of children

it to have them.-Chicago Congregational Herald.

1.ey are written with great skill for the tastes and necessities of children and wisy written conscientiously, with a moral and Christian effort unobtrusively operative upon every page.-Congregationalist.

A better series of books for children was never written. The author has studied deeply and accurately the feelings, hopes, and thoughts of youth.-Boston Mail.

The author of the 'Aimwell Stories' has a happy knack at combining amusement and instruction. Under the guise of a story, he not only teaches a moral lesson, which is or ought to be a leading object of every tale for children, but he gives his readers instruction in philosophy, geography, and various other sciences. So happily are these introduced, however, that the youthful reader must learn in spite of himself.-Boston Journal.

It is the best series of juvenile books with which we are acquainted.-Northampton Gazette.

We have spoken repeatedly, and with unqualified commendation, of this series of juvenile volumes. It would be difficult th exaggerate their merits as a sousice of nmuvement and instruction to clildren.-American Patriot. 


\section{YALUABLE WORKS FOR THE YOUNG.}

YOUNG AMERICANS ABROAD; or, Vacation in Europe : the Results of a Tour through Great Britain, France, Holland, Belgium, Germany, and Switzerland. Ly John Overton Choules, D. D., and his PUPILs. With Elegant Illustrations. 16mo, cloth,

A highly entertaining work, embracing more real information, such as every one wishes to know about Europe, than any other book of travels ever published.

Three intelligent lads, who knew how to use their eyes, accompanied their tut s ol. a European tour; and, from a carefully-kept journal, they wrote out, in a series ? letters to a favorite companion in study, at home, their impressions of the most ta markable places en route. The pencillinss are genuine and unaffected, and in ald respects form an interesting aid instructive record of trevel. - Sartain's Magazine.

One of the most instructive and delightful books of the age. - Southerm Lit. Gaz.

Boys, here is a book that will suit you exactly. It is a series of letters from ceriain boys travelling in Europe to their classmates in this country. It will improve your knowledge and amuse you during long winter nichts. - Methodist Prot.

It is worth much more than many a larger and more pretenticuv volume, for giving a daguerreotype of things abroad. - Cong" yationalist.

$A$ beautiful book for young people, unlike any thin $n_{b}$ we have erer seen. $-C h$. Ob. Most interesting book that can be put irto the hancisnf tre young, - Olive Braneh

The best book of foreign travel for youth to be found in tie whole rage of Amercan literature. - Buffalo Morning Express.

\section{THE ISLAND HOME; or, the Young Castaways. By}

Christopher Romaunt, Esq. With Elegant I'lus.rations.

The best and prettiest book for boys that we have lately secn - Boston Posk

A stirring and unique work. It will interest the juvenile men vasi'y. - Oive Br.

Delightful narrative of the adventures of six boys wh ' put to sea $i$ an open boat. and were drifted to a desert island, where they lived in the manner of Robinson Crus soe, - N. Y. Com.

A book of great interest, and one which will be a treat to any boy. - Havia Circle.

The young will pore over its pages with almost enchanted interest. - Trmicript.

A modern Robinson Crusoe story, without the dreary solitude of that iamers hero It will amuse and instruct the young in no ordinary degree. - Southern Lit. Gizette

A story that bids fair to rival the far-famed Robinson Crusoe. We becom? as thuch interested in the Max, Johnny, Arthur, and the rest of the goodly company, as ir tho 6wiss Family Robinson. - Sartain's Magazine.

\section{IHE AMERICAN STATESMAN; or, Illustrations of th}

Life and Character of DANIEL WEBSTER, for the Entertainment an

Instruction of American Youth. By the REv. JOSEPII BAN ${ }_{\text {SRD, al }}$ thor of "Plymnuth and the Pilgrims," "Novelties of the New Worla,",

"Romance of American History," etc. With elegant Illustrations.

or A work of great interest, presenting a sketch of the most striking and impur. tant events which occurred in the history of the distinguished statesman, Daniel Webster, avoiding entirely all points of a political character; holding up to view. fot the admiration and emulation of American youth, only his commendable traits of character. It is just such a work as every American patriot would wish his childrev, en rearl and refiret upon. 
HOF, 20 BE A MAN; a Book for Boys, containing Useful Hints on the Formation of Character. Cloth, gilt.

"My design in writing has been to contribute something towards forming the character of those who are to be our future electors, legislators, governors, judges, ministers, lawyers, and physicians, - after the best model. It is intended for boys - or, if you please, for young gentlemen, in early youth." - Preface.

I "How to be a Man " is an inimitable little volume. We desire that it be widely eis calated. It should be put into the hands of every youth in the land. - Tenn. Bap.

\section{HOW TO BE A LADY; a Book for Girls, containing Useful}

\section{Hints on the Formation of Character. Cloth, gilt.}

"Having daughters of his own, and having been many years employed in writing for the young, he hopes to offer some good advice, in an entertaining way, for girls or misses, between the ages of eight and fifteen. His object is, to assist them in forming their characters upon the best model; that they may become well-bred, intelligent, refined, and good; and then they will be real ladies, in the highest sense." - Preface.

Parents will consult the interests of their daughters, for time and eternity, in making them acquainted with this attractive and most useful volume. - N. Y. Evangelist.

\section{The following Notices apply to both the above Volumes.}

It would be better for the next generation if every youth would "read, learn, and in wardly digest" the contents of these volumes. $-N$. $Y$. Commercial.

These volumes contain much matter which is truly valuable. - Mfer. Journal.

They contain wise and important counsels and cautions, adapted to the young, and made entertaining by the interesting style and illustrations of the author. They are fine mirrors, in which are reflected the prominent lineaments of the Christian young gentleman and young lady. Elegant presents for the young. - Anerican Pulpit.

Newcomb's books are excellent. We are pleased to commend them. $-N$. Y. Obs.

They are books well calculated to do good. - Phil. Ch. Chronicle.

Common-sense, practical hints on the formation of character and habits, and are adapted to the improve ment of youth. - Mothers' Journal.

\section{ANECDOTES FOR BOYS; Entertaining Anecdotes and} Narratives, illustrative of Principles and Character. $18 \mathrm{mo}$, gilt.

\section{ANECDOTES FOR GIRLS; Entertaining Anecdotes and}

Narratives, illustrative of Principles and Character. 18mo, gilt,

Interesting and instructive, without being fictitious. The anecdotes are many. short, and spirited, with a moral drawn from each, adapted to every age, condition, and duty of life. We commend them to families and schools. -- Albany Spectator.

Works of great value, for a truth or principle is sooner instilled into the youthful heart by an anecdote, than in any other way. They are well selected. - Ev'g Gaz.

Nothing has a greater interest for a youthful mind than a well-told story, and no medium of conveying moral instructions so attractive or so successful. The influence is far more powerful when the child is assured that they are trice. We cannot wo strongiy recommend them to parents. - Western Continent, Baltimore. 




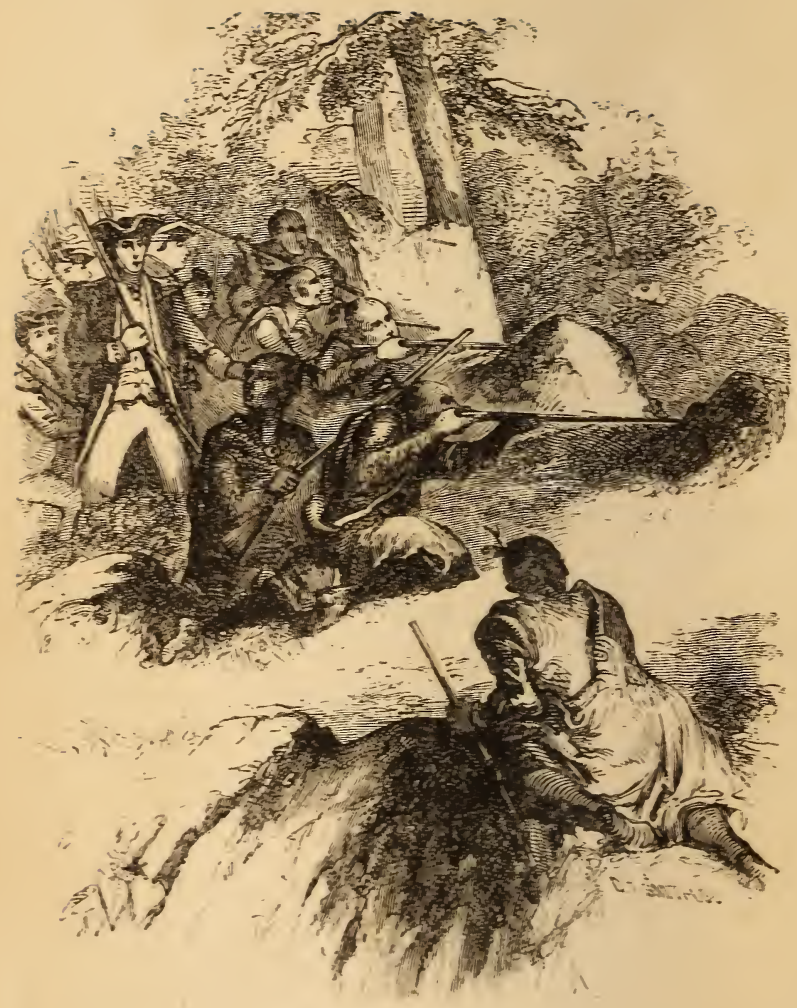

IXDLAN IN AMBLSH. 


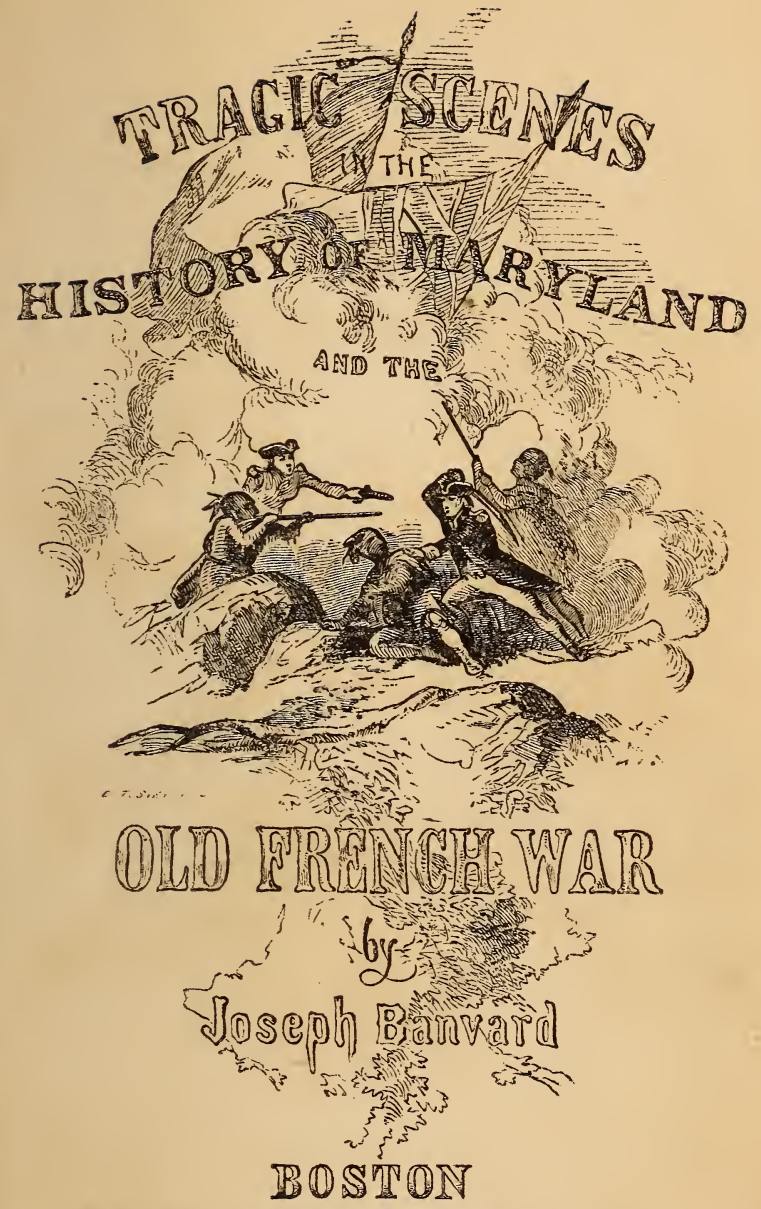

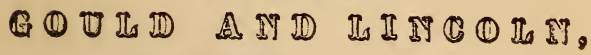

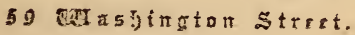





\section{TRAGIC SCENES 1866 NMAH \\ IN THE}

\section{HISTORY OF IIARYLAND}

$\triangle \mathrm{ADD} T \mathrm{HE}$

\section{OLD FRENCH WAR.}

WITH AN ACCOUNT OF

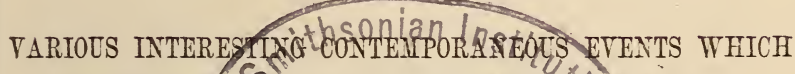
OCCURRED IN THE EARLY SETTLEMEIT OF AMERICA.

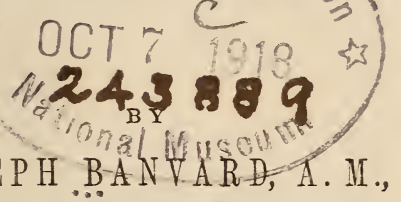

JOSEPH BAN VARD, A. II.,

AUTHOR OF "PLYMOUTH AND THE PILGRIMS," "NOVELTIES OF THE NEW WORLD," "BOMANCE OF AMERICAN HISTORY," ETC. ETC.

\section{BOSTON:}

\section{GOULD A N D L I N C O L N,}

59 W A S H INGTON STREET.

NEW YORK: SHELDON, LAMPORT \& BLAKEMAN,

115 NASSAC STREET.

1866 . 
Entered according to Act of Congress, in the year 1856, by GO LLD A N D L N O L N,

In the Clerk's Off.ce of the District Court, of the District of Massachusetts.

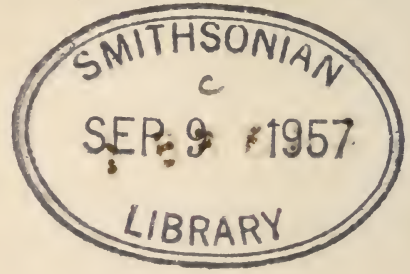

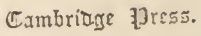

DAKIN A N D METCALF. 


\section{P R E F A C E.}

The discovery of the New World by Christopher Columbus, and the glowing description which was given of it by Americus Vespucius, aroused the governments of Europe to a perception of the importance of forming settlements in these new domains, and thus, by virtue of the right of discovery, or when this could not be urged, then by priority of possession, obtaining a title to some portions of its vast territory, which they might ever after hold as colonial dependencies. Accordingly, towns were built along its coast, and forts erected in the interior by subjects of different nations. As time rolled on, and enterprising pioneers pushed their explorations further from the original settle- 
ments, they came in contact with each other. Then arose mutual accusations of trespassing beyond authorized limits. Collisions and wars were the consequence, until, after the expenditure of much treasure and blood, the Dutch and the French were subdued, and nearly the whole of North America came into the possession of the English.

After this, the British Parliament, by a series of indiscreet and oppressive acts, greatly irritated the colonies, and effectually alienated them from the mother country. The development of these facts, with an account of other cotemporaneous events of an interesting character in the history of our country, and especially in connection with Maryland, is the object of the present volume. 


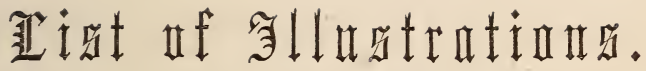

I. FRONTISPIECE

II. ILLUSTRATED TITLE PAGE

III. DOG HUNTING A STAG, $\ldots \ldots \ldots \ldots \ldots \ldots \ldots \ldots \ldots \ldots . .86$

IV. ENCAMPING FOR THE WINTER .............. 95

V. INDIAN AMBUSH......................... 150

VI. HENDRICK AND THE STICKS................ 166

VII. LANDING AT LOUTSBURG.................... 182

VIII. SEARCHING FOR THE DEAD $\ldots \ldots \ldots \ldots \ldots \ldots \ldots \ldots . .212$

IX. THE INDIAN WARRIOR $\ldots \ldots \ldots \ldots \ldots \ldots \ldots \ldots \ldots \ldots . .217$

X. ASCENDING THE HEIGHTS OF ABRAHAM......... 226

XI. HOOD RIDING IN EYFIGY .................... 235 



\section{O N T E N T S.}

\section{H A P T E R I.}

Painful Discovery-Religious Dissensions-Persecutions overruledThe Baron of Baltimore-An impracticable Measure-The Three Calverts-An Error-The "Ark" and "The Dove"-The Arrival at the New World-The Jesuit's Narrative-Pirates and Perils-Intrepid Captain-Violen $\hat{\imath}$ Storm-Lights at Masthead-"The Dove" disappears-Perils and Prayers-Insurrection-Fears allayed-Boat Upset-Interview with the Natives-Their singular Opinions-An adopted Indian-A discreet Answer-English Policy-A Treaty....

\section{H A P T E R II。}

A favorable Circumstance-First Buildings erected-An Indian honored-Honor Misunderstood-A Gala-day-Imposing CeremoniesWhites and Indians living together-Nature of the Soil-Prepared for Planting-Clayborne's Conduct-He is frustrated-He is conquered and sent to England-His Deception there-His Trial and its Results-Clayborne and Ingle-Governor Calvert flees-Disorder prevails-Records lost-Session of the Assembly-Governor FillPeculiarities........................................ 


\section{HAPTER III.}

Colonists to scatter-Foresight of Lord Baltimore-Conditions of Landgrants-Special Instructions-Courts Baron and Courts Leet-Their Uses-Remnant of the Feudal Ages-Manors of Lands-Important Feature-Failure of the Aristocratic Element a Cause of Thanksgiving..................................................

\section{H A P T E I V.}

Erroneous Inferences-Religious Liberty-When it is Defective-Charter and Laws of Maryland-Conformity to the Ecclesiastical Laws of England-Union of Religion and civil Government-Religious Toleration-Reproachful Terms forbidden-Penalty for using themLiberty limited-Oppressive Laws-The Difference in Rhode Island -Influence of Protestantism-Liberal Prtnciples.

\section{H A P T E R}

Law against Stealing One's self-Arbitrary Distinction-Influence of the Roman Catholic Priests-Importance of little Knowledge-Peculiar Law-Curious Definition of Drunkenness-Its Penalty-Law enjoining Fasting-Laws respecting Tobacco and Corn-Corn to bo twice shaken-Corn Hand-mills-Water-mill Tax-Saw-mill destroyed in London-Reasons for Indian Fears-Ancient Feuds among the Indians-Indian Opinions-Collision with the Indians-Warlike I'reparations-The Maquantequats-The Patnxent Indians-They

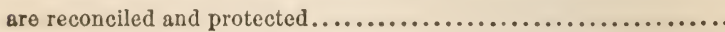




\section{H A P T E R V I.}

Colonies multiplied-Captain Lucas Fox-His Voyage to the Northern Regions-Dangers from the Ice-How Ice bergs are formedDescription of a Sea Unicorn-Variation of the Needle-Reasons for it-Geological Discovery-A White Bear floating upon Ice-Its Pur. suit and Capture-Petty Dancers-Hunting Swans and SealsGraves Discovered-Dog hunting a Stag-School of Whales-A Dun Fox-Remains of Captain Button's dwellings-Going a BerryingA Cross found-Seeking a Main yard-The Maria met with-Captain Fox names various Places-Fox's Return.................

\section{H A P T E R VII.}

Captain James sails for the North-His trying Position-He is Frozen in-James's Ignorance-Dangers to which it leads-Encamping for the Winter-Peculiar Features of a northern Winter-The Scurvy -Its Symptoms-Effects of Extreme Cold-Difficulty of Working - Thawing Trees-Medical Treatment-A singular PhenomenonFinding the Rudder-Disappointment-Difficulties multiplied-Sick recovering-Homeward Departure-False Facts................

\section{CHA P T E R V III.}

De Groslie-Information from the Ottowas-Hunters and TrappersDe Vries's Voyage-Smelling the Land-A Dreadful Scene-Its Perpetrators unknown-The Particulars-Effects of Confidence-Indian 
Treachery and Revenge-Peace concluded-Beans wanted-Startling Intelligence-Boat's Crew murdered-A suspicious CircumstanceChief's Visit-Gifts given and refused-A Peach-tree found-Interriew with the English-Seven Whales taken-Whaling unprofitable.

\section{H A P T E R IX.}

Gustarus Adolphus-His Plans of Emigration-A War defeats themDeception of the Swedish Governor-Fort Casimer taken by Treachery-Governor Stuyvesant attacks Delaware-Army of Seven Hundred-Stuyvesant's triumphant Advance-He conquers DelawareRumors of a silver Mountain-An Indian brings Ore-He is assassinated-The English conquer the Dutch-Children stolen by the Savages-Their Redemption-price in Tobacco-Commercial Regulations-The Famous Navigation Act..........................

\section{CHA P TER X.}

A remarkable Fact-Political Troubles-Seizure of $\Lambda$ rms and Ammunition-Resisting Authority-Tho Governor's Protest-A noble I.esolution- $\boldsymbol{\Lambda}$ Boat seized-Terrific Threatenings- $\boldsymbol{\Lambda}$ Council of War-The "Golden Lyon" $-\Lambda$ deceptive Trick-Stone flred uponA Battle-The Victory-The Prisoners-The first Account sent bome-Reconciliation between Prrotestants and Catholics. 


\section{H A P TER XI.}

Peace and Prosperity-A great Country-Its Possession desirableOrigin of the French War-Chain of Forts-Preparation for a Campaign-Franklin's Patriotism-Braddock's Arrival-George Washington becomes Braddock's Aid-de-Camp-Washington sick-A Wagon his Hospital-March of the Army-A beautiful Sight-An invisible, terrible Foe-Indian Ambush surprises the Army-Washington's Perils and Escapes-The Killed and Wounded-Singular Interview between Washington and an Indian-The Indian's Story His Reverence for Washington..........................

\section{CHA P T R XII.}

Savages offer their Services-The Offer unwisely rejected-Washington's Fame-Davies's Allusion to him Prophetic-Thirst for BloodThe Moravians attacked-Dreadful State of Things-A marvelous Escape-Scalp lost-Great Panic-Reward of ten Pounds for an Indian's Scalp....................................... 155

\section{H A P E R XII.}

Design of the French-Crown Point-Johnson and the Indian Chief Hendrick-Baron Dieskau-Indian Mode of numbering-Indian Battle-An eloquent Indian Chief-Important military PrincipleEffects of Delay-Battle of Lake George-Death of Baron DieskauRetreat of the French-Effect of the Victory-Johnson highly honored-His selfish Meanness..-A new Principle............. 164 


\section{H A P T E X X V.}

Marquis de Montcalm-Forts at Oswego-Violent Midnight AttackFort Ontario taken-Colonel Mercer killed-No aid to be obtained -The English capitulate to the French-Terms of Capitulation shamefully violated-Montcalm destroys the Forts-Lord Loudon's Expedition-Montcalm's Barbarity-Munro's sad Discovery-Tho English yield to Montcalm-Terms of Capitulation-Wilfull Deception-Indignation of the Savages-Their horrid Cruelties-Effects of the Fall of Fort William Henry-The Massacre attributed to Liquor.

\section{CHA P T R X V .}

Pitt farors Liberty-Three important Expeditions-Attack upon Louisburg-Landing in a Storm-Brave Attack and Defense-American Gibraltar-Bombardment-The City taken-Great Joy in England-Soldier's Wit-Disappointment in France-French commander degraded-Montcalm at Ticonderoga-His Intrenchments - Abercrombie on Lake George-A Battle in the Woods-Lord Howe slain-Assault of Ticonderoga-The Repulse-English want Cannon-Disheartening Effects.......................... 180

\section{H A P T E X VI。}

Activity of the French-Attempt to Intercept them-Injudicious Sport-A Skirmlsh tho Consuquence-Putnam a Prisoner to tho 
Indians-Is tied to a Tree to be burned-His Thoughts-His Deliverance-Colonel Bradstreet's Proposition-The Expecition agailust Fort Frontinac-State of Things at Oswego-Attack upon Frontinac -Indian Deserters-Frontinac taken-Munitions of War obtainedArmed Vessels seized-The Fort leveled-English encouraged.... 193

\section{H A P T E R X VII.}

A new Expedition against Duquesne-A new Road proposed-Washington opposes it-The Decision - Washington requests to be in the Front of the Army-Grant's Folly-Unexpected Attack-Injudicious Conduct of the Highlanders-Panic of the Pennsylvanians-Method of the Marylanders-Conduct of Washington-Grant, a PrisonerCouncil of War-Going into Winter Quarters-Loyal HanningAnother Fight-Sad Mistake-Indian Policy-Indian DesertersProvincials the best Soldiers-Fort Duquesne taken-Name altered to Fort Pitt-Pay of the Soldiers........................ 19

\section{CHA P T E R VIII.}

Indian Deputations-An affecting Duty-Searching for the DeadA singular Incident-Dreadful Mrementoes-Tragic Scenes-Battle of Niagara-French Defeated-Surrender of the Garrison-No Retaliation-Captive Soldiers sent to Albany-Women and Children sent to Quebec-French Communication between Canada and Louisiana destroyed................................... 20 


\section{CHA P T R XIX.}

Situation of Quebec-Its strong Defenses-Montcalm's Army-His Military arrangements-A Fleet of Fire-ships-How they are disposed of-Datteries erected-Terrific Fire-stages-Battle of Montmorency-il.-judged Assault-The English repulsed-The French fire upon the Wounded and the Dead-Their Apology for this CrueltyGeneral Wolfe sick-A perilous Project-Wolfe approves it-Its great Difficulties-Courageous Midnight Adventure-Heights of Abraham gained-Preparations for Battle-Position of the two Armies-Battle on the Heights-Wolfe's Death in Victory-The French Defeated-Death of Montcalm-Quebec taken by the En-

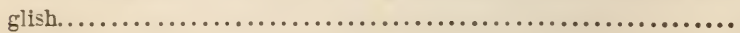

\section{H A P T R X X.}

Oppressive Acts of the British Parliament-American Opposition to them-Famous Stamp Act-Its Design-Its Effect in Maryland-The Maryland Gazette-Treatment of Zechariah Hood-Stamped Paper not allowed to be landed-A ridiculous Ceremony-Hood whipped and burned in Effigy-Popular Feeling more powerful than Government-The Times doleful and dollarless-Stamp Act repealed....... 


\section{T R A G I C S C E N E S.}

\section{CHAPTER I.}

Painful Discovery-Religious Dissensions-Persecutions Over-ruled-The Baron of Baltimore-An Impracticable Measure-The Three CalvertsAn Error-" "The Ark" and "The Dove"-Arrival at the New WorldJesuit's Narrative-Pirates and Perils-Intrepid Captain-Violent Storm -Lights at Mast-head-_"The Dove" disappears-Perils and PrayersInsurrection-Fears allayed-Boat Upset-Interview with NativesTheir singular Opinions--An adopted Indian-A discreet AnswerEnglish Policy-A Treaty.

The first explorers and settlers of this country experienced difficulties, and passed through perils, which are not easy for us, in our circumstances of safety, fully to appreciate. In a new world; with a climate to which they were unaccustomed; surrounded by barbarous tribes; withont dwellings, and with no lands prepared for cultivation, they were, at times, placed in circumstances of extreme perplexity. The deceitful and jealous savages were to be closely watched; the severities of winter were to be guarded against; forests to be felled. 
and converted into timber; suitable houses to be reared, and lands cleared and prepared for the plow.

Then, at a later period, after the colonies were permanently established, misunderstandings ensued between them, which resulted in war. The mother countries, to which these colonies belonged, sympathized with them, and took part in a contest that furnished many tragic scenes. Some of the more important of these scenes, together with interesting incidents which occurred about the same time, in the explorations made by adventurous navigators along the coast and rivers, will be described in the following pagres.

In the contemplation of the history of the past, there are few things that awaken more painful emotions than the discovery of the bitter hostility which existed between different denominations of professed Christians, and the cruel methods by which that hostility was developed.

After the discovery of North America by the Cabots, when its fertile valleys and boundless prairies were under the dominion of barbarous tribes of Indians, the civilized nations of Europe were convulsed with internal dissensions. Different classes of religionists were arrayed in bitter animosity against each other. They were not satisfied with the privilege of receiving and practicing whatever 
they believed to be in accordance with the will of God. Each was anxious that all others should receive his creed, and conform to his ritual; and as, in accordance with the vicissitudes of the times, one party or the other obtained the reins of government, did they use their power to coerce others to the adoption of their views. If this was not effected by mild discipline, more stringent measures were used. Hence the severe enactments which were passed by different administrations against opposite sections of the Christian Church. At one time, puritanism, at another time, episcopacy and catholicism were made to suffer.

It is interesting to observe how the exhibition of the unlovely elements of human nature in this exercise of spiritual despotism, was orer ruled, so as to promote civil and religious freedom. The cruelties to which different classes of Christians were subjected in the Old World, on account of their religious opinions, were the reasons of their flight to the New. As they desired to go where they would not be molested for their opinions; where fines and confiscations, prisons and tortures, would not be the reward of their adherence to what they conscientiously believed to be truth; and as the newly-discovered continent, situated three thousand miles from their own land, seemed to offer them the safest asylum, they naturally looked to that as the place 
of their retreat. It was in this manner that the iron hand of despotism scattered the seed of which our free institutions are the fruit.

Religious persecution was the immediate cause of the flight of the Puritans to New England, and of the Roman Catholics to Maryland.

George Calvert, a distinguished Papist, who was highly esteemed by King James-from whom he received the title of Lord Baron of Baltimore in the kingdom of Ireland-attempted to establish a colony of Roman Catholics in Newfoundland. When experience convinced him of its impracticability, he turned his attention to the more favorable climate of Virginia, of which he had heard the most glowing accounts. Being very coolly received by the colony already established there, he conceived the idea of forming a settlement on Chesapeake Bay, somewhere above the river Potomac.

As the charter of the London Company, under which the colonies in Virginia had been established, was dissolved, the king assumed the right of regranting such parts of the territories of Virginia as had not been parceled out into small portions to particular individuals. It was not difficult, therefore, for Lord Baltimore, who stood high in royal estimation, to obtain the promise of such a portion as he described to his majesty. But before the patent could be drawn up and receive the seals of 
office, Lord Baltimore died. His eldest son, Cecilius, was, by the laws of England, heir to the title and the estate of his father. To him the patent of lands in America, designed for his father, was executed. The portion of country which was embraced in this patent, or charter, was intended to hare been called Crescentia, but, at the suggestion of the king, it was changed to Maryland, in honor of his queen, Henrietta Maria.

Cecilius Calvert, who was now called Lord Baltimore, went zealously to work to hunt up colonistes, and prepare conveniences for them to remore to the New World. Impediments were thrown in his way by the Virginia Company, who seem to have supposed that the lands which they had obtained and cultivated, were about to be taken from them, and assigned to this new company. But this error being corrected, and certain orders in council being passed, which were binding upon both of the colonies, and designed for their equal benefit, Lord Baltimore was enabled to proceed in making the necessary arrangements for the new settlement.

It was the original intention of Baltimore to have come to Maryland with his colony, but this he subsequently abandoned, and appointed his brother, Leonard Calrert, Esq., to go in his place; whom he also made Governor for the administration of the affairs. With him were associated Jeremy Hawley 
and Thomas Cornwallis, Esqs., as assistants, or counsellors.

Calvert succeeded in awakening sufficient interest to induce about two hundred, among whom were persons of fortune and rank, to unite with him in the enterprise, the most of whom were Roman Catholics. All things being ready, the emigrants set sail from Cowes, in the Isle of Wight, on Friday the 22d day of November, in the year of our Lord 1633. They embarked in two ressels, one a ship called "The Ark," and the other a small pimace called "The Dore." Taking the course to America which, in those early times, was usually pursued, by the Azores and the West Indies, they stopped at the islands of St. Christopher's, and Barbadoes, where they lingered some time, probably, because they did not want to come upon the coast of North America in an umpropitióus season of the year, when the attempt to establish a settlement and build a town would be attended with great inconreniences, and perhaps painful privations. In consequence of these delays, they did not reach Virginia until the 24th of February, at which time they arrived at Point Comfort.

As a narrative of that voyage, written by one of the company, has come down to us, we cannot do better than to give a considerable portion of it in the language of the writer himself. The author is 
Father Audrew White, a Jesuit Missionary, who accompanied these first settlers to Maryland, and who wrote an account of the voyage in Latin, which account is among the archives of the Jesuits at Rome, from which the following extracts were translated,*

"On the 22d of November, being St. Cecilia's day, under the gentle influence of an eastern wind, we dropped down from the Isle of Wight. Haring placed our ship under the protection of God, the Blessed Virgin Mother, St. Ignatius, and all the guardian angels of Maryland, we had progressed but a short distance, when we were obliged, for the want of wind, to cast anchor off the fortress of Yarmouth, where we were welcomed by a salute. While here, we were not without some apprehensions from our sailors, who began to murmur among themselves, alleging that they expected a messenger from land with letters; and because none arrived, they seemed disposed to create delays. A kind Providence put an end to our fears; for during the night a strong, but favorable, wind sprang up, and our pinnace, $f$ which apprehended an attack from a French brig that kept within a short distance of her, took advantage of the wind and put to sea.

- Annals of Annapolis.

+ The pinnace appears to have been a sloop of about forty tous, called "The Dore." 
We, not willing to lose sight of her, followed her with all speed, and thus frustrated the evil designs of our sailors. This was on the night of St. Clement's day, the $23 \mathrm{~d}$ of November. On the next morning, about ten o'clock, after recerving a second salute from the fort at Hurst, we were carried beyond the breakers at the extremity of the Isle of Wight; and narrowly escaped being driven on shore. Taking advantage of a strong fair wind on that day and the next night, we left the western point of England, slacking sail, lest, running ahead of the pinnace, she might fall into the hands of the pirates and Turks, who then infested these seas. On the 24th of November, we made great headway until evening, when a violent storm arose, and our sloop, being diffident of its strength, being only of forty tons burden, hove to, and informed us that, in case of danger, she would carry lights at her mast-head. We were in a well-built ship* of four hundred tons, as strong as iron and wood could make her, and our captain was one of great expericnce. The storm was so riolent that we gave him the choice of returning to England, or pursuing the voyage. His intrepidity and confidence in the untried powers of his ship, induced him to choose the latter. But in the middle of the night, in a boiling 
sea, we saw our sloop at a short distance from us, showing two lights at her mast-head. Then, indeed, did we fear for her, and in losing sight of her we all supposed she had been swallowed up in the stormy sea. Six weeks elapsed before we again heard from her. But God had preserved her. Fearing that she could not survive the storm, she changed her course, and took refuge in the Scilly Isles. She afterwards sailed in pursuit of us, and we met at the Antilles. On the 27 th and the 28 th we made but little progress. On Friday, 29th, a most dreadful storm arose, that made the most fearless men tremble for the result. Among the Catholics, however, it made prayer more frequent; vows were offered in honor of the Blessed Virgin Mother, and her immaculate conception, of St. Ignatius, the patron saint of Maryland, St. Michael and all the guardian angels. Each one prayed earnestly to expiate his sins through the sacrifice of penance. For, having unshipped her rudder, our vessel was tossed about at the mercy of the winds and waves. At first I feared that the loss of our ship and death awaited me. But after spending some time in prayer, and having declared to the Lord Jesus, and to his Holy Mother, St. Ignatius, and the protecting angels of Maryland, that the purpose of this voyage was to pay honor to the blood of our Redeemer, by the conversion 
of barbarians, I arose with a firm confidence that through the mercy and goodness of God, we should escape the dangers that seemed to threaten our destruction. I had bowed myself down in prayer during the greatest rage of the tempest, and, let the true God be glorified! scarcely had I finished, before the storm was ceasing.

"I felt myself imbued with a new spirit, and overspread with a flood of joy and admiration at the benevolence of God to the people of Maryland, to whom we were sent. Blessed forever be the merciful charities of our dear Redeemer. The remainder of the voyage, which lasted three months, was prosperous. Our captain affirmed that he never witnessed a more pleasant and happy one. The period of three months included the time we spent at the island of the Antilles, but we were, in fact, only seren weeks and two days at sea. In sailing along the Spanish coasts we were* apprehensive of falling into the hands of the Turks, but we never met them. Having passed the Pillars of Hercules and the Madeira Islands, we were able to scud before the wind with full sail. The winds are not variable in those regions, but always blow in a south-west direction, which was our exact course. At the distance of about three leagues from us, we descried three sail of vessels, the smallest of which enpeared to be larger than ours. Fearing they 
were Turkish pirates, we were careful to aroid them, though we prepared our vessel for action. But as they showed no disposition to engage us, we concluded they were merchantmen, bound for the Fortunate Islands, and as much afraid of us as we were of them. * * * During the entire royage no person was attacked with any disease-except that at Christmas, wine having been freely distributed in honor of that festival, several drank of it immoderately; thirty persons were seized with a ferer the next morning, of whom twelve died shortly after; of these, two were Catholics, namely, Nicholas Fairfax and James Barefoot."

The course which was pursued by the royagers was, as we have stated, by the Azores and Barbadoes. They landed at the latter place on the 5 th of January, 1634, new style. Here, Father White says that the governor and inhabitants, who were English, endeavored to extort unreasonable prices for provisions and other necessary articles. One exception was made in potatoes, which were so abundant that they received a wagon-load as a present. The slaves, at that time upon the isiand, were in a state of rebellion, and had determined to take possession of the first vessel that should arrive. But their plot being discovered, the ringleaders were taken aud executed. As "The Ark" was the $3 \%$ 
first vessel that arrived, she was the doomed prize; and on the very day that her company landed, eighty men, whom they found under arms, prevented the slaves from executing their designs. Leaving Barbadoes they passed St. Lucia, Guadaloupe, Montserrat, to St. Christopher's, where they spent ten days.

"Having, at length, weighed anchor hence," continues Father White, "we pursued our voyage until we reached a point, on the coast of Virginia, called 'Comfort,' on the 27th of February. We were in a good deal of dread from the unfriendliness of the English inhabitants of Virginia-to whom our colony had been an unwelcome theme. We brought, however, letters from the king, and the high constable of England, to the governor of the province, which contributed very much to appease their feelings, and to procure us future advantages. After receiving kind treatment for nine or ten days, we set sail, and on the $3 \mathrm{~d}$ of March, having arrived in the Chesapeake Bay, we tacked to the north to reach the Potomac river, to which we gave the name of St. Gregory. We called the point which stands on the south, St. Gregory ;* that on the north, St. Michacl's, $\uparrow$ in honor of the choir of angels. A larger and more 
beautiful stream I never have seen. The Thames, compared with it, is but a rivulet. Bounded on the sides with no marshes, it runs between solid and rising banks. On either side are splendid forests, not overgrown by weeds or briars; you might drive a four-horse carriage, with the reins loose in your hand, through them. We found the natives armed, at the very mouth of the river. That night fires were blazing throughout the country, and as they had never seen so large a ship as ours, messengers were sent around to announce the arrival of a canoe as large as an island, and numbering as many men as the trees in a forest. We passed on to the Heron Islands, so called from immense flocks of those birds. We touched at the first of them, which we called St. Clement's, on which, owing to its sloping banks, we could only land by fording. Here the maids, who had landed to wash the clothes, were almost drowned by the upsetting of the boat; I lost a large portion of my linen-no small loss in this part of the world. This island abounds in cedar-trees, sassafras, and all those herbs and flowers entering into the class of salads; and the walnut-tree, with a heavy shell, and a small, but very delicious kernel. A scope of four hundred acres did not appear sufficient for our new plantation. We desired a place which might preclude the commerce of the river to strangers, and also 
the possibility of their infringing on our boundaries. This was the most narrow crossing of the river. On the day of the Arinunciation of the B. V. Mary (25th of March), we first offered the sacrifice of the mass, never before done in this region of the world. After which, having raised on our shoulders an immense cross, which we had fashioned from a tree, and going in a procession to the designated spot, assisted by the governor, * commissary, and other Catholics, we erected the trophy of Christ the Saviour, and humbly bent the knee in reverence during the devout recitation of the litany of the holy cross. Our governor, however, having understood that the great chief of Piscataway was obeyed by many petty chiefs, determined to visit him, to explain the oljects of our coming, that, having conciliated his good-will our settlement might be more favorably regarded by the rest. Having, therefore, joined to our pinnace another, which he had procured in Virginia, and leaving the ship at anchor off St. Clements, retracing his course, he sailed up the southern bank of the river. Finding the savages had fled into the interior, he proceeded to the villagre, which, taking its name from the river, is yet called Potomac. Here he found Archihu, the uncle and tutor of the king, who was yet a boy.

- Leonard Calvert. 
The regency was in prudent and experienced hands. Father Altham who accompanied the gorernor (for I was detained with the baggage), explained, by means of an interpreter, the truths of the Christian religion. The chief listened to him willingly, after acknowledging his own faults. Being informed that no hostile motives had brought us among them, but that feelings of benevolence prompted us to impart to them the advantages of civilization, and to open the path of heaven to them, and to the more distant regions, he expressed himself not only well satisfied, but very grateful at our arrival. The interpreter was from the Protestants of Virginia. As the father could not explain every thing at once, he promised to return in a short time. 'I think,' said Archihu, "that we should all eat of the same table; my young men will visit the hunting-grounds for you, and all things shall be in common with us.' From hence we went to Piscataway; where all immediately flew to arms. About one hundred armed men with bows, were drawn up with their chief at their head. On learning our pacific intentions, laying aside his fears, the chief stepped into the pinnace, and on understanding our benevolent views in their regard, gave us liberty to settle in any part of his kingdom we might select. In the mean time, while the governor was on his journey to the emperor, the savages at St. Clement's becoming more 
bold, mixed familiarly with our sentries. We were accustomed to keep up a patrol day and night, to protect our woodeutters and our vessel, which was now undergoing repairs, from any sudden attack. The natives expressed their surprise at the size of our vessel, and wondered what part of the earth produced a tree large enongh to make such a boat. For they thought that it, like an Indian canoe, was hewn out of the trunk of a single tree. The report of our cannon struck them dumb with fear."

To his surprise, Calvert discovered here an Englishman, Captain Henry Fleet, who had become so enamored of the customs and modes of life of these uncivilized creatures, that he had resided among them for several years. During this period he seems to have conducted himself with so much discretion, as to have secured the general respect and confidence of his adopted friends.

The governor invited the chief of this people to visit him on board his vessel. He, at first, was unwilling to place himself so far in the power of these pale-faced strangers, but through the intercession of Captain Fleet, he finally consented. This shows that he placed considerable reliance upon the judgment and fidelity of Fleet. Otherwise he would not have committed himself into the han ls of Fleet's countryman.

Although the king of England, by charter, had 
granted this country to Lord Baltimore and his company, yet his brother, whom we have seen he appointed governor, did not regard this as extinguishing the rights of the original inhabitants. Hence, one of the first questions he asked of this native lord of the soil was, whether he would consent to the English settling in his territory in case they found a locality that pleased them. The chief discreetly answered, "I will not bid you go, neither will I bid you stay, but you may use your own discretion." By this shrewd, non-committal, reply he threw the whole responsibility of their decision and course of action upon the English themselves.

As the chief remained on board the boat longer than his followers expected, they began to fear that he was detained there against his will, or that, perhaps, he was slain. They therefore came down to the shore in large numbers to ascertain the facts. As the chief was out of sight, their fears were in creased, and nothing would pacify them, until he made his appearance.

As it seemed to the governor undesirable to attempt the establishment of a colony so far up the river, he retraced his course to St. Clement's Island. He was accompanied on his return by Captain Fleet.

He next proceeded to a small river which emp- 
tied into the Potomac on the north side, and which Calvert named St. George's, but which has since received the more permanent name of St. Mary's River. After sailing up this stream about twelve miles, he came to an Indian town, known in the native dialect as Yoamaco. It was inhabited by a tribe called, from the name of their city, Yoamacoes. As these Indians had experienced much trouble from their more powerful neighbors, the Susquehannas, they were contemplating a removal to a place where they hoped to be secure from their encroachments. Indeed, some had already left for that purpose. In a few days all the wigwams which composed the town would be forsaken.

After Calrert landed, he frankly informed the Werowance, as the chief was called, that he was in search of a suitable place to establish a colony, and asked him his opinion. The Werowance manifested the usual Indian characteristic-taciturnity-and said but little. He, probably, did not want these strangers to settle there, and at the same time did not wish to offend them by an expression of his feelings. He, however, gave a hospitable reception to the governor ; invited him into his cabin; entertained him kindly, and at night relinquished to him his own bed to sleep on. It is not mlikely that by the interview, a favorable impression was made 
upon the mind of the chief, for the next day he voluntarily showed Calvert the country, who determined to select this as the place of his first settlement. After coming to this decision, it was his policy to pursue such a course as to gain the consent of the Werowance and his followers. He, therefore, manifested toward them the greatest friendship. To the chief, and some of his principal braves and counselors he made presents of English cloth, axes, hoes and knives. As these were articles which they could not make, and were yet of great service, they accepted them with evident marks of pleasure.

The consequence of this friendly manifestation on the part of the English was, that they secured the consent of the Indians to take up their residence among them immediately; and, to furnish them with something like suitable accommodations, they cheerfully offered to vacate the huts in one part of the town for their present use, with the promise, that so soon as they had harrested their corn, they would relinquish to them the whole town. It was further agreed upon, that until that time, the two parties should live together on terms of friendship, and that each nation should make suitable amends for any injury which any of their own people might inflict upon the other's.

After this treaty was agreed upon, Calvert sent 4 
orders to the men who were in his ships and boats, which had probably remained at St. Clements, to come to him; and on the 27th of March, 1634, they disembarked, and took possession of the town, to which they gave the name of St. Mary's. 


\section{CHAPTER II.}

A favorable Circumstance-First Buildings erected-An Indian honored-

The Honor misunderstood-A Gala-day-Imposing CeremoniesWhites and Indians living together-Nature of the Soil-Prepared for Planting-Clayborne's Conduct-He is frustrated-He is conquered, and sent to England-His Deception there-His Trial and its Results Clayborne and Ingle-Governor Calvert flees-Disorder prevailsRecords lost-Session of the Assembly-Governor Hill-Peculiarities.

IT was an extremely favorable circumstance for Calvert's colony that the Yoamacoes were on the eve of abandoning their town, at the time of their arrival, as it furnished them with dwellings of quite a comfortable character, which they might occupy until they could erect others more congenial to their tastes, and better suited to their wants. They answered, at least, for a shelter from the heat, and a covert from the storm. Far different had it been with the colonies of Virginia and Massachusetts. If the Puritans who landed on Plymouth Rock, had been so successful as to have found empty dwellings ready for their reception, they would have regarded it as a special providence: and it would have been in perfect keeping with their habits, if they had kept a day of special thanksgiving for so great a 
mercy. The incident would have been held in constant remembrance, by their descendants, and repeated, at least yearly, in some of their many addresses on the life and labors of their ancestors.

After the landing of the colonists at St: Mary's, they proceeded immediately to the erection of two buildings, in one of which to store their food and merchandise, and the other to use as a fort for defense.

They had not been there long before they were favored with a friendly visit from Sir John Harvey, the governor of the infant colonies of Virginia. This seems to intimate that he did not sympathize very strongly with the opposition which had been made by some of the Virginians to Calvert's settling in Maryland. During Harvey's stay at St. Mary's, Calvert was visited by several Indian chiefs, among whom was the Werowance of Patuxent, who had previonsly passed some time in imprisonment among the English in Virginia. For the gratification of these chiefs, Calvert gave an entertainment on board the ship.

In the arrangements at dinner, a seat of honor was assigned to the Patuxent chief at the table, between the governors of Maryland and Virginia. If this had been understood, it would have been regarded as a mark of great distinction, and would have afforded a high degree of satisfaction to the 
natives. But the design of the courtesy was strangely misunderstood, and came near converting this social entertainment, into a painful tragedy. One of the Patuxent Indians, who came on board the ship, as he looked in the cabin, and saw his chief placed between the two governors, received the impression that he was detained there as a prisoner, and carefully guarded, by the English. . He was so incensed at this supposed treason, that he not only refused to enter the cabin, but would have plunged overboard to escape similar treatment himself, if the chief had not. left his position, come on deck, and convinced him of his mistake.

When the store-house was completed, and it became necessary to remove the cargo from the vessel into the newly-erected building, the governor thought it desirable that it should be done with as much of pomp and public parade as they could display, in order to excite the surprise, and secure the respect and reverence of the savages. Accordingly the occasion was converted into a kind of gala-day. The flags were brought ashore, to wave their rich and variegated colors in the flashing sun-light. The guns were taken from the armory of the ressel, for the equipment of the men. The colonists were drawn up in military array. The two chiefs of Patuxent and Yoamaco, with many other natives, occupied favorable positions for hearing and seeing $4 *$ 
every thing that was said and done. All things being ready, the word of command was given, and immediately the musketry poured forth a volley, which fell upon the ears of the wondering savages, like the crashing of a forest before the blast. Scarcely had the sound died away, before the vessel in the river was seen to pour forth from the holes in her sides, streams of fire and smoke, accompanied with reports like thunder. This being done repeatedly, was adapted to impress the Indians with the wonderful knowledge and power of the white men, and probably accomplished the object which Calvert had in view. The Patuxent chief, who, during his imprisonment among the English, had probably witnessed other exhibitions of their skill and power, took this occasion to advise the Yoamaco Indians to keep on good terms with them, and by all means not to violate their treaty of amity.

This chief remained at St. Mary's several days, and it is reported that, when he left the governor, he made this remarkable speech: "I love the English so well that if they should go about to kill me, if I had breath enough to speak, I would command the people not to revenge my death, for I know they would not do such a thing except it were through my own fuult."

So judicious was the policy of Calvert in his 
treatment of the Indians, that he secured their confidence, so that during the remainder of the year, the two nations lived together in the greatest harmony. They joined each other in the chase, and when the Indians were more successful in hunting or fishing than the English, they readily parted with their game for some trifling articles, as knives or beads, and in this manner kept their new visitors well supplied with fiesh food. They even went so far in the exhibition of their confidence in these white strangers, as to allow their women aud children to labor as domestics in their families. The women taught them how to make bread of their corn, and the men instructed them in the different modes of taking deer and turkeys.

It was a fortunate circumstance that the emigrants arrived in America so early in the season. The severity of the winter was over, and all the changes which took place in the advance of the season, were of an agreeable character and indicated the approach of spring. Another favorable feature was, that the land in the neighborhood of the village had been cultivated by the Indians. It was not, therefore, in its wild and rugged condition, but broken up and soft, so that when the time for planting arrived, the soil was found to be in a com. paratively prepared state; ready for the reception of seed. This saved the colonists the trouble of 
cutting down trees, removing stones, and effecting a clearance before they commenced planting, as all this had been done.

Such was the fertility of the soil that the year following their exports of Indian corn are said to have amounted to ten thousand bushels. This was exchanged with the colonies of New England for salt fish, and other provisions.

The pleasant state of harmony between the English and the Indians was interrupted. One William Clayborne, who had been opposed to Calvert's establishing a settlement in Maryland, had formed a trading post, or colony, on the Isle of Kent in the Chesapeake river, and within the boundaries of Lord Baltimore's domain. He, also, had the nucleus of a settlement at the mouth of the Susquehanna. He had done all this under the protection of a license to trade with the natives; and even went so far as to claim the land in the vicinity of his settlements. When, therefore, Lord Baltimore obtained from the king a grant of land which included what Clayborne had called his property, the latter was offended, and was determined to create all the annoyance in his power.

When Lord Baltimore was informed of the facts in the case, he issued orders that if Clayborne would not submit to his authority he should be punished. The attempt to seize him, however, proved unsuo- 
cessful. To impede the prosperity of the colony at St. Mary's, Clayborne endeavored to excite the Indians against it. For this purpose he told them that these newly arrived emigrants were Spaniards, enemies to the English in Virginia, and presented other motives for the natives to attack and dive them off. At first the simple-minded aborigines believed him, and at once discontinued their intercourse with the settlement of St. Mary's. Their departure and change of conduct awakened the suspicions of Calrert and his company that some evil was contem. plated. They, therefore, relinquished work upon their own dwellings, which were then in process of erection, and combined all their efforts upon the fort, which, in the course of six weeks, they completed. After having provided this important means of defense, they returned to their own edifices and finished them.

Such was the judicious conduct of the English; so careful were they to aroid all conduct which might awaken the suspicions of the natives, and, so constant were they in giving every exhibition of friendliness when they occasionally met them, that it was not long before the Indians were convinced that the statements made by Clayborne were false, and returned again to their accustomed intercourse with the whites.

STo deepseated was Clayborne's opposition to the 
colony, that he was not discouraged by this failure to excite the Inclians against it, but resorted to other and more flagrant measures. In 1635 he gave a commission to one of his adherents, named Ratcliffe Warren, to capture any of the ressels which belonged to the emigrants at St. Mary's; and to aid lim in the execution of this object, he furnished him with a pinnace which carried a complement of about fourteen men, over whom Thomas Smith was second in command.

In anticipation of a collision; Gorernor Calvert prepared two boats for the emergeney, which he properly armed and manned and placed under the control of Thomas Cornwallis, Esq.

It is difficult for vessels belonging to opposing parties, to float in the same waters, with a knowledge of each others proximity, without soon finding an occasion to derelop their belligerent designs. That was the case in the present instance. When the parties met, which was in the month of April, in one of the rivers of Maryland, Clayborne's men opened their fire upon the boats of Cornwallis. Scarcely had the echoes from the shore died away before the insult was resented by the guns of Cornwallis. The engagement, which was probably of short duration, resulted in the death of one of Cornwallis's men, and two of Clayborne's, and in the capture of the boat and whole party of the latter. It 
was now an easy task for the conquerors to take possession of the Isle of Kent, on which was Clayborne's settlement.

Clayborne, fearing the threats of Calvert, fled to Virginia and sought shelter under the protection of Governor Harvey. Calvert sent to Virginia to reclaim him as a fugitive from justice; but Harvey considered it best to send him to England for trial, accompanied by the witnesses in the case.

After his flight, the colonial assembly of Maryland passed an act of attainder against him and seized his estates.

When Clayborne arrived in England he attempted to seek redress for his wrongs. By misrepresentations and the influence of powerful friends, he succeeded, for a brief period, in obtaining the favorable consideration of the King. But when the whole matter was examined by the commissioners for the plantations, they sustained the claims of Lord Baltimore, and decided that he possessed the exclusive authority to establish, or permit others to establish settlements, or open commerce with the Indians within the limits of Maryland.

Clayborne had been encouraged and assisted in his rebellion by Captain Richard Ingle, who had been arrested upon a charge of treason, but had managed to escape from the authorities. At a later perior, under the impulse of revenge for what 
they deemed the wrongs which they-had received from Lord Baltimore, Clayborne and his party came upon St. Mary's and compelled Governor Calvert to flee, who was glad to find a refuge from them in the colony of Virginia. The insurgents now had every thing in their own way and the resuit was that disorder and misrule prevailed. Their dominion, however, was of short duration, lasting only a little longer than a year. They managed, however, among other ruinous deeds, to lose, or destroy almost all the early records of the colony.

How the affairs of the colony were managed during the period of Ingle's and Clayborne's rebellion, and what particular incidents occurred, it is now impossible to tell. By the loss of the records, to which allusion has just been made, we have been deprived of authentic documents upon the subject; and cotemporary writers, it appears, did not regard the events which transpired of sufficient importance to make them the subjects of historical narrative.

During Calvert's absence from Marylaṇd, a Mr. Hill was chosen governor; but when at the latter part of the year 1646, Calvert returned with a little army which he had managed to collect in Virginia the insurgents, after some slight engagements, submitted to him. Mr. Hill "the pretended governor" was compelled to relinquish his office, but 
this was done upon certain conditions to which he and Calvert mutually subscribed.

The first session of the assembly of Maryland which was held after Goyernor Calvert's restoration to authority, exhibited two remarkable peculiarities. During Governor Hill's equivocal administration he called an assembly of the province which, after passing some laws (now unknown), adjourned. After Calvert's reinstatement to office he convened the same assembly again.

It appears to us remarkable that Calvert could have had sufficient confidence in an assembly which had been called by Hill during the rebellion (and who are said to have consisted, with two or three exceptions, of Calvert's enemies) to trust them with the power of enacting laws for the colony. If, however, we were acquainted with all the circumstances, it might be seen that this was an eminently judicious, pacific movement, and was directly adopted to bring back those insurgents, who had been led astray by Clayborne, to a firmadhesion to Calvert's government. The other peculiarity was that at this session of the assembly we have the first instance recorded of the distinction between the upper and lower houses of assembly " and the form practiced of sending for the lower house to attend the gorernor in the upper, to hear his speech to them in the manner of an English legislative body." 


\section{CHAPTER III.}

Colonists to scatter--Foresight of Lord Baltimore-Conditions of Landgrants-Special Instructions-Courts Baron and Courts Leet-New Uses -Remnant of the Feudal Ages-Manors of Lands-Important Feature-Failure of the Aristocratic Element a Cause of Thanksgiving.

In will be appropriate here to consider, on what terms grants of lands were made by Lord Baltimore to individual colonists.

It was not expected, when the enterprise of settling Naryland was first commenced, that all the colonists would establish themselves in one place, but that as they gathered strength, and secured the good will of the Indians, they would scatter themselves throughout the region. The intelligent foresight of Lord Baltimore induced him to make provision for this, by holding out inducements for the people to emigrate and disperse over the country.

In the year 1636 he anthorized his brother, the acting governor of the provinee, to make liberal grants of land to those already in the country, and then "to every other adventurer which shall transport any number of persons less than five, a grant of one hundred acres of land for him or herself, and one hundred more for his wife (if he brought any), 
and as much for every man-servant, and fifty acres more for every child under the age of sixteen years; and for every maid-servant under the age of forty years, to his or her heirs, forever, for the yearly rent of twelve pence for every fifty acres."

Other instructions which were given had a strong tendency to create a permanent aristocracy, which would have entailed a perpetual curse upon the land. They were as follows:-every one, two, or three thousand acres thus granted was to be erected into a manor, and named as the adventurer holding it should please.

"And we do further authorize you that you cause to be granted unto every of the said adventurers, within every of the said manors respectively, and to his or their heirs a court baron and court leet, to be from time to time held within every such manor respectively."

These courts baron and courts leet were courts of which the baron, and sometimes his steward, were the judges for the trial of civil cases.

Howerer repugnant such manors, with their courts and privileges, are to our republican views of the present day, it is evident that at that time they furnished a strong inducement for gentlemen of property in England, to emigrate with their families and adherents to Maryland, as they would be exalted to a baronetcy, with power to hold these feudal courts. 
One feature in these grants of land of a highly important character, was, that they were to be of an "indefeasible estate of inheritance in fee simple, to them and their heirs, forever." That is to say, the conditions on which the lands were originally granted to the adventurers were never to be altered, but were to descend to their heirs forever, on the same conditions. So that the grant of one thousand acres of land for the yearly rent of twenty shillings, to be paid in the commodities, was to remain the same forever. The rent could never be increased. No matter how greatly the value of the land might rise, nor how large might be the income accruing to the tenant or baron who held it, this rent of twenty shillings could never be increased. This was the English meaning of fee simple.

It is easy to perceive that this was a remnant of the customs which prevailed in the feudal ages, when a king, or great lord granted to noblemen or military officers, for a nominal annuity, a large extent of territory to govern, and from which to derive a revenue for their own benefit.

In accordance with the instructions which he gave to the Governor of Maryland, Lord Baltimore laid off, in different parts of the province, manors of lands, some of which were reserved for his own use, others for the benefit of his relatives and friends, and others for any individuals who would 
receive them according to the specified conditions.

But although this attempt to fasten an odious, aristocratic, and feudal element upon our soil, was thus made in the first settlement of the country, it should be a matter of sincere thanksgiving that it proved a failure. If courts baron or courts leet were ever held in Maryland, the records of them have perished. It is certain that if they were held at all, it must have been but very seldom.

$5 *$ 


\section{CHAPTER IV.}

Erroneous Inferences-Religious Liberty- When it is defective-Charter and Laws of Maryland-Conformity to the Ecclesiastical Laws of England-Union of Religion and Civil Government-Religious Toleration -Reproachful Terms forbidden-Penalty for using them-Liberty limited-Oppressive Laws-The Difference in Rhode Island-Influence of Protestantism-Liberal Principles.

Some writers upon the history of our country have used such strong and glowing language respecting the religious liberty of the young Catholic colony of Maryland as is liable to convey an erroneous impression. And inferences have been drawn from it to show that one of the glorious features of Roman Catholicism is its toleration of all religious sects!!

A mere reference to Ireland, Italy, Spain or Portugal, when under the dominion of the papacy, would be a sufficient refutation to such an inference. But, as a sober argument to establish this false position is attempted to be made out of the proceedings of the colony of Maryland, it is appropriate that the facts should here be stated.

Religious liberty, or the toleration of all religious 
sects, is that element of civil gorernment which allows every person to form any opinion upon religious subjects, and practice any religious ceremonies, he pleases, prorided he does not interfere with the rights of others. The attempt, by any legal enactments, to bring about a uniformity of belief and practice-to fine, imprison, or otherwise punish men for their religious belief, is tyranny. In the degree in which these coercive measures are adopted in any government, is the element of religious liberty defective. Let us see now what were the facts upon this subject in the early history of Maryland.

If we turn to the charter, we find that the fourth paragraph, or section, grants to Lord Baltimore and his heirs, authority to erect and found "churches, chapels, and places of worship, in convenient and suitable places within the premises, and of causing the same to be dedicated and consecrated accorcling to the ecclesiastical law of our kingdom of England."

From that it would seem that the extent in which religious liberty could be enjoyed, in accordance with the precise construction of the charter, was the degree in which it existed in the mother country. The phrase which we have italicised above, fixed its limits.

In the twenty-second section it was provided 
that no interpretation of the charter should "be made whereby God's holy and true Christian relig. ion, or the allegiance due to us, our heirs, and successors, may in anyzise sutier by change, prejudice, or diminution."

While, therefore, the charter, in respect to its phraseology, grants protection to the Christian religion, it attempts no definition of what that religion is. It might be inferred from the fourth section, that it meant the Christian religion as settled by "the ecclesiastical laws of England."

If we leave the charter and pass on to some of the early laws which were enacted upon this sub. ject, we shall discorer the opinions and policy of the colonists themselves.

At a meeting of the General Assembly of Maryland, held in 1649, a law was passed entitled "An act concerning religion," the preamble of which states, "Forasmuch as in a well-gorerned and Christian commonwealth, matters concerning religrion and the honor of God ought, in the first place to be taken into serious consideration and endeavored to be settlen, be it therefore ordained, etc."

This preamble assumes the right of the Legislature to settle, by legal enactments, the religious institutions of the land; to decide what opinions and practices shall be, and what shall not be, tolerated; 
it thus goes the whole length of admitting the constitutionality of the connection between Church and State-the power of the Legislature to erect, by legal enactments, an established religion. Although this principle is now repudiated in the United States, being regarded there as the bane of nations, fraught with alnost every kind and degree of political evil, yet at the period of which we treat, it was not peculiar to Maryland. It was generally adopted. It was in practical operation in Virginia, in Massachusetts, in England, and the other governments of Europe. So important was the connection between the government and the Church at that time considered, that one of the first duties of the government was supposed to be the protection of the interests of the Church, and therefore this is expressly stated in the above prearnble.

Although this preamble admits the right of the Legislature to settle "matters concerning religion," yet the law to which it was the introduction, was an exceedingly liberal one, and granted liberty of conscience to all persons "professing to believe in Jesus Christ." Its language is, "Whereas the enforcing of the conscience in matters of religion, hath frequently fallen out to be of dangerous consequence in those commonwealths where it has been practiced, and for the more quiet and peaceable government of this province, and the better to pre- 
serve mutual love and unity among the inhabitants here, be it therefore also, by the lord proprietary, with the advice and assent of this assembly; ordained and enacted * * * that no person or persons, within this province *** professing to believe in Jesus Christ, shall from henceforth be anywise troubled, molested, or discountenanced for, or in respect of, his or her religion, nor in the free exercise thereof, within this province * * * nor any way compelled to the belief, or exercise of any other religion, against his or her consent."

It was also enacted that any person who should violate this law by troubling or molesting others, either in person or estate, on account of their religion, should be compelled to pay treble damages to the party so injured, and for every such offense should, in addition, forfeit twenty shillings sterling.

This was a very liberal provision, and was far in advance of any other government, with the exception of the small, but free and independent, colony of Providence.

The object of Lord Baltimore was to increase the number of settlers in Maryland. To accomplish this he adopted a wise policy. Religious persecution was the fashion of the times. Catholics, Puritans, and all other sects, except those belonging to the Established Church, were subjected to great 
disabilities in England in consequence of their religious tenets; while in the Roman Catholic countries of Europe, all, except the adherents of the papacy, were the objects of ecclesiastical censure, and criminal prosecution. Liberty to think and act for oneself in religious matters, was nowhere allowed in Europe. The establishment of a colony, therefore, where unfettered freedom of conscience was to be guarantied to all the colonists, must have appeared like a bright spot in the horizon, to the various persecuted sects in the Old World, and must have furnished them with a strong inducement to emigrate, that they might enjoy the peace which was denied them in their own lands.

So minute in its details was the law that was passed in Maryland as to be almost a violation of its own fundamental principle. For instance, it enacted that any person who should, upon any uccasion, declare, or call by way of reproach, any other person residing in the province, a Heretic, Schismatic, Idolator, Puritan, Presbyterian, Independent, Popish Priest, Jesuit, Jesuited Papist, Lutheran, Calvinist, Anabaptist, Brownist, Antinomian, Barrowist, Round-head, Separatist, or other name or term, in a reproachful manner, relating to religion, should, for every such offense, be fined ten shillings sterling. If he had not property sufficient to pay this fine, he was then to be publicly 
whipped, and then suffer imprisonment until he should satisfy the offended person by asking his or her forgiveness publicly, in the presence of the officers or chief magistrate of the town where the offense was committed.

A law like this would, at the present day, be regarded as a great infringement upon liberty of speech. Many of these forbidden terms were used as descriptive epithets and saved a circumlocution. They could be used therefore without the exhibition of any disrespect whatever. It is evident also that the execution of the law would involve great difficulty, for how could it be satisfactorily settled in any given instance, whether these terms were used reproachfully or merely as explanatory-as simply descriptive of the parties intended?

Still, the law, taken as a whole, appears to exhibit the determination of the colony to protect all individuals from insult and injury on account of their religious opinions. It seems, upon a cursory glance, to offer universal religious toleration. But a more careful examination of its provisions will convince us that this is not the case.

In the first place, those to whom toleration was offered were those "professing to believe in Jesus Christ." Consequently all who came not within this description were excluded. Jews, Mohammedans, IIndoos, ete., would not have been allowed the 
unmolested enjoyment of their religious viems, if they had been disposed to reside there. Even the Indians, the original owners of the soil, were not protected by this law in their religion. It was very far therefore from granting universal religious liberty.

In the next place, when we ascertain who are meant by "those professing to believe in Jesus Christ," we shall discorer another" great contraction in the liberty granted by this law, which would throw without the pale of its protection thousands of individuals who, at the present day, profess to be believers in Christ. It was designed as descriptive of those who are generally known as "evangelical" or "orthodox" in their belief-those who hold to the Supreme Divinity of Christ, and the trinity of persons in the Godhead. All such sects had liberty of conscience granted them. But believers in what is now termed Unitarianism, were not only not tolerated, but were subjected to the sererest penalty that could be executed. For the law enacted that "any person or persons, within this prorince, that shall deny our Saviour Jesus Christ to be the Son of God, or shall deny the Holy Trinity, the Father, Son, and Holy Ghost, or the Godhead of any of the said three persons of the Trinity, or the Unity of the Godhead, or shall use or utter any reproachful speeches, words or language concerning the Holy 
Trinity, or any of the said three persons thereof, shall be punished with death, and confiscation, or forfeiture of all his or her lands and goods"!!

It is a very remarkable circumstance that while, in the Puritan colonies of Massachusetts, Episcopalians and other sects were not tolerated, and in the Episcopalian settlement in Virginia, Puritans and others were not allowed a peaceful residence, yet in the Catholic colony of Maryland, Episcopalians and Puritaus were both permitted the enjoyment of freedom of conscience though the same law that granted them that boon doomed every Unitarian to death !*

In the same statute it was also enacted that whoever should utter any reproachful words concerning the "blessed Virgin Mary," or any of the apostles or evangelists, should be fined five pounds sterling, and if he was too poor to pay the fine, he was to be whipped and afterward imprisoned during the pleasure of the lord proprietary, or the governor of the province. For the second offense he was to pay a fine of ten pounds sterling, or, as a substitute, to be "publicly and severely whipped," and for the third oflense he was to forfeit all his lands and goods and be forever banished from the colony.

In this law there was a strange blending of the

* This law, it is said, still exists in Maryland. 
elements of religious liberty and spiritual despotism. And how a legislative body which approved of one part of its provisions, could favor another part, is "passing strange." Yet, with all its imperfections, it was on the whole a very liberal enactment, when compared with those of the colonies of Plymouth, Massachusetts, and Jamestown. It granted more religious freedom than could be enjoyed under any monarchy in Europe. Its spirit of toleration was excelled nowhere upon earth, except by the plantations at Rhode Island, where at the first meeting of their General Assembly, held in May, 1647, a code of ciril regulations was passed, which concluded as follows: "Otherwise than thus, what is herein forbidden, all men may walk as their consciences persuade them, every one in the name of his God. And let the lambs of the Most High walk in this colony without molestation, in the uame of Jehovah, their God, forerer and ever."

Some time prior to this, it had been decided by the authorities of the town of Providence, that all persons who settled there should sign a document, in which they promised to submit themselres in active or passive obedience to all such orders or agreements as should be regularly adopted by a majority of the inhabitants, but "only in civil things." This left their religious opinions and practices untouched. 
While, therefore, in Maryland, religious toleration was granted to those only who professed to believe in the divinity of Jesus Christ, and in the trinity of persons in the Godhead (the deniers of these sentiments being doomed to death), in Phode Island every complexion of religious faith was allowed. Jews and Christians, Miohammedans and Pagans, were alike guarantied the unmolested enjoyment. of their religious opinions and practices. None were subjected to any civil disabilities, or other penalty, on account of their faith. Conduct, and not opinions, was there regarded as the only appropriate subject of legal adjudication. A man might believe and practice what he chose, provided he did not trespass upon the rights of others. The widest religious liberty was granted that was consistent with public order, and therefore, as Gorernor Hopkins has said, "Roger Williams justly claims the honor of having been the first legislator in the world, in its latter ages, that fully and effectually provided for, and established a full, fiee, and absolute liberty of conscience."

Notwithstanding the limitations of the law of Maryland, if it should excite any surprise that a statute so liberal on the whole should have been passed there, that astonishment will be lessened when it is known that in the Provincial Assembly were many Protestants. Bozman in his History of 
Maryland, states that " there are strong grounds to believe that the majority of the members of this Assembly of 1649 were Protestants. * * * Governor Stone and a majority of the Council were Protestants. There are strong reasons for a supposition that a majority of the members of the other House of Assembly were Protestants also; inasmuch as they certainly were at the next session of 1650. We may then fairly presume that the governor and council sitting with the lower house at this session (for they were not yet divided into two houses, as at the next session) made as majority of Protestants. The acts of this Assembly, therefore, were the legislative proceedings of Protestants."

The fact that this law was approved by Lord Baltimore, who was a Roman Catholic, although it was a wide departure from the established usages of Roman Catholic governments elsewhere, furnishes evidence that he was a man of liberal.principles, and for which he ought to receive all due praise. 6 \% 


\section{CHAPTER V.}

Law against Stealing One's-self-Arbitrary Distinctions-Influence of the Roman Catholic Priests-Importance of little Knowledge-Peculiar Law-Curious Definition of Drunkenness-Its penalty-Law enjoining Fasting-Laws respecting Tobacco and Corn-Corn to be twice shakeu -Corn Hand-mills-Saw-mill clestroyed in I onclon-Reasons for Indiap Fears-Ancient Feuds among the Indians-Indian Opinions-Collision with the Indians-Warlike Preparations-The Maquantequats-Tho Patuxent Indians-They are reconciled and protected.

Is addition to the laws which are alluded to in the last chapter, there were a number of others, that were passed by the Assembly of Maryland, in her early history, that shed light upon the peculiar features of those times.

In 1639.it was enacted that "steculth of one's-self, which is the unlawful departure of a servant out of service, or out of the colony, without the privity or consent of the master or mistress," was to be punished with "the pains of death by hanging, except the offender can read clerk-like, and then he shall lose his hand, or be burned in the hand or forehear with a hot iron, and forfeit his lands, goods, and chattels." 'This forfeiture of property was to be complete (saving to the widow, her lower, and to 
the heirs, his or her inheritance, if claims be made thereof within three years after judgment is given). The same penalty was annexed to a ariety of other crimes, which, by the same law, were declared to be felonies, such as manslaughter, malicious trespass, cutting out another's tongue, forgery, assaulting the lieutenant-general, or beating or assaulting any judge, witness, or juryman in court.

It will, doubtless, appear to the reader somewhat singular that the extreme penalty of death could be escaped in these cases, provided the criminal "could read clerk-like." If two individuals were convicted of similar crimes, say forgery, manslaughter, or stealing himself, one of whom could read, and the other could not, the former would escape the gallows, but the other would be hung.

In accounting for this arbitrary distinction, Bozman states that the Roman Catholic clergy had obtained such great infiuence over most of the European nations, that they had secured for themselves an exemption fiom all punishments affixed to crimes, except such as were imposed by their own ecclesiastical tribunals. "This privilege originally annexed to their order by the ancient Church, was not abrogated in England by the Reformation. It had so interwoven itself with the common law of the realm, that a total abolition of even so odious an exemption becarne almost impossible." As, 
during the middle ages, the ignorance of the masses was so great that but few or any could read, except the clergy, the ability to read clerklike, or like a clergyman, was regarded as conclusive evidence that the reader belonged to the clerical profession, and was, therefore, entitled to exemption from all penalties, except those fixed by the Church. Hence the extraordinary question when about to pass sentence on a criminal, "Can he read, or not read?" This criterion was transported across the Atlantic, and was practiced in the early history of Maryland, so that an offender"s life was suspended upon the question, "Can he read or not?" This eminently unjust and offensive distinction, continued in use in Maryland till the commencement of the eighteenth century!!

It was also enacted that any one who should remove out of an English plantation to reside among any Indians not christened, without the consent of the colonial government, should be imprisoned.

Swearing, which is described as the "prophane adjuration by God, or some holy creature," should be fined five pounds of tobacco, or one shilling sterling.

Various nations have passed laws against drunkenness, but in not a few instances embarrassments have arisen in the execution of the law, arising from the 
difficulty of deciding whether the accused was really guilty or not. What is drunkenness, and to how great a degree must a person be intoxicated, before he be subjected to the penalty? are questions upon which there have always been different opinions.

In the enactment upon this subject passed by the Assembly of Maryland, an attempt was made to define the offense, as follows:- "Drunkenness, which is drinking with excess to the notable perturbation of" any organ of sense or motion" shall be punished with a fine of thirty pounds tobacco, or five shillings sterling, or otherwise the offender shall be whipped, or by some other corporal shame or punishment corrected for every such excess at the discretion of the judge.

Eating flesh in time of Lent, or on other days wherein it is prohibited by the law of England, except in case of sickness, or infirmity, was fined five pounds of tobacco or one shilling sterling for every such offense.

Corn was an essential article of existence in Maryland, and as there was danger that, if the Indians became at variance with the whites, they would withhold their grain, and, by so doing, subject the colonists to great distress, it was considered important to encourage the cultivation of this article; accordingly, it was enacted that "any person planting tobaces, was yearly, also, to plant and tend two 
acres of corn for his own food, and two acres of corn more for every person in his family planting tobacco, under the penalty of five barrels of corn or other commodities, to the value thereof, for every two acres of corn wherein he shall make default." By the faithful obserrance of this law, it was believed that they would be to a great degree, if not entirely, independent of the Indians for their supplies of grain.

Another law, which was passed at the same session, regrulated the manner of measuring this article, which will strike the uninitiated as somewhat peculiar;-it reads as follows: "And all contracts made for parment in corn, shall be understood of corn shelled; and a barrel of new corn tendered in payment at, or afore the fifteenth day of October in any year shall be ticice shaked in the barrel and afterward heaped as long as it ucill lie on; and at or before the feast of the nativity; shall be tucice shated and filled to the edge of the barrel, or else not shaked, and heaped as before; and after the said feast, it shall not be shaked at all, but delivered by strike."

Having obtained corn, the next thing was to grind it and convert it to meal. For this purpose small hand-mills were in use. But as this furnished a slow process fur proviling the requisite amount of meal, it was necesary that a large mill should be 
erectel. There being no men of capital amoug the colonists who were disposed to invest their money in a mill, as a business speculation, it was enacted that "Any bargain which the lieutenant-general and council shall make with any undertaker, for the setting up of a water mill for the use of this colony, shall be levied upon all inhabitants of the colony in such manner as the lieutenant-general and council shall appoint, so it exceed not ten thousand pounds tobacco in a year'for two years only." Thus the whole colony were taxed for funds to erect a watermill.

It is an interesting coincidence that the first watermill built in Massachusetts was not erected until after that colony had been in existence about as long as the colony of Maryland had been, when this mill was built; and the same year of the erection of the one in Massachusetts, which was 1633, a saw-mill is said to have been built near London, but as it was unpopular, being regarded as a machine which would deprive many of the poor of the employment by which they obtained a livelihood, it was destroyed, perhaps under the influence of mob-law.

Thus far the colony of Maryland had succeeded in keeping on such friendly terms with the Indians that there had been no serious outbreak between them. In this respect they had been more successful than the other Ameri san colonies. But about 
the year 1639 these pacific relations were ir ser. rupted.

The more thoughtful and experienced among the aborigines of Maryland and Virginia appeared to foresee their approaching doom, provided these white intruders upon their soil were allowed to increase.

To their untutored mind, the settlement and habits of these strangers must have been invested with great mystery. They were introduced among them in a surprising manner, coming as they did in great floating houses, with apparently many white wings which they could fold or open at pleasure; their pale color, their superior attainments in domestic life and manufactures, their miraculous weapons which breathed fire, spoke thunder, and sent invisible balls with resistless force; the fact, too, that they came fiom unknown lands beyond the sea, and might, for aught they knew, be exceedingly numerous-all these considerations served to impart, in their view, a deep tinge of the marvelous to the coming of these uninvited strangers, and must also have made them anxious to be relieved of their presence. Another thing which served to increase the unpopularity of the English, was their interference with the difficulties which existed between different native tribes, and their attempts to prevent wars between them. These tribes being 
composed of barbarous people, took delight in the excitements of war. Their code of morals not only justified but required revenge. Insult was not allowed to pass with impunity. Blood must be wiped out with blood. As there were ancient feuds existing between different tribes, whenever any of those tribes met, their erroneous motives of honor, patriotism, and religion, rendered it obligatory upon them to sound the startling war-whop, rush at once into bloody conflict, and destroy as many of their long-standing enemies as possible. They deemed themselves culpable, if they allowed them to escape without an effort for their destruction. It is evident that every such collision added to the previously existing causes of hatred between them, and increased the obligation of survivors to seek rerenge. Interference in these matters on the part of foreigners was peculiarly offensive to many of these wild knights of the arrow, the twang of whose bow-string, mingling with the shrieks of those to whom it had sent death, was the most grateful sound that fell upon their ears.

It was about this time, 1639 , that certain signs or dissatisfaction on the part of the Indians toward the whites began to be manifested. At this period alsô it is supposed those plots began to be formed which resulted in the dreadful massacre in Vir- 
ginia, * when the notorious chief Opechancanough secured the sudden slaughter of some hundreds of unsuspecting whites.

In Maryland the powerful Susquehanocks were at war with the Piscattoway and Patuxent Indians, and probably with the Yoamacoes. These three latter tribes were on friendly terms with the English. The colonists therefore sympathized with them in the conflict, and interested themselves to prevent the incursions of the Susquehanocks against them. . This of course was not agreeable to the Suisquehanocks who, Indian-like, would be disposed to suspect the English of taking sides with the enemy. Certain unknown Indians on the eastern shore were also hostile. The consequence was that the colony incurred the anger of the aggressive tribe, and became involved in the conflict.

All was now anxiety and excitement. At what point, in what manner, or at what time the murderous barbarians might come down upon the English like a destructive avalanche, was unknown. It was deemed best not to wait for them, but putting on a bold front and making an incursion upon their own soil, convince them that the English had no fear of the issue. It was accordingly ordered that a "shallop be sent to Virginia for to provide twenty

* An account of this massacre we have given in the "Nov. elties of the New World." 
corselets, * a barrel of powder, four roundlets of shot, a barrel of oatmeal, three firkins of butter, and four cases of hot waters; and that five able persons be pressed to go with the said shallop, and necessary prorisions of victuals be made for them." It was also ordered that a pinnace should be pressed to go to the Isle of Kent and provide four hogsheads of meal, and that another should be sent against the Susquehanocks, sufficiently victualed ani manned, and thirty or more good marksmen, with an adequate number of suitable officers; and that each marksman be allowed at the rate of a hundred pounds of tobacco per month, or another man in his place to take care of his plantation, and two sergeants who should receive double that rate. Two pinuaces and one skiff, if necessary, and good laboring hands be pressed to supply the places of such planters as shall be pressed upon the service, and be allowed at the same rate of one hundred pounds per month."

In addition to these arrangements for an aggressive movement, the colonists, and especially those at St. Mary's, were placed in a better state of defense. All the inhabitants of the colony able to bear arms were required to train that they might "learn the art and discipline of war."

What military operations against the Indians during the year were the results of these arrangements

* A corselet was a piece of armor or the front of the body. 
we are not informed, but from a commission which was issued next year to Nicholas Hervey, it seems that hostilities had not entirely ceased. For by this commission Hervey was authorized to go with not less than twelve men, well provided with arms, against the Maquantequats only and "execute and inflict what may be inflicted by the law of war." It woald appear from the limits of this commission to make war only on the Maquantequats, that friendly relations had been brought about between the English and the other tribes.

We know that this was the case with reference to the Patuxent Indians, because a proclamation was issued, bearing date January 24, 1639, which stated: "WVe are in peace and unity with the $\mathrm{Pa}$ tuxent Indians our neighbors, and have taken them into our protection, and therefore do prohibit all English whatsoever within our province of Maryland, for the time being, that they do not offer any injury or nutrage whatsoever, to any of the said Indians upon pain of such punishment as the offense shall deserve." 


\section{CHAPTER VI.}

Colonies multiplied-Captain Lucas Fox-His Toyage to the Northern Regions-Dangers from the Ice-How Icebergs are formed-Description of a Sea Unicorn-Variation of the Needie-Reasons for it-Geological Discorery-A White Bear floating upon Ice-Its pursuit and Capture-Petty Dancers-Hunting Swans and Seals-Graves discovered -Dog hunting a Stag-School of Whales-A Dun Fox-Remains of Captain Button's Dwellings-Going a Berrying-A Cross found-Seeking a Main-yard-The Maria met with-Fox names various Places-Fox's Return.

Wrille the events, which are narrated in the preceding chapters, were transpiring within the limits of Maryland, efforts were being made to push discoveries and establish settlements in other places on the North American coast. To some of the more important of these it is proper that we now refer.

Plymouth in New England was settled in 1620. Within a few years other settlements were formed in New England, as at Cape Ann, Salem, and Boston. Colonies had also been established at Jamestown and other places in Virginia. The old idea of a North-west passage to India was still cherished, and expeditions were sent out to confirm or explode its practicability. In 1631 the same year that Clayborne first planted himself upon the island of Kent 
in Maryland, an ent $t$ rprise was projected in England for explorations along the north-east coast of Amer. ica, with a view to the discovery of the famous Northern passage. It was placed under the direction of Lucas Fox, a seaman of great experience, of whom it might be said that for many years " his path was upon the mountain wave, his home upon the deep."

Being disappointed in 1606 in not going as mate with Captain John Knight upon a voyage of discovery to the north, as he had expected to, he, from that time, diligently collected all the information he could possibly obtain, by a careful perusal of all the royages which had been made to the northern frigid zone, and from conversations with men who themselves had seen the ice mountains and felt the sub-zeroic cold of those frozen regions.

King Charles I., being informed of the contemplated royage of discovery, gracionsly added a ship of his own, which he fitted with necessaries, and manned-with able-bodied seamen in the most complete manner.

When Captain Fox was introduced into tne presence of his royal patron, his majesty kindly presented him with a map, or which were marked all the discoveries which had then been made. The decree of hope which the king entertained that Fox would make the discovery of the north-west passage may be inferred from his giving to him a 
letter to the Emperor of Japan, to be delivered in case he shonld reach the South Sea by the passage he was going out to discover.

All things being arranged under the most farorable circumstances, Captain Fox set sail from Deptford on the 5th of May, 1631, in a ship of only eighty tons burden, called, perhaps, after its royal owner, "The Charles." On the tenth day out, he had the misfortune to break his main-yard, which obliged him to put into the Orkneys for repairs. But being unable to procure a new main-yard there, he was compelled to continue his royage in this maimed condition. Passing Cape Farewell, the southern point of Greenland, he continued his course a little north of west, in order to reach Hudson's Straits. As he approached it he saw that the sea before him was dotted with islands, or large pieces of floating ice. He now had to redouble his vigilance to avoid coming in collision with them, as a comparatively slight blow of one of these huge masses would have been sufficient to dash a hole in the ressel and sink her to the bottom. After groping his way through the floating ice as well as he was able, for a number of days, his eyes were finally cheered with a distant view of terra-firma. It proved to be land on the north side of Lumley's Inlet, probably Cape Eliza. beth, the south-eastern point of the Island of Good Fortune. $\mathrm{He}$ was desirous of passing through 
Lumley's Inlet into Davis's Straits, but he found, although it was summer, so much ice as to make the attempt dangerous. He directed his course to the Button Islands, several small islands on the northern coast of Labrador. The morning of the 23d opened with a heavy fog, but in the middle of the day, the rays of the sun poured down with such power that not only was the surrounding ice converted rapidly into water, but the pitch on the sides of the ressel began also to melt-so sudden and great was the transition from cold to heat. This unusual warmth lasted, however, but a short time. The strait continued to be filled with immense quantities of ice of two kinds; first, mountainous, composed of large, irregular shaped masses, rising from sixty to a hundred and twenty feet above the surface of the water. When the rays of the sun shone upon them, they were extremely beautiful, presenting every variety of castelated appearance, and reflecting all the hues of the rainbow; the other was termed flaked ice, and consisted of thin flat cakes of every variety of shape and size, from a rood to several acres square. On the 30 th of June they passed by one of these flakes, on which was a quantity of earth and several stones, one of which weighing, as was supposed, five or six tons. An interesting question which has excited the attention of scientific men is, how are these ice-mountains 
inrmed? Their explanation as given by Mr. John Reinhold Foster is as follows: "These mountains of ice are formed on the shore, by the snow which the wind blows on to the steep brow of some high nountain, to which it adheres, and is compacted into a firm and solid piece of ice, which, in the spring, becomes loose at the approach of a thaw, and $\mathrm{l}^{\prime}$,lls into the sea, carrying with it the earth, stones, 1. uud and trees which it before enveloped." "One Is kght a mountain of ice came driving straight on toward the ship, as it was deeper under water than the flaked ice, the current consequently made it drive faster than the latter, some of which was betreen the ship and the mountain, else this huge mass, being already perforated by the action of the water upon it, in consequence of its percussion against the ship, might have burst; when the broken pieces falling into the vessel, might easily have sunk it, as this mountain was nine or ten f:thoms, that is from fifty-four to sixty feet above water, and who can say how much under it?"

On July 1st, Fox was opposite to another island near the Resolution Islands, which was called by some Terra Nivea. The weather was hot, sultry, and calm, a kind of dog-day. They could not start the vessel for want of wind. On the 4 th he sent some men ashore, who found several deserted huts which had been formerly occupied by natives, some 
Irittwood, and the fontprints of animals, supposed to be stags. On the 20th he came upon a quantity (f' sea unicorns, one of which was nine feet long, lack back, fiat tail, transverse with respect to the rldge, and indented between its two peaked ends, its sides were black and white dappled; its belly, white; the general shape of the body resembled a mackerel; its head like that of a lobster, on the firont of which was a wreathed horn, six feet long, entirely black, except a small portion at the tip.

On the 15th of July, Fox observed that the needle no longer pointed north.: It had lost its jower. He supposed that this phenomenon was caused by the metallic quality of neighboring mountains, or from the want of motion in the ship, or from the cold benumbing the needle as it benumbs sentient beings, or firom the sharpness of the air between the needle and its attractive point, by which the attractive force was neutralized. He was now in the latitude of sixty-three degrees and twelve minutes, near Nottingham Island.

He here made a discovery of considerable geological interest. He noticel that three neighboring islands which lay near the mouth of Hudson's Straits, called Resolution, Salisbury and Nottingham, were all of them high on their eastern, and low on their western side. "This physico-geographical observation," says Forster, "is of the 
highest importance, and seems to me to prove that at that time, when the sea burst impetuously into Hudson's Bay, and tore away these islands from the mainland, it must have come rushing from the east and south east, and have washed away the earth toward the west; a circumstance which has occasioned their present low position." If the reader will take the trouble to look on a map, and notice the general direction of Hudson's Straits, he will see that the above conjecture is not entirely unreasonable.

The same day that this discovery was made, the navigators saw many sea-horses. On the 18th, being near a part of the mainland known as Cary's Swan's Nest, a new object presented itself, which created a high degree of excitement among the men, and furnished them with considerable sport: this was a large white bear floating upon a cake of ice. All hands were soon either upon the deck or among the rigging, making their observations upon the appearance and behavior of this marine bruin. Presently it was proposed that they should endeavor to take him. Immediately the whole crew were in commotion, and impatient for the chase. All were anxious to share in the pleasure and the honor of taking this white-robed king of the north. This, however, was no easy task. Much time and maneuvering were spent before they succeeded in 
inflicting the fatal wound, and securing the victory. After dispatching the huge animal, their next business was to carre and dispose of it. This being done, they tried out its fat, and obtained from it forty-eight gallons of oil. Its flesh, when boiled, they fornd to be palatable, but when roasted it had a rank, fishy flavor.

In the evening of the same day, a dark streak girdled the horizon, and certain lights, or meteors, called the Henbanes or Petty Dancers, were seen flashing and waltzing at the north. These were regarded by Fox as the pioneers of a storm which would show itself within twenty-four hours. He was mistaken; that time passed away and no storm came.

When they arrived at Carey's Swan's Nest, they engaged in another kind of sport, which was the pursuit of swans. They were not, however, so successful with these as with the bear. As the place abounded with marshes, brooks and pools, with all of which the birds were fimiliar; as, too, the game was both shy and swift, the sportsmen, though they chased many, were unable to obtain one. On the 24 th a number of seals presented themselves. The 27 th was distinguished for the elevated temperature of the air. It was warm even in the night. An island was discovered on the west side of Hudson's Bay which they nancel sir 'Thomas Roe's Welcome. 
They discovered some grares of the natives, and formd in them spears headed with iron and copper. The next day the surface of the sea was broken in various directions by large numbers of tish leaping in the water. A whale and many seals were seen.

It was not long before Fox came to another island, which he described as a "white island," which he called after Sir John Brook, who was interested in the enterprise, Brook Cobham. It subsequently received the name of Marble Island. Swans, ducks and other aquatic birds abounded here in great numbers.

They had on board the ressel a dog: To gire him exercise and to use him in hunting, the quartermaster took him on shore, where he soon started a reindeer, and immediately took after it. The chase continued a long time, but finally, the dog brought the deer to a stand. The animal might then have been killed; but unfortunately the quarter-master had neither gun nor spear, and was therefore obliged to let him escape. So long and violent had been the pursuit, that the feet both of the deer and the dog were torn, and bled profusely. Near the island were a large school of whales lying so motionless, that Fox concluded they were asleep. For continued his course along the restern coast ofit the mainland, which was protected by many small dangerous rocks. On the 20 th* he visited a small island, on

* This is the date as giren by Forster. If the narratire was, 8 
which were many sea-fowl. Here he struck a seahorse, perhaps the walrus, with his lance, but it was too strong for him to capture alone, and so fled.

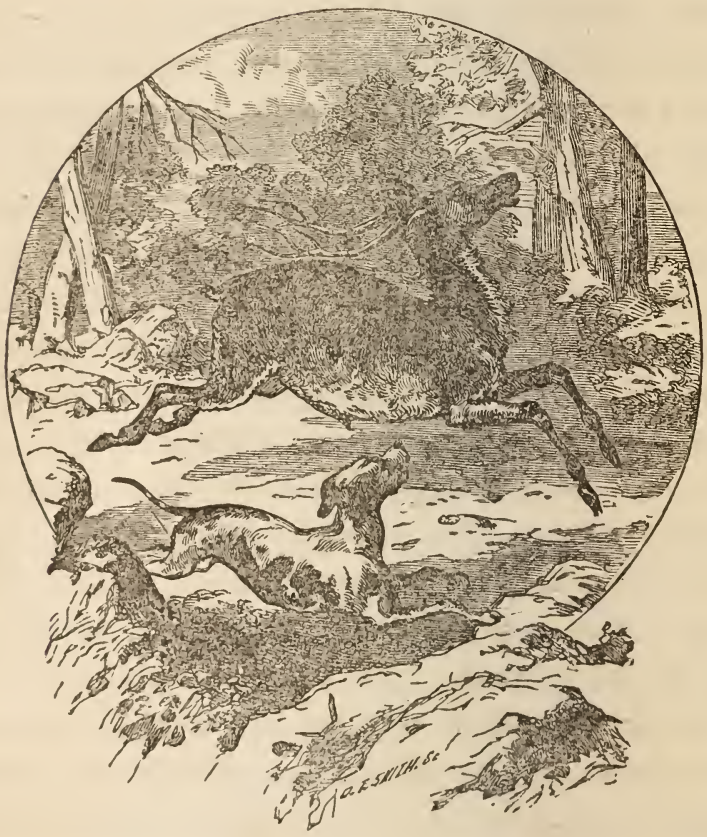

DOG HUNTING A STAG.

He was more fortunate with an arctic or dun-fox, which he pursued, and which he succeeded in taking alive. He also obtained a large quantity of scurvyas it appears to be, chronological, this ought to be, probably, the thirticth. 
grass, and took it on board. He there had the juice pressed out, and poured into a hogshead of beer, and ordered that every one of the crew who desired it might have a pint to drink every morning; but none of them would touch it till it was entirely spoilcd and they were all greatly diseased with the scurry, for which it was believed to be a preventive. This island was named Dun Fox island.

On the 31st he reached a cluster of islands which he called Briggs's Mathematics. On the 9th of August he entered the river Nelson, at the mouth of which he saw several white whales. Here he set up a pinnace, and upon looking around he found the remains of some winter dwellings, which had been erected by Captain Button, who visited this place in 1612. On the 15th the weather was very hot. Passing up the river, the crew on the 17th went a-berrying, and were successful in finding blackberries, strawberries, gooseberries and vetches. They also saw the foot-prints of a stag, and near by the wooden framework of a tent, that had the appearance of having been recently erected. As they looked around they saw a fireplace, the bones of birds and the hair of deer, with other indications that the place had been occupied by men not a great while before; but who they were, how many they were, for what purpose they had been there, or where they had gone, it was impossible for them to tell. Various 
opinions were given by the men, but nothing could be confirmed with certainty. They found a cross overturned, which had been erected by Captain Button as evidence of his having visited the place and taken possession of it in the name of his monarch. This was to the adventurers an interesting object. Fox engraved an inscription upon a leaden plate, nailed this upon the cross, and then re-erected it for the benefit of any other voyagers who might in future risit this spot. He also named the place New Wales.

It being now important that the main-yard which had been lost should be replaced, the carpenter was sent on shore to cut down five of the best trees, which had been marked by the captain as suitable for the purpose. The carpenter found them to be of tolerable size, rourd, but very short, as all the trees in that yegion seem to be dwarfed by the cold. By fastening the timber of sereral of them together, it appeared probable that he might be able to furnish a new main-yard. But, alas, he was doomed to experience disappointment. Of the five trees which had been designated by the captain, not one was suitable for the purpose, as they were all decayed within. Fox now coasted toward the east, and on the 29th of August he fell in with another English ressel. It was to him and his men a source of great delight to know that they were not alone in those northern, inhospitable regions. 
When the men in the two ressels discorered each other, they were mutually anxious to visit each other, and exchange an account of their adventures and discoveries. The new vessel proved to be the "Maria," of seventy tons burden, commanded by Captain Thomas James, which had left Bristol in England two days before Captain Fox left Deptford, and for the same purpose-of discovering, if possible, a north-west passage to India. They were both aware of each other's design before they left home, and it was the intention of their owners that the two vessels should have sailed together on the expedition, and yet this was the first time they had met. After having an opportunity of conversation a short time, they parted. On the $2 d$ of September, Fox came to Cape Henrietta Maria, where the direction of the coast changed from east to south. This cape is the north-western corner of James's Bay. Having satisfied himself that there was no westerly passage into the Pacific Ocean along the coast which he had thus far examined, Fox desired to make another attempt beyond Nottingham Island, where, before, he could not penetrate, on account of the ice. On the 6th, the captain and the boatswain were both unwell. On the 7 th, they had a narrow escape from being stranded, and perhaps wrecked, on Carey's Swan's Nest, the southern point of the island of Southampton. On 
the 15th the vessel was managed with difficulty, on account of the sails being fiozen stiff. On the 18th he saw an elevated cape, to which he gave the name of King Charles's Promontory, to the northwest of which were three islands, forming a triangle, which he called the Trinity Islands, after the brethren of the Trinity House. He also named various other capes, islands, and inlets, which it is not necessary here to specify, and then set out on his return home. On the 5th of October, the cold being severe, the decks, sides, rigging, and sails of the ressel were completely coated in ice, giving it the appearance of a glass ship. Having reached the Atlantic, the captain perecired that a strong current was sweeping him rapidly to the sonth. He, however, soon got out of it, crossed the Atlantic, sailed through the British Chamnel, and reached the Downs on the 31 st of October. So fortunate had he been, that he had not lost a single man, and with the exception of his main-yard, he had met with no serious accident to his vessel. He had not, however, discovered, the north-west passage !

As the experience of Captain James was of a somewhat different character firm that of Fox, and as the account of his adventures is far more interesting, a detailed narrative of them will be given in the next chapter. 


\section{CHAPTER VII.}

Captain James sails for the North-His trying Position-He is frozen inJames's Ignorance-Dangors to which it leads-Encamping for the WTinter-Peculiar Features of a Northern Winter-The Scurr:-Its Symptoms-Effects of Extreme Cold-Difficulty of Working-Thawing Trees - Medical treatment-A Singular Phenomenon-Finding the RudderDisappointment-Difficulties multiply-Sick recovering-Homeward departure-False Facts.

Captair Thomas James, under the patronage of certuin wealthy merchants of Bristol, sailed in a strong built ship, called "The Maria," of only seventy tons, on the $3 \mathrm{~d}$ of May, 1631. On the tenth of June he was off Cape Desolation. Many islands of ice were floating in various directions, and among them numerous grampuses were sporting. With a sea of an inky appearance beneath them, and a perpetual, thick, and offensive-smelling fog around them, their condition was far from being pleasant. On the 17th they came in sight of Resolution Island, placed at the entrance of Hudson's Straits.

Here he noticed that the motion of his needle was embarrassed, a circumstance which he attributed to the heavy fogs. His ship was now encrusted with 
ice, though this was not the worst of his condition, for mountains and flakes, or large cakes of ice were floating in every direction, which rendered it extremely difficult for him to make headway, and finally stopped him entirely. The ice then closed in around the ressel, and froze together, thus shutting him completely in. He was now drifted hither and thither whithersoever the ice floated. His condition was extremely perilous. The captain seems to have been either a self-conceited, or else an ignorant man; or perhaps both. Two facts which are related of him seem almost incredible. The first is, that he was entirely unacquainted with the royages which others had made before him to the north, and therefore knew not the method which they adopted to relieve themselves from difficulties similar to those in which he was now placed. Far different was it with Captain Fox; he availed himself of every opportunity to gain knowledge respecting the dangers and the different modes of escape which. were adopted in these northern seas. Before he left England, he knew probably all that could be learned concerning the navigation of those waters, without a personal experience of them. In that respect, therefore, he was well fitted for their exploration. The other peculiarity in the case of Captain James was, that he had designedly refused engaging any men as sailors who had, previously to this, made 
royages to the north-west or to the frozen regions of Spitzbergen. Being inexperienced himself, he had refused to engage others who had had experience. The consequence of this folly was, that when he was locked up among the immense masses of floating ice, he knew not what measures had been adopted by his predecessors in like circumstances, and there was no one on board who, from their own experience, could inform him. He was obliged, therefore, to fall back upon his own inventive genius to extricate himself from these, to him, untried perils. His want of experience, however, subjected him to indescribable anxiety and sufferings, and brought him to the very verge of destruction, with his ressel and crew. Through the favor of a kind Providence he succeeded, after an incredible amount of labor, in breaking his little vessel out, and working her through the floating mountains and sharp cakes of ice into Hudson's Bay. He kept on his westward course, directly across the Bay, until he reached the shore, where his peril was inrreased by the vessel repeatedly striking the rocky liottom. Between Port Nelson and Cape Henrietta Maria, he fell in with Captain Fox.

As it was now too late in the season for discoveries, he occupied himself in searching for a good place to pass the winter. Penetrating to the extremity of James's Bay, which is the southern pro- 
longation of Hudson's Bay, he found a place that seemed adapted to his purpose. "After encountering many storms and thousands of perils, among the ice, and the many rocks which are found in that part of the sea, and his ship haring two or three times struck on the shoals, he ran her, himself, aground on the island which he afterward called Charleton Island. With great difficulty and danger they carried their provisions, cables, sails, rigging, clothes, utensils, and a thousand other necessaries on shore. They made themselves some miserable huts of pieces of wood, which they placed in an inclining posture round a tree, and covered them with boughs of trees, and with their sails, which were soon covered over with a good thick bed of snow. Besides this hut, they built another, and a storehouse. The hands, feet, ears, or noses of every one of them were frost-bitten. Their clothes that had lain under water in the ship, they were obliged to dig out of the ice, and after thawing them by the fire, to dry them again. As they gare their ship entirely up for lost, they set about building a small pinnace, with which they hoped, after having once got orer the winter, to save themselves from this dreary place of exile. The cold was most terrible here, in north latitude fiftytwo degrees and three minutes. Wine, sack, oil, heer, vinergar, and even brandy froze to solid ice, 
so that they were obliged to cut the first of these liquors with hatchets and axes. A well which they had dug froze also; but a spring at two or three hundred steps from their dwelling did not

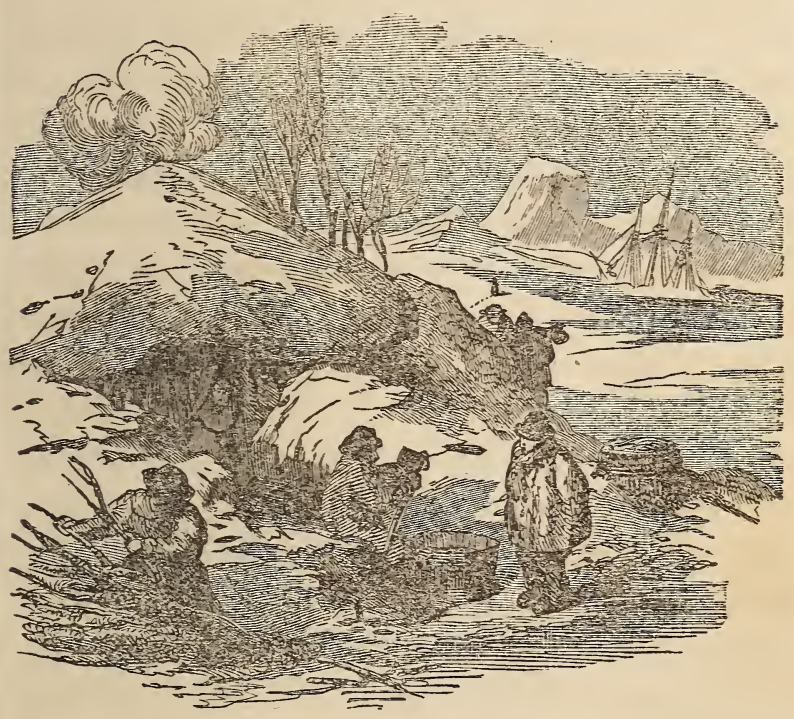

ENCAMIPING FOR THE WINTER.

freeze below the surface, though at the surface it was corered with ice and snow. The sun and the moon appeared on the horizon twice as long as they did broad, on account of the great quantity of vapors with which the atmosphere was filled. The island was quite covered with forests, but contained 
but fer reindeer and arctic foxes. On the $3 i$ si of January, the atmosphere was so clear that Captain James could rery plainly perceire more stars by two thirds than he had ever seen before in his life. The sea was frozen every night some two or three inches thick; but the rising and falling of the tides the next day broke this ice and crowded the cakes over each other, in which condition they wonld frecze together and then become foundations for other cakes to be heaped upon them and frozen fast, and in a few hours become five, six or ten feet thick. These cakes, or embryo mountains, would then be torn from the shore and float about, corering the waters of the bay, and daily increasing its coldness, though when the men waded in the water, notwithstanding it froze upon them, it did not produce so severe a sensation of coldness as in the month of June. This was, probably, owing to the fact that in the month of June the atmosphere being much warmer than in the winter months, there was a greater contrast then between the temperature of the air and of the water, which would imprart a greater sensation of coldness to those who had oceasion to wade. In February, the men were afflicted with that horrible disease, the scurvy. They bled at the mouth; their gums were swollen, and sometimes black and putrid, and all their teeth were loose. Their mouths were so 
sore that they could no longer eat their usual food. Some complained of shooting pains in the head, others in the breast, others felt a weakness in their reins, others had pains in their thighs and knees, and others, again, had swollen legs. Two thirds of the crew were under the hands of the surgeon, and, nevertheless, were obliged to work hard, though they had no shoes to their feet, but instead of shoes, fastened clouts about them. In the open air the cold was quite insupportable, no clothes being proof against it, nor any motion sufficient to keep their natural warmth. It froze the hair on their eyelids, so that they could not see, and it was with difficulty that they conld fetch their breath.

In the woods the cold was somewhat less severe; jet here they were afflicted with chilblains on their faces, hands and feet. The least-degree of cold was within doors. On the outside, the house was covered with snow two thirds of its height, and withinside every thing was frozen and hung full of icicles. Their bedding was quite stiff, and corered with hoar-frost, thongh their befls were almost close to the fire in their small dwelling. The water in which the cook soaked the salt meat, froze within doors, though it stood but three feet from the fire. But during the night, when the fire was not so well kept up, while the cook slept only for four hours, all was 
fiozen in the tub into one lump. When afterward the cook soaked the meat in a copper kettle close to the fire, to prevent it from freezing, the side near the fire was found to be quite warm, while the opposite side was frozen an inch thick. All their axes and hatchets had been spoiled, and rendered unfit for use by cutting the frozen wood, so that Captain James found it necessary to lock up the carpenter's axe, in order to prevent it from being spoiled also. The green wood that they burned in their dwelling, almost suffocated them with smoke; that which was dry, on the contrary, was full of turpentine, and produced so much soot, that they themselves with all their beds, elothes, and utensils, were covered with it; and in short they looked like chimney-sweepers. The timber, knees, beams, and bent pieces, wanted for the construction of their pinnace, caused the greatest difficulty, as the trees, before they could fell them, were obliged to be thawed by the fire. After this, the pieces were first hewn out in the rough, then dried again, and at length worked into the last form that was to be given them, and fitter into each other; for which purpose they were obliged constantly to keep up a large fire near the stock, as otherwise it would have been impossible for them to have worked there. Many of them were disabled by the scurvy, or had frozen limbs, boils and sores; others were every 
morning so contracted in their joints by the rheumatism that it was necessary to restore the suppleness and pliancy of their limbs by fomenting them every morning with warm water and a decoction of the fir-tree, before they were able to go a step forward, or to make use of their hands. In the month of March the cold was as serere as in the midst of winter. In April the snow fell in greater quantities than it had done during the whole winter, but the flakes were large and rather moist, while in the winter the snow was dry, like dust; even on the 5 th of April, the spring which we mentioned they had found, was frozen. An island that was situated at the distance of four leagues from them they could never see from a small hill in fine weather, and when the air was clear; but, on the contrary, when the air was thick and full of rapor, the island was visible, eren from plain, level ground.*

The ressel which had been run aground the year before, and which had suffered from the ice and weather, they began to clear away, in order to see if there was the least possibility of its being able to carry them home. The whole company worked with all the energy and strength they possessed. They were particularly desirous to find the rudder which had been beaten off by the ice many months before, and after a great amount of serere toil, they

* Forster. 
discovered this important article, and hoisted it on deck; they also got the anchor on board, and, to their great joy, found the vessel much less injured than they had feared. At the time they run her upon the shore they bored holes in her bottom for the purpose of letting in water, which, by freezing, might increase her weight, keep her steady, and thus render her less liable of being lifted and dashed to pieces upon the rocks. These holes they now found, and at low water, succeeded in closing them. They also found both of the jumps choked up with ice. These they thawed out, and then used them in pumping the water out of the vessel. On the last day of April, they were favored with a sign of the approach of spring, in the falling of rain.

The men hailed this favorable indication with great joy, as it furnished them with grounds of hope of a speedy departure for their own land. They had become heartily wearied of the barrenness, coldness and suffering of the frozen north, and were filled with gladness when the rain indicated that their release was at hand. Their joy, however, was of short duration, for on the second of May the atmoswhere was filled with snow, and the weather was extremely cold. By this sudden blighting of their hopes, the men were greatly depressed. The disorders of the sick increased to such a degree that they fainted away whenerer they were rised from 
their bed. Large flocks of geese and cranes now visited the island, but they were too discreet to allow the men to come within musket-shot of them. On the 24 th of the month, the party were startled by a loud noise resembling thunder, which they soon discovered was occasioned by the breaking up of the heavy ice in the bay. Though at that time the sun was hot in the day, the water froze at night. On the last day of the month they found a few vetches-a pod-bearing plant-which they gathered and prepared for the sick. During the whole of May the wind blew chiefly from the north, and on the four first days of June, they had storms of snow, sleet and hail. So severe was the cold in that month, that their newly-washed clothes were frozen stiff on the line, and ice was formed in pitchers within the house. On the 9 th the sick had so far recovered as to be able to creep about the house. Some who had been but slightly diseased, had become comparatively strong. The green vetch leaves had produced a favorable effect. They were in the habit of eating them twice a day, dressed with vinegar and oil. They also bruised them and mixed the juice with their drink. Some preferred to eat them raw with their bread. On the 11th they adjusted their rudder in its proper place, and cast out the ballast of the ship. By the 15 th, those who were on the sick list were so far recovered that $9 *$ 
they could walk about. Their teeth were no longer loose, nor their gums sore, so that they could eat their vetches with beef, which we may suppose was none of the most tender. The water of the bay continued full of ice. On the 16 th not only were there thunder and lightning, but the weather was so hot that the men went in bathing to cool and cleanse themselres. The warm weather brought out an immense number of musquitoes, which prored to be great plagues. They were accompanied with ants and frogs. But birds, bears and foxes had totally disappeared. Finally, on the 20th, they got the ship afloat in deep water, although plenty of ice surrounded it. The sailors now engaged with alacrity in rigging the ship, and getting on board their provisions, clothes and other necessaries. All things being ready, on the second day of July they set out on their return, parting with their ice corered dwelling and store, but without the least emotion of regret. At Cape Hemrietta Maria they gave variety to their employment by landing and engaging in the chase after some stags, which they saw there. But neither dogs or men could orertake them. They were probably too much weakened by their privations during the winter, to run with any great speed. With the fowl they were more fortunate, having obtained half a dozen geese. Although it was now mid-summer, yet so great wis 
the quantity of ice in the bay as to subject them to very great labor in working through it. Howerer, by perserering through many discouragements, they finally succeeded in reaching Carey's Swan's Nest, and then Nottingham Island. Their stock of provisions being limited, and their old crazy ressel leaky, the captain as well as the men were anxious to hurry homeward. They did not therefore stay to make any further discoveries. James was the less inclined to linger any longer, because he was of opinion that no outlet to the north-west could be found there. He based this conclusion upon the following reasons : "First, because the tide in every part of this sea comes from the east through Hudson's Straits, and the further it goes the later it arrives at every place. within the strait and bay. Secondly, because these seas contain no small fish, such as cod, stockfish, etc., and few large ones, which likewise are seldom seen. Neither are there any whale-bones nor any seahorses, or other large fish found on the shore; nor is there any drift-wood here. Thirdly, because the ice in $65^{\circ} 30^{\prime}$ north latitude, lies in large fields, or flakes on the sea, because it is generated in the flat bays, but if there was a great ocean further on, nothing but large mountains of ice would be found, such as are at the entrance of Hudson's Straits, and further on to the eastward. Fourthly, and lastly, because the ice drires eastward through 
the straits into the great ocean by reason that it comes from the north and has no other way to go out by." James therefore steered at once for England, and arrived at Bristol on the $22 \mathrm{~d}$ of October 1632.

The argument of Gaptain James against an outlet from Hudson's Bay to the north or the northwest, are far from being conclusive. Indeed, some of them were based upon false premises. His first reason was true only in its application to certain parts of the bay-particularly the southern portion where he wintered. But at Sir Thomas Roe's Welcome, in the north-western part of the bay, the tide rose higher than it did at the mouth of Hudson's Straits. His second reason was shown false by Captain Cox, who saw many whales and seaunicorns in the bay. His last reason furnishes an argument against his own conclusion, for as there is always large quantities of water coming from the north, which breaks the ice in the bay, and drives it out eastward through Hudson's Straits, this would seem to indicate that there was an influx in some quarter from the north, pouring its waters into the bay and compelling them to find an outlet through Hudson's Straits. 


\section{CHAPTER VIII.}

De Groselie-Information from the Ottawas-Hunters and Trappers-De Vries's Voyage-Smelling the Land-A dreadful Scene-Its Perpetrators unknown-The Particulars-Effects of Confidence-Indian Treachery and Revenge-Peace concluded-Beans wanted-Startling Intelligence -Boat's Crew murdered-A suspicious Circumstance-Chief's VisitGifts given and refused-A Peach-tree found-Interview with the English-Seven Whales taken-Whaling unprofitable.

Captains Fox and James were not the only ones who, about that time, made explorations at the north. A Canadian named De Groselie, a man of an adventurous and persevering spirit, who had traveled extensively through various parts of Canada, had learned from the Ottawa Indians the existence of a great bay to the north. When he returned to Quebec he aroused a number of his countrymen to an attempt to reach this bay by water. They joined together, fitted out a bark, and soon after set sail. After meeting with the usual incidents of a sea-voyage to the north, they entered a river which the Indians called the Tearing Stream, probably because its water was torn and rendered wild and turbulent by rocks and rapids in its course, "and which is situated but one league 
from Port Nelson River, called by the French Riv ière de Bourbon. He fixed his residence on the south side, on an island, three leagues up the river: The Canadians, who were good sportsmen, arrived length, in the midst of winter, at Port Nelson River, and there discovered a settlement of Europeans. He therefore went thither, with his people, in order to attack then, but found only a miserable hut, covered with turf, and containing six half-starred people." It appeared that these miserable men, whom De Groselie was about to attack, had belonged to a ship from Boston in New England, and had been put on shore to discover a convenient place where the whole crew might safely pass the winter. After they had landed, the ship to which they belonged was driven by the wind and ice, out to sea, and they had heard nothing from her since. Left, as they must have been, withont food, fuel, or extra clothing, their condition must have been severely painful. It is left for the imagination to conceive what must have been their suspense, their hopes and fears, as day after day passed away without bringing any tidings of the missing ressel, and what must have been their despair when they abandoned the expectation of ever seeing her again.

The same winter De Grosclie received information that about seven leagues from his residence, a 
company of Englishmen had formed a settlement on the banks of Port Nelson River. He resolved to make war upon them, and either drive them off or take them prisoners. But having learned that the place of their residence was fortified, he concluded to delay his attack upon them until some English holiday arrived, when they would probably be indulging in merry-making and carousal, and so be off their guard. Accordingly, on Twelfth Day, he marched upon them, with fourteen Frenchmen, and, to his great joy, he found the English so intoxicated that, though they numbered eighty, they were unable to offer the least defense; so he made them all prisoners, and thus became nuster of all that country. Not long after this, in 1669, the Hudson's Bay Company was formed in England, to whom was given the monopoly of mining, hunting, and trading, within a very large extent of country in the vicinity of Hudson's Bay. They formed friendly relations with the Indians, engaged in trading with them, and from them obtained, in the course of a few years, large quantities of beaver, deer, and elk skins, for which they paid in the cheap trifles and productions of European manufactures. They also engaged hunters and trappers from civilized nations, who were allowed to hunt, upon certain conditions, on the lands, and along the streams, belonging to the company; one of which was that 
- the skins which they obtained should be disposed of to the Company. It proved to be an extremely profitable corporation.

While the adventures which we have narrated were transpiring in the cold and dreary north, and Captains Fox and James were endeavoring to find some channel through which they might thread their way from the Atlantic to the Pacific Ocean, and thus shorten the distance between Europe and the remote spice regions of Cathay, another_enterprising navigator was pushing his investigations further south, and endeavoring to find a convenient place to establish a permanent settlement on land, as yet unoccupied by any European nation. This was David Pieterszen de Vries.*

De Vries was a bold, skillful, and experienced

* Mr. Bancroft, in a note to his History of the United States, vol. ii., p. 282, says: "The only copy which I have seen of the voyage of De Vries, in the original language, is to be found in vol. i. of the Du Simitière MSS., in the Philadelphia library. Dr. Julius, of Hamburg, has discovered in the royal library at Dresden, Saxony, a printed copy. The book escaped the research of Ebeling, and was not discovered by Lambrechsten. For the use of an English MS. translation, I am indebted to the great liberality of J. W. Mouiton." This translation was mado from the original Dutch, by Dr. G. Troost of Philadelphia. It bas since been published in the "Collection of the Now York Historical Society. New Series, vol. i.," and from it we havo drawn up our narrative. As the information which it contains will be now to many of our readers, we shall give it with considerablo minuteness. 
navigator. He had formed an acquaintance with the climate, the commerce, and the people of the East Indies, by voyages that he had made there. After returning from there, he met with Samuel. Godyn, a distinguished merchant of Amsterdam, who offered him an opportunity of visiting North America, under what was then considered favorable auspices. He accepted the offer, and entered into an agreement or "patronship" with Godyn, Killian Van Rensselaer, Samuel Bloemart, and Jan de Laet, who were all, by the terms of their agreement, "placed on an equal footing." Their object was twofold: to establish colonies in what was then called " $\mathrm{F}$ ew Netherlands," extending from the fortieth to the forty-fifth degree of north latitude, and to engage in the whale fishery in the vicinity of the Delaware River, where whales were supposed to be abundant.

Accordingly, on December 12th, 1630, De Vries sailed from Texel for the Delaware, which, at that time was called the South River, to distinguish it from the Hudson, which was called the North River. He was accompanied by about thirty emigrants, who were to constitute the new colony. They successfully reached Delaware Bay, sailed up the river, and just within Cape Henlopen, where Lewistown now stands, they established the new set. tlement, that region of country being then called 
Swan's Dale. A block house was built, palisades were erected, and agriculture commenced. De Vries left them with the expectation that they would become a permanent plantation, and returned home. The next year he came back, not to inquire after their welfare-for intelligence had reached him that a dreadful catastrophe had occurred, by which the whole colony had been swept away-but to ascertain particulars, traffic with the natives, and visit other colonies.

December 1st, 1632, he found himself near the coast of America, in fifty-seven fathoms of water. They could plainly smell the fragrant odor of the underbrush, as it was borne to them from the fires which the Indians kindled at that season of the year, in order to render the woods and country more favorable for hunting. "We smell the land, therefore, before it can be seen." When between the latitudes of thirty-four and forty, with the water at thirteen fathoms, they had a view of the coast. On the 5th, they entered Delaware Bay; they were accompanied by a whale playing around them. "We promised ourselves," says De Vries, "great things; plenty of whales, and good land for culti. vation."

The next day they took the boat, and being well armed, in order to protect themselves against the Indians, if they should be attacked, they passed up 
the river, and examined the place where the little colony had been left the year before. It presented a melancholy scene. The blockhouse was destroyed, the parapets burned, and the ground scattered over with the skulls and bones of their murdered countrymen. That this dreadful tragedy had been performed by the savages, there was but little if any doubt; but as to the cause which led to it, or the circumstances attending it, they were left in impenetrable darkness. It was new the policy of De Vries to discover, if he could, all the facts in the case; for this purpose he was anxious to obtain an interview with some of the natives. After gazing upon these affecting memorials as long as they desired, the company returned to the vessel, pondering with sad emotions upon the untimely end of these adventurous pioneers. After they reached the ship, De Vries ordered a gun to be fired, to see if any of the Indians would show themselves. The next day two or three were seen near the ruins of the blockhouse. They refused to approach the ship, but signified that they wanted to receive a visit. The next day being December 8th, "We went in the yacht," says De Vries, "up the creek to the house. The Indians came on shore, but would not at first come on board. At last one came. I gave him a dress of cloth, and we told him we wished to make peace with them. There now came more Indians, who expected also 
a dress, but we gare them only some trinkets, and told them that we had presented the other with a dress, because he had shown more confidence in us, as being the first that rentured to enter the boat. We told them to come the next day with their chief, whom they called Sakimas, with whom we would make a satisfactory peace, which they called Rancontynmarenit. One of the Indians remained with us during the night in the yacht." De Vries took advantage of the prolonged, confiding risit of this one, to inquire concerning the particulars of the fate of the destroyed colony, the account of which, as it is the only early statement known to exist in our language, we will give in his own words: "We asked him the reason why they had killed our people. He showed us a place where our people had emptied a pillow, to which was attached a piece of tin upon which was figured the emblem of Holland. One of their chiefs wanted to take this piece of tin to make of it tobacen-pipes, not knowing that it was improper. Those who had the command at the house showed much dissatisfaction, so that the Indians did not know how to make amends. They went away and killed the chicf who had taken the tin, and brought a token of it to those who had the command at the house, who told them they had done wrong, that they onght to have come with him to the honse, and they would have only told 
him, not to do so again. They then went away; but the friends of the murdered chief (the people haring much the character of the Italians, who are greatly addicted to rengeance) had resolved to be revenged. They attacked our people when they were working in the field, learing but a single sick man in the house, and a large bull-dog, which was chained out of doors. The man who had command of the house stood near the door. Three of the boldest Indians, who were to perpetrate the deed, came and offered him a parcel of beavers to barter, and contrived to enter the honse. He went in with them to transact the business. That being done, he went to a garret where the stores were. Coming down, one of the Indians cleaved his head with an axe, so that he dropped dead on the floor. They then murdered the sick man and then went to the dog, which they feared most, and shot at least twenty-five arrows at him before he was killed. They then went in a treacherous manner to the people in the field, approaching them under the appearance of friendship, and murdered one after the other." Thus fatally terminated the existence of the little colony on the Delaware. The trouble was occasioned by the indiscretion of the Indians in murdering the chief who had taken the piece of tin, which per. haps had been hung up as evidence that the Dutch had taken possession of the country. This kindled 
the fire of revenge in the bosom of the murdered chief's friends, which could not be extinguished except with the blood of the whites.

On the 9th the chief of the place visited De Tries, accompanied by many of his tribe. They arranged themselves in a circle, entered upon negotiations, and concluded a peace. De Vries thought it best to ask no satisfaction for the slaughter of the colonists, nor even to make the least allusion to it; for knowing the migratory habits of the natives, he was aware that if they refused to render satisfaction, it would not be in his power to inflict upon them what might be regarded as deserved punishment, and therefore it would be more prudent not to refer to the subject at all. He therefore ignored the whole matter.

He presented them some blankets, bullets, axes, and toys, for which they promised to reciprocate by giving in return some game, which they had recently taken.

As the Dutch expected great success in catching whales, they now made preparation for lodging on land, and boiling the oil.

On the first day of the new year he ascended the I) olaware River in the yacht, to obtain, if possible, some beans from the Indians. His hopes of successful fishery were kept up by seeing a whale in the Bay. Four days afterward he visited a small 
fort which had been erected by the Dutch in 1623, a few miles below the present site of Philadelphia, on the east bank of the Delaware, and called " Fort Nassau." It was now unoccupied, the attempt at colonizing here being abandoned. He here met with a few Indians, who had some furs which they purposed to exchange for European commodities; but as De Vries's stock of goods was limited, he was unwilling to part with any thing, except for beans, especially as he had made them presents at Swan's Dale when they negotiated peace. Being either unable or unwilling to supply them with beans, the Indians advised them to go to the Timmerkill, now called Cooper's Creek. The prudent counsels which were at the same time given them by an Indian woman, were probably the means of preserving their excursion from reaching a tragic and perhaps fatal termination. She warned them not to go up to Timmerkill, because they would be attacked. Having received this important information, they were anxious for more, and therefore gave her a dress of cloth, to induce her to tell all she knew. She then told them that a boat's crew, which had ascended the Count Ernest Rirer, had all been murdered. Although this intelligence did not induce De Tries to relinquish the attempt of reaching the Timmerkill, it made him more cautious and rigilant, and induced him to adopt a different 
tone in his dealings with the natives there from what he otherwise would have indulged.

He reached the Timmerkill next day, fully prepared for any emergency. It was not long before a large party of Roodehoek or Mantes Indians approached the boat, bringing with them beaver skins to barter. Over forty of them entered the yacht, the crew of which numbered only seven. Some of these natives began to play on a rude musical instrument, like a flute, so as to prevent awakening suspicion. Others loitered carelessly around, and others made proposals of trade. After a while De Vries thought it best for them to withdraw, and accordingly ordered them all off, at the same time threatening, if they did not comply, that he would fire on them. This induced one of the chiefs to offer an armful of beaver skins to them. But the Dutch refused them, and ordered them peremptorily ashore, stating that Mantes-the Indian name for the Evil One-had revealed to them that they intended some wickedness against them. The Indians then thought it best to retire, and accordingly withdrew to the shore. So that, if any villainous plot had been arranged by them, it was entirely defeated through the vigilance and decision of De Vries. A circumstance which increased the suspicion of the captain, and gare weight to the testimony of the woman, concerning the bad char- 
acter of these fellows was, that some of them wore English jackets. As these were never made an article of barter with the natives, it is difficult to conceive how these Indians came, honestly, in the possession of them. If they had ever murdered a boat's crew as the woman had said, they might hare stolen them then.

The next morning the captain again presented himself in the stream before the fort, which was soon crowded with Indians, who kept increasing more and more. A canoe put off the shore to the yacht, carrying nine chiefs from different places, among whom was one of those who, the day before, had worn an English jacket, which, however, he had laid aside now, perhaps in order to avoid exciting suspicion, or being questioned concerning it. "They sat down in a circle, and called for us, saying that they saw that we were in fear of them; that they came on purpose to conclude a permanent peace with us, presented us with ten bearer-skins, the gift of every one being accompanied with some ceremonies, saying at the same time in whose name it was given, as a token of eternal peace; and that we must now banish all suspicion, as they had re. jected all evil thoughts. I then offered them, by the translator, some presents for each, consisting of an ax, adze, and a pair of small knives; but these they refused, saying that they did not give their 
presents to receive athers in the place of them, but in order to make peace. We told them that we would give them something for their wives; but they told us we must give it them on shore. On the 9th and 10th got some Indian corn and furs on barter of them."

Ten days after this he ascended a fine stream; found the country beautifully diversified with romantic scenery, and, as many luxuriant vines with their rich clusters ornamented the sides of the narrow river through which he was sailing, he gave it the appropriate name of "Vine Creek."

It was the desire of De Vries to explore the Delaware much further than he had done, but as he could not obtain sufficient provision from the Indians to meet his wants, he concluded to make a voyage to the English setlement in Virginia, in. hopes of finding a supply there. On his way thither he noticed that the land was in a more advanced and settled state. He saw, for the first time, a peach-tree (one would suppose from this, that the peach-tree was indigenous.) He had an interview with the Governor of Virginin, who, when he learned that his Dutch visitor had come from the South River, took occasion to inform him that this river was the property of the English; that some time before, Lord Delaware had entered and taken possession of it, but as he found it difficult of navi- 
gation in consequence of numerous sand-banks, he did not ascend it. He also told him that he had sent a sloop there, but as it had never returned he thought that it must have been lost at sea with all on board. De Vries replied to his excellency, that he was mistaken; that the South or Delaware River had for many years belonged to the Dutch, who had erected a fort on one of its banks, that it was a noble stream, and easily navigable. He also informed the governor that the Indians on that river had told him that the crew of an English boat had been murdered there, and that their clothing he had seen worn by the natives.

The interview seems, on the whole, to have been a pleasant one, for, at its conclusion, the governor gave De Vries six goats to be introduced into his new colony. After purchasing a supply of provisions, the captain returned to the Delaware, and found that those who had been left there to prosecute the whale fishery had taken seven whales, which had furnished thirty-two cartels of oil. This, however, was such a poor return for the amount of money which had been invested in the business, as to shc $N$ that the enterprise was unprofitable. After this, De Vries made several voyages to the Dutch settlements in New York. 


\section{CHAPTER IX.}

Gustarus Adolphus-His plans of Emigration-A War defeats themDeception of the Swedish Governor-Fort Casimer taken by TreacheryGoverıor Stuyvesant attacks Delaware-Rumors of a Silver MountainAn Indian brings Ore-He is Assassinated-The English conquer the Dutch-Cbildren stolen by the Savages-Their Redemption-price in Tobacco-Commercial Regulations-Famous Navigation Act.

Ix 1620, Gustavus Adolphus, King of Sweden, who had received very glowing descriptions of the salubrity of the climate, the fertility of the soil, and the romantic character of the scenery of New Netherlands, published an address to his subjects, earnestly urging them to associate together for the purpose of forming a settlement in this charming country of the New World. His address awakened great attention among the Swedes; led to much conversation, in which the project was probably fully discussed on both sides, and resulted in the adoption of measures for raising a fund by voluntary subscription for the olject. Persons of all classes became interested in the enterprise. An admiral, vice-admiral, merchants, assistants, commissaries, and a military force, were duly appointed. 
It seemed as if every arrangement was made for the establishment of a permanent and flourishing colony; but the difficulties occasioned by the outbreaking of a German war suspended the operations.

In the course of a few years, several different settlements were formed on the Delaware by the Dutch and the Swedes, who held the country in common, until the erection of a fort by the Dutch at Sandhocken, now called Nerwcastle, excited the anger of the Swedes, and led to hostilities. The Swedish governor, Risingh, demanded that this fort, which had been named Fort Casimer, should be delivered to him; the Dutch, of course, refused. Risingh then resolved to obtain possession of it, either by force or fraud. For this purpose he approached it under the garb of friendship. Having arrived in a boat opposite to the fort, he honored it by firing two military salutes. By this deception the Dutch were effectually thrown off their guard. Risingh then landed thirty men, whom the Dutch, in the simplicity of their hearts, received within their gates as friends. When once in, the Swedes threw off their mask, revealed their true object, overpowered the unsuspecting Dutch, seized the stores, ammunition, and merchandise of the place, and even compelled some of the conquered Dutch to disown their natire country, and swear allegiance 
to the Swedish Queen. Fort Casimer was now in the possession of the Swedes.

When the news of this outrage reached the redoubted Stuyvesant, who was then Governor of New York, he resolved to inflict instant and fearful vengeance. As there were several different Swedish settlements on the Delaware, it was the intention of Stuyvesant, under direction of the home government, to sweep them all away, and take possession of the whole of that country. After considerable time was spent in collecting his forces, and completing his arrangements, the Dutch governor presented himself in the Delaware, with seven vessels, and nearly seven hundred men. The Swedes were alarmed, but could not arrest the progress of this invading fleet. Stuyvesant first attacked and took possession of Elsinborg. He then adranced upon the fort of the Holy Trinity. After landing his men, and protecting them behind intrenchments, he demanded the surrender of tho place, threatening, in case of refusal, the severest treatment known in war. The fort capitulated, and soon the flag of the Dutch was seen waving from its walls, where a few minutes before the colors of the Swedes were gayly flaunting in the brecze. He next appeared before Fort Casimer, then under the command of Sven Scutz, and summoned him to yield. Scutz asked permission to consult with the 
governor before replying. Stuyvesant was in no mood to comply with this request, and therefore denied him the privilege of the desired conference. Believing that a conflict would result only in a useless shedding of blood, Scutz made an honorable surrender. He was permitted to march out in military array, to retain the arms of his troops, and the battery of the fort. Thus Fort Casimer was retaken, and probably some of the old Dutch garrison replaced there. Stuyvesant then passed on to another fortress stronger that of Casimer, and called Christina. It was under the command of Risingh himself. $\mathrm{He}$, being equally unable with the the others, to resist the invincible Dutchman, soon followed their example and submitted. All that now remained to the Swedes was New Gottenburg, with its fort and church, but when this was subdued, which occurred soon after, the provincial power of New Sweden was effectually destroyed, and the Dutch obtained possession of the Delaware.

It was said the Swedes discovered some valuable gold and silver mines in Delaware. The account given by Lindstrom in his manuscript journal, as quoted by Gordon, is as follows: "The shore before the mountain is covered with pyrites. When the roundest are broken, kernels are found as large as small peas, containing virgin silver. I have broken 
more than a hundred. A sarage Unapois beholding a gold ring of the wife of Gorernor Printz, demandel why she carried such a tritle. The Governor replied, 'If you will procure me such trifles, I will reward you with other things suitable for you.' 'I know,' said the Indian, 'a mountain filled with such metal.' 'Behold,' rejoined the Governor, 'what I will give you for a specimen,' presenting to him at the same time a fathom of red and a fathom of blue frieze, some white-lead, looking-glasses, bodkins and needles, declaring that he would cause him to be accompanied by two of his soldiers. But the Indian refusing this escort, said that he would first go for a specimen, and if it gare satisfaction he might then be sent back with some of the gorernor's people. He promised to give a specimen, kept the presents, and went away. After some days he returned with a lump of ore as large as his doubled fist, of which the Governor made pronf, found it of good quality, and extracted from it a considerable quantity of gold, which he manufactured into rings and bracelets. He promised the Indian further presents if he would discover the situation of this mountain. The Indian consented, but demanded a delay of a few days, when he could spare more time. Content with this Printz gave him more presents. The savage, having returned to his nation, boasted of his gifts, and declared the reason 
of their presentation. But he was assassinated by the sachem and his companions, lest he should betray the situation of the gold mine, they fearing its ruin if it were discovered by us. It is still unknown." It is not unlikely that what was supposed to be gold was pyrites, which is composed of sulphur, iron, copper and cobalt, or nickel, and which presents a yellowish golden lustre. It has often been mistaken for the precious metal, and has awakened high hopes which were destined in a short time to be utterly blasted.

In the year 1664 the English, who for a long time had been jealous of the encroachments of the Dutch, came upon them with a considerable army, and subjugated them to British rule. This led to an European war between these two nations, and at its close the English held all the places which they had taken, previous to the outbreak of the European conflict.

To return again to Maryland, we find that the colonists there were frequently harassed by the In. dians. Laws were passed against them; companies were recruited to go upon their settlements and punish them for their cruelties. They stole whatever property they could lay their hands on; they murdered the men whom they found straying from the towns, and kidnapped children for the purpose of receiving for them a high ransom.

On one occasion two children of $\mathrm{Mr}$. Thomas 
Allen were seized by these savages and carried away. So soon as it was known, the whole colony were greatly excited, and measures were speedily adopted to ascertain where they were taken and by what means they could be recovered. Inquiries were sent to the Indians, and ere long it was discovered that they had not been put to death, but were held as captives. It was then asked whether they could be ransomed; the reply of the savages was, that they would be restored upon the payment of fifteen hundred jounds of tobacco. A circumstance which rendered this case more affecting was, that these unfortunate children were fatherless. Mr. Allen had died some time before, and the little property which he left was not sufficient to redeem them from bondage. Their case was therefore presented to the provincial court, which, after hearing the facts, referred it to the Assembly. The disposition, which this latter body made of these children reflects no honor upon their generosity. Of the fifteen hundred pounds of tobacco, which was asked as the redemption price, nine hundred was to be fraid for the oldest and six hundred for the youngest. "The order by the Assembly was, that " the said two children should serve any inhabitant of the province till they attain to their several ages of twenty one years, as the provincial court shall think fit; such inhabitant paying the said charge of their redemp- 
tion." According to this order the children were to be bound out, until they were twenty-one years old, to any person in the province who would pay the amount required for their ransom. It was equiv. alent to hiring the children for that amount until they were of age. The reason assigned for this singular order in so peculiar a case was, that "the public charge this year being like to be very great and burdensome."

As the colonies in America increased, they cultivated the land, and extended their trade with the Indians, and in these ways were enabled to send to England a considerable amount of merchandise of the natural productions of the country. This gave employment to vessels and men. But as the Hollanders, or Dutch, would transport freight across the Atlantic at a lower rate than the English, they monopolized nearly all the carrying trade. English merchants themselves employed Dutch vessels. Thus English ships, for want of employment, were going to decay at the wharres, and English sailors were compelled to enter the service of the Dutch.

The English Parliament, in order to arrest a state of things so ruinous to their commerce, passed what has been termed "the famous Narigation Act," the leading feature of which was: "That no merchandise either of Asia, Africa, or America, including also the English plantations there, should be imported into 
England in any but English built ships, and belonging either to English, or English plantation, subjects, navigated also by an English commander, and three fourths of the sailors to be Englishmen." By this act the business of the Dutch, as carriers of freight between the English colonies and the mother-country, was effectually destroyed, and a fresh impetus given to the employment of English vessels and men for that purpose. 


\section{CHAPTER X.}

A remarkable Fact-Political Troubles-Seizure of Arms and Ammunition Resisting Authority-The Governor's Protest-A noble Resolution-A Boat seized-Terrific Threatenings-A Council of War-The Golden Lion-A deceptive Trick-Stone fired upon-A Battle-The VictoryThe Prisoners-The first Account sent Home-Reconciliation between Protestants and Catholics.

The efforts which were made by Lord Baltimore, at different times, to increase the number of his colonies, proved successful, though some of the emigrants occasioned him no small amount of trouble. Indeed, it is a remarkable fact, that though Maryland was originally settled as a Roman Catholic colony, in order to provide, among other objects, a safe retreat from persecution for the Catholics in the mother-country, and though its proprietary and principal officers were, at first, of that religious persuasion, yet in the course of a few years the controlling power passed from them into the hands of the Protestants. Two important events occurred which proved fatal to the political power of the Catholics in Maryland; the first was the great increase of the Puritans there, especially after they had been driven by persecution from 
Virginia, and the other was the seizure by the Puritans of the reins of government in England, under the administration of Oliver Cromwell.

At the time of Cromwell's elevation to the supreme power of England, Mr. Stone was governor of Maryland. In 1654 he was compelled, mainly through the influence of the Puritans, to relinquish his office, which he held under Lord Baltimore, in order that the colony might be governed by commissioners under the Lord Protector of England, as Cromwell was called.

When intelligence of this state of things reached England, Lord Baltimore was, as might be expected, greatly displeased. He wrote to Stone, censuring him for his conduct. He was also informed that Cromwell had not taken from Lord Baltimore either his patent or his lands. It followed from this representation that those who had compelled the governor to relinquish his office had acted without authority. Stone was stimulated to resume his position as governor. He at once began to appoint military officers and organize an armed force for the purpose of strengthening himself in the government.

Among the commissioners who had assisted in the previous overthrow of Stone, were Captain Fuller and Mr. Richard Preston, the latter of whom had possession of the records of the province. 
These records Governor Stone caused to be seized by a company of soldiers whom he sent to the Patuxent river (where Preston lived) for that purpose. This bold and decisive act led to fatal hostilities. When this seizure of the records was made known to the Council of Commissioners, they sent messengers to make peaceful inquiries of Stone as to his authority for his conduct. "But the said Captain Stone, instead of giving a satisfactory answer, imprisoned the messengers, and in much wrath and fury said he would show no power; at last he affirmed that he acted by authority from Lord Baltimore, and that the Lord Protector had confirmed the Lord Baltimore's power. 'If so, sir,' said one of the messengers, 'if it be confirmed, let that appear and it will satisfy.' 'Confirmed!' said Captain Stone, 'I 'll confirm it;' and so sent them home."*

In addition to the records, Mr. Preston's house contained a considerable amount of arms and ammunition. Governor Stone thought that safety required the seizure of all these. He, therefore, sent a company of armed men, twenty in number, to take possession of them. They were under the command of William Eltonhead and Josias Fendal. They cautiously approached Preston's house, and while some, who had been appointed for that pur* Strong's Babylon's Fall, in Bozman. 
pose, surrounded it, other's entered it and commenced a careful search. Preston himself was nowhere to be found. Guns, swords, and ammunition to the value of thirty pounds sterling were discovered and seized. They then entered other houses in the neighborhood, and took possession of all weapons and ammunition that they found there. In addition to the seizure of these warlike stores, they also took prisoners Preston's deputy clerk, John Sutton-who had been appointed "to attend the records for any who should have occasion to use them, either for search or copy,"-and also Peter Johnson, who held the office of lieutenant. These were detained as prisoners some twenty days.

This first movement of Stone having been so successful, he next attempted the reduction of a settlement called Providence, but now known as Ann Arundel. For this object he collected together about two hundred men of St. Mary's county, who volunteered their services, and eleven or twelve small vessels to transport them across the mouth of the river, as they intended to march along the shores of the bay. The little army set out in the begrinning of April, 165t. On their way, and before they had reached Herring Creek, in Ann Arundel county, they were met by a boat filled with messengers from the government at Ann Arundel, and bringing a letter to Governor Stone, 
protesting against his proceedings, and asking by what authority he acted, and whether he had resolved to aroid all negotiation upon the subject, at the same time declaring "that by the help of God they were resolved to commit themselves into the hand of God and die like men, rather than live like slaves." Instead of returning any answer to this message, Stone seized the boat and made the messengers prisoners. They guarded these, however, so negligently that three of them managed to escape, and carry back to the government at Ann Arundel an account of their treatment, and of the approach of Stone with a hostile force.

When the gorernor and his company of volunteers arrived at Herring Creek, they found there a gentleman who had been appointed one of the comunissioners to manage the affairs of government, after Stone had been deposed. Him they seized and held as a prisoner. As Strong relates it, they " apprehended one of the commissioners, and forced another man of quality to fly for his life, having threatened to hang him up at his own door, and not finding the man, affrighted his wife, and plundered the house of ammunition and provision, threatening still what they would do to the people at Providence (Ann Arundel), and that they would force the rebellious, factious Roundheads to submit, and then they would show their power." 
After this, the governor sent Dr. Barber and Mr. Coursey as his messengers to Ann Arundel with a proclamation, in which he professed he did not come to them to inflict upon them injury, but to bring them to submit quietly to his rule. When these messengers arrived at Am Arundel, they were permitted to read the governor's proclamation, but as they had nothing else to offer, they were then permitted to return. 'This, however, they did not do. The next day Stone sent another messenger; neither did he return, because, perhaps, the near approach of the army seemed to render it unnecessary. As no measures were taken by the people of Amn Arundel to give in their adhesion to the government of Stone, the aggressive army continued their approach, until, on the erening of the day that the last messenger arrived, the whole army of the governor, consisting, as we have stated, of about two hundred men, and twelve ressels, presented themselves in the river before the little town, which was filled with excitement at this warlike array. A council of war was immediately called by Captain Fuller, to decide upon the best course of procedure in the trying circumstances in which they were placed.

In the river was a merchant ship, named the Golden Lyon, under the command of Captain Hamans. The conclusion which was reached by 
the council of war was, that Mr. William Durand, the secretary of the government, should go on board the Golden Lyon, and fasten to the mainmast a proclamation, directed to the captain, requiring him, "in the name of the Lord Protector and Commonwealth of England, and for the maintenance of the just liberties, lives and estates of the free subjects thereof, against an unjust power, to be aiding and assisting in this service." Captain Hamans at first declined engaging in the approaching contest, but upon. further reflection, he offered himself, ship and men, for the service, under the direction of Durand. It is supposed that Hamans was actually hired by the government of Ann Arundel to render them assistance, and that this nailing of the proclamation to the mainmast was only a piece of deception to make it appear that he was impressed into their service, the whole trick having been previously agreed upon bv those concerned.

When the invading fleet had arrived within the outer harbor of Providenee, a shot was fired toward them from the Golden Lyon, with a view, it was said, to induce them to send a messenger on board. But Stone, who regarded it as a signal of war, paid no attention to it, but continued to sail on with his fleet, until he entered the mouth of the creek, on the south of the peninsula upon which Annapolis 
now stands. He then, commenced landing his troops, and while engaged in this, the guns of the Golden Lyon were again opened upon him, sending the shot in such dangerous proximity to him that he considered it best to dispatch a messenger to the Golden Lyon, to inquire into the reason of the firing, and to inform the commander of the vessel that Gorernor Stone thought "the captain of the ship had been satisfied," from which it would seem that Hamans and Stone had previously had some communications with each other, with which Hamans had professed to be, or appeared to be, satisfied. Whatever he might have said before, he now replied, in a rough, blustering manner, to the messenger, "Satisfied with what? I never saw any power Captain Stone had to do as he hath done, but the superscription of a letter. I must and will appear for these in a good cause."

Governor Stone, as a precautionary measure, removed his vessels under the cover of the night, further up the ereck. When this was discovered the other managed to place one or more vessels with two cannons at the mouth of the creek, and in this manner shut Stone in by a blockade. Soon after this Stone paraded his men on the shore, and while going through with his military exercises, the captain of the Golden Lyon fired upon and killed one of their number. This compelled the miniature 
army to move further off. During this time Captain Fuller with a hundred and twenty men went further up the creek in boats, then disembarked and marched round to where Stone and his company were prepared to give them a warm reception. Captain Fuller hoping even to the last that Stone and his Marylander's might furnish some satisfactory reason for this invasion, ordered his men, upon pain of death, not to fire a gun, nor make any attack until they had first been fired upon by the invaders. The standard of the commonwealth of England, under which he marched, was planted in a conspicuous place. At this Stone and his party fired five or six guns and killed one man. This was considered by Fuller a sufficient provocation for an immediate onset. "Then the word was given, 'In the name of God fall on; God is our strength!'- that was the word for Providence. The Marylander's word was:- 'Hey for Saint Maries.' The charge was fierce and sharp for the time; but through the glorious presence of the Lord of Hosts, manifested in and toward his poor oppressed people, the enemy could not endure, but gave back; and were so effectually charged home that they were all routed, turned their backs, threw down their arms, and begged mercy. After the first volley of shot, a small company of the enemy, from behind a great tree fallen, galled us and wounded divers of our men, 
but were soon beaten off. Of the whole company of the Marylanders there escaped only four or five, who run away out of the army to carry news to their confederates. Captain Stone, Colonel Price, Captain Gerrard, Captain Lewis, Captain Kendall, Captain Guitter, Major Chandler, and all the rest of the counsellors. officers and soldiers of the Lord Baltimore, among whom, both commanders and soldiers, a great number being Papists, were taken, and so were all their vessels, arms, ammunition, provision; about fifty men slain and wounded. We lost only two on the field; but two died since of their wounds. God did appear wonderful in the field, and in the hearts of the people; all confessing him to be the only worker of this victory and deliverance."

Such is the Puritans' account of this unfortunate catastrophe, and which must be received with all due allowance, as coming from those who were parties in the affair. It certainly seems remarkable that there was so great a disparity between the slain and wounded-there being fifty on one side, and four on the other, if the whole truth were told. But this was probably not the case. The account gives the whole number of the slain and wounded on the side of the Catholics in one sum, from which we can not tell how many were slain, or how many were only wounded; as it respects the Puritans, it states only how many. were slain, but says nothing 
of the number of the merely wounded. This was not ingenious; for the casual reader would receive the impression that there were only four of that party anywise injured, while the careful reader has no means of showing that this impression is not correct.

Another event connected with this painful collision, and not stated in the Puritan account is, that after the Catholics had all yielded, and were taken prisoners, except the few who fled, a court-martial was held by the Puritans who tried the prisoners, sentenced ten of them to death and executed four. The other six who were condemned were saved by the incessant perseverance of certain good women, who continued interceding for them until their deliverance was secured. They were aided by some of the soldiers, who sympathized with them in their benevolent efforts. This execution of four prisoners of war, reflects no honor upon either the justice or the humanity of the conquerors.

This entire defeat of the Catholic party in their efforts to overthrow the Puritan administration of affairs, served to confirm and strengthen the Puri$\tan$ government throughout the whole province.

As Oliver Cromwell at this time was at the head of the affairs of England, and as the Colonies of Maryland were subject to the government of England, each of the contending parties in the late 
conflict were anxious to present their account of these transactions to Oliver as early as possible, and to justify their conduct before him.

Governor Stone and his counsellors were detained as prisoners a considerable length of time at Aun Arundel, and during this period they could not, of course, give any account of their affairs or conduct to the home gorernment. Stone, eren, was not allowed to write to his wife, except his letters were first examined by his conquerors. This gave the Puritans time to forward their account to Cromwell first. It has been alleged that this was their object in keeping the Catholics prisoners so long.

Another measure of the victorious Puritans, which has received the condemnation of historians, was their sequestration of all the property of Governor Stone and those who had acted with him in the recent conflict.

Although the Puritans now had the control of the government of Maryland, they were not destined long to hold it. Intelligence of all that had been done was forwarded to Lord Baltimore and to Oliver Cromwell. Every measure was adopted by both parties to secure a decision in their respective favor from the lord protector at home. Cromwell, however, was not inclined to enter minutely into the matter. He referred it to others fir examination. There was much delay in getting a 
decision. He seemed to treat the Puritans of Maryland with coolness. The report made by those to whom he reforred the subject was favorable to Lord Baltimore. Still, Cromwell did not ratify it. He pleaded a want of time, arising from more pressing and important affairs. The victorious party in Maryland became satisfied that they would not be protected in their administration of the government. The indications were that the authority of Lord Baltimore would, before long, become paramount in Maryland. The Puritans, therefore, thought it would be the wiser course for them to effect a settlement between themselves and the Catholics, upon some basis of compromise that would be acceptable to both parties. Accordingly such a basis was drawn up, both parties agreed to it, and upon its being duly signed and sealed, the Puritans relinquished to the Catholics the government of the province. Thus Lord Baltimore was enabled to resume his authority in Maryland, after being deprived of it about six years. 


\section{CHAPTER XI.}

Peace and Prosperity-A great Country-Its possession desirable-Origin of the French War-Chain of Forts-Preparations for a CampaignFranklin's patriotism-Bradilock's arriva!-George Wasbington becomes his Aid-de-camp-Washington Sick-A Wagon his IIospitalMarch of the Arm $y-A$ beautiful sight $-A n$ invisible, terrible Foe-An Indian Ambush-Surprises the Army-Washington's Perils and Escapes - The Killed and Wounded-Singular Interview between Washington and an Indian-The Indian's Story-His Rerurence for Washington.

For a long series of years the history of Maryland was marked by peace and prosperity. Various misfortunes, which other American colonies experienced, she escaped. New settlements were formed, new towns sprung up, new lands were cultivated, and the number of inhabitants, so essential to the power and prosperity of a community, was greatly increased. In 1756 the population of Maryland was estimated at 154,188 , of whom nearly 108,000 were whites, and over 46,000 were blacks.

In 1754, a war broke out between the English and French, in which the American colonies took an active part, which furnished occasion for the display of great bravery on the part of officers and troops from Maryland. 
To the minds of thoughtful and ambitious men, it was evident that the acquisition of large portions of the American continent was extremely desirable. Here was a country of some thousands of miles in extent; channeled by mighty rivers, that intersected it in every direction; covered extensively by forests, capable of furnishing wood and timber to meet nearly the demands of the world; with inexhaustible stores of mineral wealth; and a climate so varied as to be favorable to the productions of all the zones. As by the multiplicity of colonies which were dotting its surface, its resources were being developed, it is not at all surprising that the cupidity of individuals and nations was excited to obtain as large a share of these benefits as possible.

It was natural also that the French, who were among the earliest explorers and settlers of the continent, should feel that they had a special claim to, at least, a generous share of the New World. As the French, at that time, had settlements in Canada and in Louisiana, the Governor of Canada projected the bold enterprise of connecting these widely separated colonies by a chain of forts, extending along the Ohio and Mississippi rivers, and occupying, in some places, lands already claimed by the English. Some few years previous to this, there had been grants of territory, west of the Alleghanies, made to an association called the 
Ohio Company. In order to increase their facilities for trading with the Indians, this Company erected a number of posts extending between the colonies on the Atlantic coast and the Ohin river. To these points the Indians were accustomed to bring their furs and exchange them for English toys and manufactures. When the Canadian governor commenced the construction of his chain of forts, by which he intended to bind all this vast country to the throne of France, these trading-posts of the English presented obstructions. Not only must they, as points of English jurisdiction, be removed out of the way, but as they occupied important locations, and were known to the different tribes of Indians, they must be destroyed, or be converted to the use of the French. Accordingly, these trading-posts were attacked by the French, taken, and pillaged, and the traders made prisoners. Other positions were also selected and fortified, in order to keep open a communication between Quebec and New Orleans, along the line of the Alleghany, Ohio and Mississipli rivers. This led to an open rupture between the two nations, and a war was the consequence. In this war Maryland took an active part. She sent forth her brave sons, organized into companies of rangers and frontier guards, to assist in the protection of the exposed border settlements, which lay open to the first attacks of the enraged enemy. In 
September, 1753, Captain Dagworthy, Lieutenants Forty and Bacon, having under their commands two companies, departed from Annapolis, for the endangered western frontier. The next year some companies united with those of North Carolina aud Virginia in an expedition against Fort Duquesne. Delay ensued in consequence of the small number of the troops, as compared with those of the enemy. Vigorous measures were adopted to increase their number, and insure the success of the enterprise. All the forces which were raised to march against the French on the Ohio were placed under the command of Governor Sharpe of Maryland. As the number of troops was not sufficiently large, the General Assembly of Maryland was convened, and enacted a law to encourage the enlistment of troops, in which was the provision that, if any citizen of the province received wounds which destroyed his ability to support himself, he should be maintained at the public expense. At a subsequent session held in February, the General Assembly passed laws to regulate the transportation of the military stores, and the mode of quartering the soldiers upon the inhabitants. They also prohibited, by serere penalties, every inhabitant from furnishing the enemy with provisions or any material for war.

While these preparations were in progress for the anticipated struggle, the hearts of the colonists 
were greatly cheered by the arrival from Great Britain of General Braddock with two regiments of regular troops. The confidence of the colonists in the success of the expedition was now fully established; it seemed to them that all that was wanting to drive the French home, or to whiten the fields with their bones, was the march of the English army to the scene of the coming conflict. But although the enthusiasm of the people was great, yet there was great reluctance on their part to furnish horses, teamsters and wagons for the transportation of the military stores and material of all kinds to the scene of action. Many, however, were pressed into the service, and many were hired. Benjamin Franklin, with great patriotism, hired a hundred and fifty wagons by giving his own bonds to indemnify the owners against loss. This generous movement subjected him afterward to great inconvenience, as many of these wagons were lost or destroyed.

As Braddock was fearful that the French would intrench themselves in large numbers at Fort Duquesne, now called Pittsburg, he considered it a matter of considerable importance for him to press on, and, if possible, surprise the enemy and cut them off. He accordingly selected twelve hundred men, and pushed forward, leaving the remainder of the army to follow more at their leisure. George Washington, who bore the rank of colonel, and who had 
had some experience in actual conflict with the Indians, accepted an invitation from General Braddock to become his aid-de-camp and one of the members of his military family. He therefore accompanied Braddock on this memorable and fatal enterprise.

The army made slow progress toward the field of operations. The roads being new and rough, the usual number of horses were unable to draw the wagons, so heavily were they loaded. To hasten their march, it became necessary to leare behind all superfluous baggage, and take with them only those things that were absolutely necessary. The army, in two divisions, pressed on, General Braddock being with the adranced portion. Unfortunately Colonel Washington was taken down with a violent fever which threatened his life. The physician was alarmed. Braddock ordered him to pause in his march, and go no further until he recovered. It seems as if Washington was not particularly pleased with this order, for the general gave him "a solemn pledge that he should be brought up to the front of the army before it should reach the French fort." * With a wagon for his hospital, he was under the physician's care nearly a fortnight, at the end of which period he was enabled to advance, though very slowly and with great suffering, in consequence of the incessant jolting of the wagon over the rough 
roads. He succeeded, however, in reaching Brad dock at the Youghiogeny river on the evening preceding the battle.

The troops were now in fine spirits. They were within a few miles of Fort Duquesne, and felt fully confident that in a few hours they would be its master.

Early on the 9th of July, 1755, the army, with all their train, crossed the river and continued their march along the southern shore of the Monongahela. "Washington was often heard to say during his lifetime, that the most beautiful spectacle he erer beheld was the display of British troops on this eventful morning. Every man was neatly dressed in full uniform; the soldiers were arranged in columns, and marched in exact order; the sun gleamed from their burnished arms; the river flowed tranquilly on their right, and the deep forest overshadowed them with solemn grandeur on their left. Officers and men were equally inspirited with cheering hopes and confident anticipations.". They had crossed the river once, but about noon they were obliged to pass over it again. About a mile or so from the shore, on the opposite side, was a hill covered more or less with trees. Up this hill passed the road that led to the fort. All the army safely crossed the river. They were then organized into three divisions. Three hundred, under Colonel 
Gage, constituted the advance party, and were sent on ahead. The next consisted of two hundred, after which came General Braddock with the main body of the army, the artillery, and all the baggage.

Some distance intervened between these divisions. Haring crossed the river without experiencing any embarrassment from the enemy, they cherished the hope of reaching the fort without opposition. Not a single foe was any where to be seen. To all appearance the country was as uninhabited as on the morning of creation. But appearances were deceitful." A numerous, courageous, and blood-thirsty enemy were then in front of them, watching every movement, and waiting only for a farorable moment to indicate their presence by sending among the unsuspicious soldiers their iron-messengers of death. About one o'clock, as Colonel Gage's division were ascending the hill, the whole army were startled by hearing a discharge of musketry. A shower of balls was poured into the front of Gage's company, doing dreadful execution. The enemy were invisible. The blue smoke rising up after every discharge, revealed that the firing came from the trees. The soldiers, taken by surprise, and attacked so rigoronsly by an unseen foe, were panicstricken. They fired into the woods at random, but without producing any execution. General Braddock pressed hastily forward with his troops to 
support them, but before he reached them, Gage's men retreated, and fell back upon the artillery, which was coming to their aid, and threw the

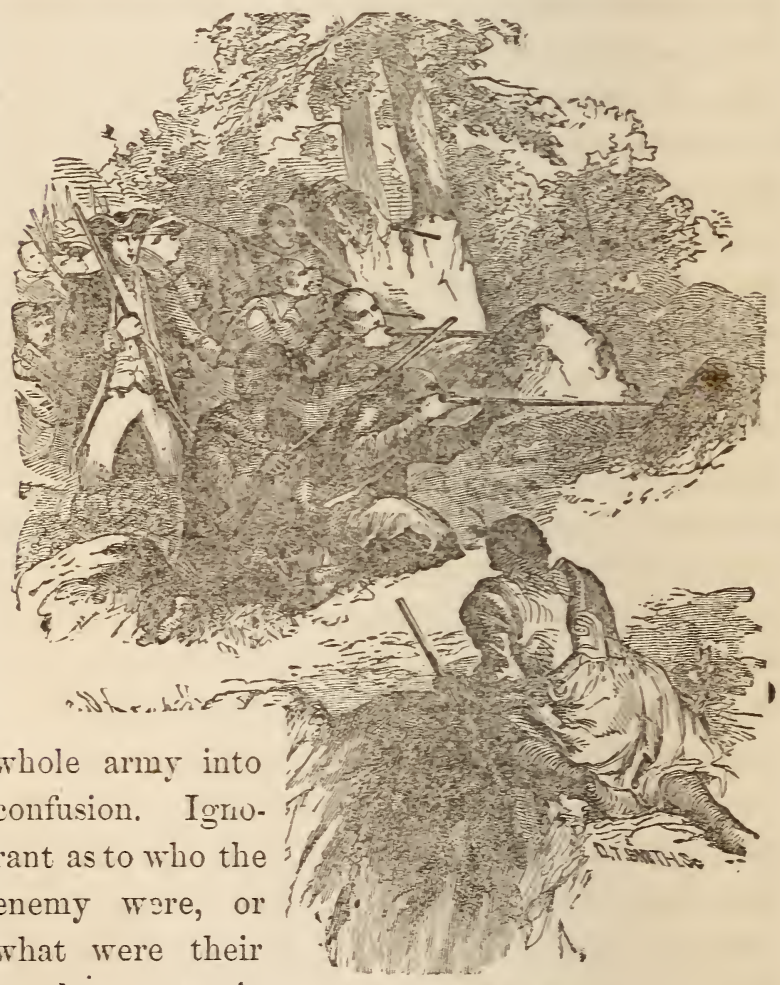

number, or in

IIDIAX AMBCSH.

what way they

could be effectually reached, and seeing their offcers and comrades falling around them, at erery 
discharge from their mysterious foe, they became so panic-stricken that they huddled together like frightened sheep when wolves are prowling around them; they fred their guns at random, shooting down more of their own company than of the enemy. The cool and the excited efforts of the officers to restore order were equally unsuccesstul. No motives, no appeals, no commands were, by any considerable number, heeded, if we except the provincials from Tirginia, who deserve the credit of exhibiting greater coolness and discretion than any others. If their example had been imitated by all the rest of the army, they might have driven the enemy before them, taken possession of the fort, and returned home in triumph. These Virginians adopted the Indian mode of warfare. Each man betook himself to a tree, from behind which he fired, whenerer an arm, head, or any portion of an enemy could be seen. But Braddock seems to have despised this skulking mode of battle. It was at variance with the rules of his profession. He therefore forbade it, and busied himself in rain efforts to form his men, according to the rules of military tactics, into regular platoons and columns. But while he was engaged in these futile endeavors, the French and Indians, in the concealment of ravines, and from behind rocks and trees, were carefully singling out their victims, and deliberately shooting 
them down, "producing a carnage almost unparalleled in the history of modern warfare." Within three hours after this army had crossed the river, with such hopes of success, more than half of them were either killed or wounded; among the latter was General Braddock himself, whose wound soon after proved mortal.

"De Haas, in his History of Western Virginia, maintains, as an unquestionable point of history, that Braddock was shot by one of his own men, by the name of Tom Fausett. Braddock had issued a foolish yet positive order that none of the troops should protect themselves behind trees. Regardless of this, Joseph Fausett, a brother of Tom, had so posted himself, which Braddock perceiving; rode up, and struck him down with his sword. Tom saw his brother fall, and immediately drew up his rifle, and shot Braddock in the back. The ball was stopped in its passage through the body by a coat of mail in front. Tom Fausett is said to have died in 1828, at the great age of one hundred and fourteen years. The sash of General Braddock (in which he was borne from the field) was presented in 1846 by a gentleman of $\mathrm{New}$ Orleans, into whose possession it had come, to General Taylor. It was composed of red silk, and the date of its manufacture was interwoven-'1707.' The blood of Gene- 
ral Braddock had left marks upon it of deep discoloration." *

It was a remarkable circumstance, and beautifully illustrative of a superintending Proridence, that Colonel Washington, though he had not recovered from his illness, was constantly moving about the theater of action, exposing himself to the thickest of the fire, and exhibiting, on all occasions, the most admirable courage. Being aide-de-camp to the general, it was his duty to carry his orders to the subordinate oficers in all parts of the field. This made him a conspicuous mark to the enemy, who did not fail to take advantage of it. In a letter to his brother he says: "By the all-powerful dispensations of Providence, I have been protected beyond all human probability or expectation; for I had four bullets through my coat, and two horses shot under me; yet I escaped unhurt, although death was leveling my companions on every side of me." The work of Washington was not done. He was there receiving experience and a training to fit him for greater achievements, and a more glorious career at a future period. The sererity of the engagement may be inferred from the fact that out of eighty-six officers, twenty-six were killed, and thirty-seren were wounded, while the killed and wounded of the soldiers amounted to seven hundred

* Goodrich's History of the United States.

$$
\text { i* }
$$


and fourteen. Both of the other aides-de-camp of Braddock were wounded; and it seems almost miraculous that Washington escaped. About fifteen years after this battle, Washington, in company with an intimate friend, traveled to the West. While in the vicinity of the junction of the Great Kenawha and Ohio rivers, they were visited by a tribe of Indians, over whom presided a venerable chief. This aged chief told them that having been informed of the approach of Colonel Washington to that part of the country, he had come a long journey on purpose to see him, and then assigned as a reason that, during this very battle of which we have given an account, "he had singled out Washington as a conspicuous object, fired his rifle at him many times, and directed his young warriors to do the same, but to his utter astonishment, none of their balls took effect. He was then persuaded that the youthful hero was under the special guardianship of the Great Spirit, and immediately ceased to fire at hirr. $\mathrm{He}$ was now come to pay homage to the man who was the particular favorite of Heaven, and who could never die in battle." 


\section{CHAPTER XII.}

Sarages offer their Serrices-The Offer unwisely Rejected-Washington's Fame-Daries' Allusion to him Prophetic - Thirst for Blood-The Moravians attacked-Dreadful State of Things-A marvelous EscapeScalp taken from a living Head-Great Panic-Reward of Ten Pounds for an Indian's Scalp.

The question naturally arises, how happened it that the army of General Braddock was allowed to be led into an ambush, when it was well known that that was the Indian mode of warfare, against which he ought to hare been particularly on his guard? The true answer to this question derelops an undesirable trait of character in the commander.

While the army were on their march to Fort DuQuesne, a body of Indians made their appearance, and offered to take sides with the English in the approaching conflict. Washington, who well knew that under certain circumstances they would be able to render important services in the battle, earnestly urged General Braddock to accept of their offer. The General did so, but it was with such cold indifference, as to make a decidedly unfavorable impression upon these wild volunteers. This 
impression was deepened to so great a degree by the subsequent neglect which the Indians experienced from their new friends, that they soon all withdrew. They did not, however, go far, for on the evening before the battle they showed themselves again, and a second time offered their services. Washington again endeavored to influence his commanding officer to receive them. He told him of the character of Indians, their practice of laying in ambush, and of fighting from behind trees, and dwelt on the importance of employing these volunteers as scouts to go ahead and reconnoiter the woods and ravines, and in this manner discorer any ambuscade that might be in waiting for them. But Braddock, flushed with confidence in the courage of his own troops, and disdaining the assistance of these half-naked and ignorant savages, in a decided manner sternly refused to accept of their offer. This unfortunate decision sealed the fate of the following day. For if Washington's advice had been followed, and these Indians, or a portion of them, had been employed as scouts to examine the ground in front of the advancing army, they would have discovered the ambush, and, by preventing the surprise, would, it is highly probable, have secured the victory to the English. But through the foolish and haughty arrogance of Braddock, they were repulsed, and the consequence was a most 
bloody and disgraceful defeat. This, however, resulted in no loss of fame to Washington. His fearlessness, decision, and tact, in the trying emergency of the battle, were witnessed by his brother ofilicers and soldiers, who commended him in the strongest terms. He gathered laurels from the same field where his commander received only dishonor and death. So surprising was his escape from the many perils to which, in that trying conflict, he was exposed, that it was deemed worthy of special allusion in a sermon preached by Rev. Samuel Davies, not long after, whn used the following language, which, to say the least, approximates to the prophetic. After an appropriate commendation of the soldier-like qualities which were exhibited on that memorable occasion by the Virginia troops, he added, "As a remarkable instance of this, I may point out to the public that heroic youth, Colonel Washington, whom I can not but hope Proridence has hitherto preserved, in so signal a manner, for some important service to his country." * How well this prediction was rerified, the subsequent history of Washington has shorn.

In this engagement the number of the enemy was nearly nine hundred, two thirds of whom were Indians. Fortunately for the English, so eager were the victorious army to secure the rich spoils * Sparks's Life of Washington. 
of the conquered, and the scalps of their dead, that, instead of pursuing the English, and cutting them down on their retreat, as they might have done with dreadful effect, they lingered upon the field of carnage, to gather whatever their cupidity or revenge desired. Still, so great was the panic which had seized the English, that they seemed to have retreated with as much dismay as though the Indians were howling in close pursuit. At the order of Colonel Dunbar, the baggage and stores were destroyed, and the wagons in which they were carried were used to convey the wounded. He retreated to Fort Cumberland, and, before long, marched to Philadelphia. So unpropitious did the prospects of the war seem that, though it was then midsummer, he went into winter quarters, and, by so doing, left all the frontier settlements exposed to the tender mercies of the enraged and pitiless savages.

As might have been expected, scenes of terrible barbarity were soon witnessed.

The Indians, whatever may have been their motives, manifested a coldness toward that party who were defeated, though they had previously been on friendly terms with them. The Shawanese and the Delawares were in alliance with the English. They had not only been faithful to their white friends, but had frequently expressed a desire to be 
sent by the English for hostile purposes against the French. Such was their love for the excitements and horrors of battle that they declared if they were not employed by the English they would take sides against them. This thirst for blood had been steadily resisted. But now that the English forces under Braddock had been defeated, and a wide field for the gratification of their savage propensities was furnished by the French, they abandoned the English and went over to the former.* While they were in sympathy with the English, they had been treated with great kindness and had conferred. upon them a great number of presents adapted to their tastes and wants. When, therefore, they deserted them and united with their enemies, the indignation of the colonists was greatly excited at the perfidy they thus exhibited; and under the influence of this feeling, the citizens of the province of Pennsylvania, who had conferred these favors upon them, offered, with the consent of the governor, a reward of seven hundred dollars for their heads.

The defection of these Indians was soon followed by the most dreadful barbarities. It is extremely difficult for us, surrounded as we are with all the indications of peace, contentment and prosperity, to realize the deep and wide-spread agitation occa* Gordon's History of New Jersey. 
sioned lyy the horrors of those times. Even the peace-loving Moravians, who had ever treated the aborigines with uniform kindness, were ruthless!y attacked by them, and some of their number cruelly murdered. The state of things among the English may be inferred from the following extracts of letters which were written about that time. One sent from the Union Iron Works, in New Jersey, December 20th, 1755, says: "The barbarours and bloody scene which is now open in the upper parts of Northampton County, is the most lamentable that has, perhaps, erer appeared. There may be seen horror and desolation-populous settlements deserted-villages laid in ashes-men, women, and children cruelly mangled and massacred-some found in the woods, very nauseous for want of interment-some just reeking from the hands of their sarage slaughterers-and some hacked and corered all orer with wounds." This letter, as a confirmation of its statements, gave a catalogrue of serenty-eight persons who had been slain, and of orer forty settlements which had been burned.

Another letter from Easton, written five dars later than the one above, contains the following: The country all abore this town, for fifty miles, is mostly eracuated and ruined. The people have chiefly fled into the Jerseys. Many of them have thrashed out their corn and carried it off, with their 
cattle and best household goods; but a vast deal is left to the eneny. Many offered half their personal effects to save the rest, but could not obtain assistance enough in time to remove them. The enemy made but few prisoners; murdering almost all that fell into their hands, of all ages and both sexes. All business is at an end, and the few remaining starving inhabitants in this town are quite dejected and dispirited."

Thus the borders of Maryland, as well as those of neighboring states, being open to the attacks of the Indians, became the theater where were acted, in all their horrid realities, the sickening tragedies of savage war. Even before the disastrous discomfiture of Braddock, a war-party of Indians penetrated the settlements, and by their atrocities filled the hearts of the people with terror. The house of $\mathbf{M r}$. Williams, which was situated in Frederic County, was visited by them, and, true to their nature, they commenced a work of carnage which was not finished until twelve persons of various ages were murdered in cold blood. After Braddock's defeat, a company of settlers, believing themselves to be unsafe in their own dwellings, attempted to escape to Fort Cumberland. On their way they were met by a party of Indians, who attacked them and slew fifteen; the original number being eighteen, three only escaped. Of these, one was a boy, who had an 14 * 
extremely perilous deliverance. He was struck by the Indians and fell. One of these demons incarnate approached him, perhaps, the very one who struck him-and finding him senseless-deliberately drew his knife, cut a small circle round the top of his head, tore off this circular piece of skin, which is called the scalp, and left him for clead. But the boy afterward revived, and though he suffered much pain, he succeeded in reaching the fort.

So great was the panic which was excited throughout the colony, that even the inhabitants of the large towns were fearful of a midnight attack. A writer in Green's Gazette, published at that time, says that the Indians were but a short distance from Annapolis, and "that so entire was their defenseless situation that even a small party of twenty or thirty Indians, by marching in the night and skulking in the day time, might come upon them unawares in the dead of night, burn their houses, and cut their throats, before they could put themselves in a posture of defense." This writer, perhaps, took counsel only of his fears, for others believed that "there was no more danger of Annapolis being attacked by the Indians than I.ondon." The apprehensions of the people were soon allayed by the return of sereral volunteers from the West, who stated that they had seen no Indians on the way except one, and "' that he was 'very quiet,' for they found him clead." 
The state of the colony during this trying year may be inferred from the fact that more than twenty of the least protected plantations were destroyed, and the families of the planters either murdered by the blood-thirsty enemy, or carried away into a hopeless captivity.

In order to put the country in a proper state of defense, by the erection of forts and blockhouses at the most expesed points, the Legislature of Maryland, on the $22 \mathrm{~d}$ of March 1756, passed a bill, in which provision was made for raising forty thousand pounds for these purposes, and also to provide for the enlistment and payment of troops. It was directed that ten pounds should be paid to any individual who would produce the scalp of any hostile Indian; the bloody skin being regarded as evidence that its owner had been recently slain. It was slow work, however, to extirpate the Indians in this manner. Small parties were sent out from the colonies, who would occasionally fall in with a band of marauding Indians, and then a conflict would ensue in which some on both sides would be slain or wounded. 


\section{CHAPTER XIII.}

Design of the French-Crown Point-Johnson and the Indian Chiet Hendrick-Baron Dieskau-Indian Nude of Numbering-Indian Battle -An eloquent Indian Chief-Important military Principle-Effects of Delay-Battle of Lake George-Death of Baron Dieskau-Retreat of the French-Effects of the Victory-Johnson highly honored-His selfish Meanness-A true Principle.

The persevering design of the French to obtain possession of large portions of the American continent, south of Canada, notwithstanding the defeats with which their armies had met, was further evinced by their subsequent military operations. In 1731 they erected a fort at Crown Point, on the southwestern shore of Lake Champlain, in the territory of the Indians known as the Six Nations, who were the allies of, and under the protection of the English. This was almost equivalent to an invasion of English soil. It attracted but little attention, and excited no alarm among the English at the time, but afterward it was the occasion of a bloody conflict.

By 1755 so serious had become the encroachments of the French that vigorous measures were necessary to arrest them. Accordingly between five and six thousand troops, chiefly from New England and 
New York assembled at Albany, an inconsiderable town on the Hudson. They were placed under the command of an Irishman of the name of William Johnson-a man distinguished for great muscular power, mental energy, and a bold, enterprising spirit. A prominent reason why he was appointed, arose from his influence with the Six Nations, whom, it was supposed, he would induce to unite in the expedition. In accordance with this expectation he prevailed upon Hendrick, one of their leading chiefs, to accompany them with three hundred of the wild warriors of his tribe.

Of this chief the following anecdotes are related illustrative of his character: At the time it was in contemplation to send a detachment against Dieskau, the number of men to compose the detachment was mentioned to Hendrick, and his opinion was asked as to whether there were enough. $\mathrm{He}$ replied with Indian brevity, "If they are to fight they are too few; if they are to be killed they are too many." The number was at once increased.

Johnson suggested that the detachment should be divided into three parties. To this Hendrick was averse, and to express in an impressive manner his opposition, he took three sticks, and putting them together said to him, "Put these together and you can not break them; take them one by one and you will break them easily." The hint was not lost, and 
"Hendrick's sticks sared many of the party and probably the whole army from destruction."

General Lyman was the second in command. While Johnson was busily engaged in collecting

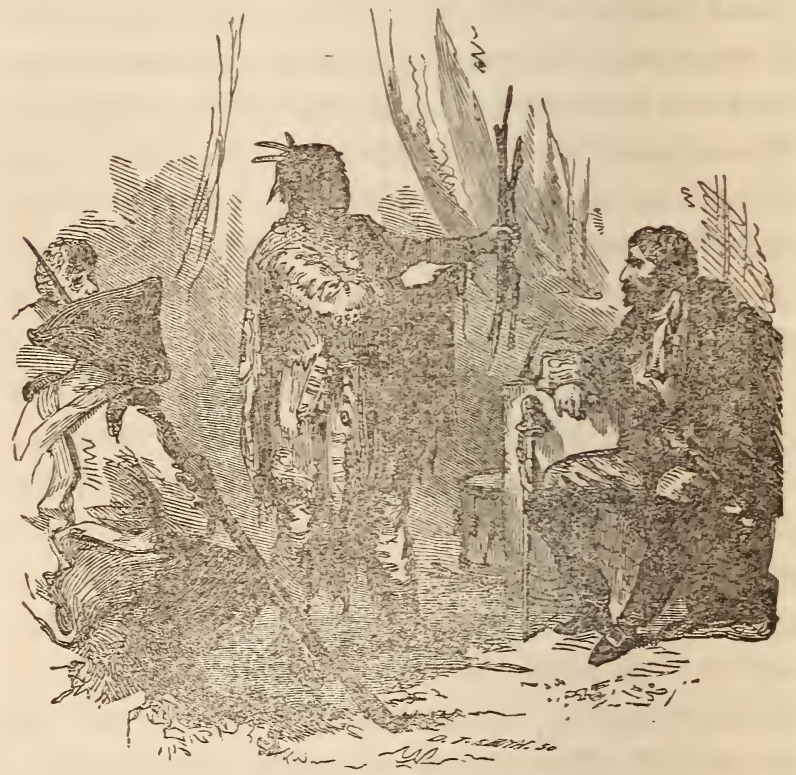

HENDRICK AND THE STICKS.

arms, ammunition and military stores at Albany, Lyman with the troops was industriously laboring to erect a fort at what was termed the "Carrying place," between Hudson river and Lake George, about sixty miles from Albany. It receired the name of Fort Edward. Johnson, after finishing his 
collection of stores, joined his army and, after leave ing a part of it to garrison the new fort, he pushed on to meet the enemy. It was his intention to reduce first the fortifications of Ticonderoga, but receiving the alarming tidings that a strong body of French and Indians were approaching toward him, under the command of the able and experienced Baron Dieskau, he was compelled to abandon this design, and place himself on the defensive. Dieskau, knowing that the army of the English were inferior to his own, calculated upon an easy victory over them, and then he intended to take Albany and lay waste the various neighboring settlements of the English. Unfortunately for Johnson he was unable to learn the probable number or position of the enemy. His Indian scouts, from whom he derived all his information, were unable to express with decision any large numbers. When asked how many, they would point to their hair, or to the stars, to signify a large number, but whether they meant that there were five hundred or ten thousand it was impossible to tell. Johnson was not to be intimidated by rumors of a large army of the enemy of uncertain numbers. Taking counsel from his courage rather than from discretion, he detached a thousand of his brave men, under the command of, Colonel Ephraim Williams, together with two hundred Indians under the Mohawk chief Hendrick, to 
intercept the French, and, if possible, drive them back. This detachment marched forward upon their perilous enterprise with more boldness than prudence. For Dieskau had judiciously placed his men in such positions that they formed a perfect ambuscade. He had arranged the French and Indians on both sides of the road, behind rocks, bushes, trees and whatever else would afford protection, so that they were effectually concealed from the enemy. The English army steadily advanced until they were caught in the ambush. "Whence came you ?" said an Indian on the French side to Hendrick. "From the Mohawks" he replied. "Whence came you?" "From Montreal" was the answer. The battle now began. A few shots fired by the advanced companies indicated to the whole of the two armies that they had met the enemy. The conflict soon became general. Reports of musketry were heard from behind every rock and tree. Warriors on both sides fell without knowing by whom they were wounded. Skill, caution and bravery were displayed by both parties. As the French were the most numerous, and as they were endeavoring to surround the Americans, in which, if they had succeeded, they would soon have slain or captured the whole of them, it became necessary for the Americans to retreat. This was judiciously and successfully accomplished, under the command of Nathan Whiting. There 
was no panic-no rout in this retreat. So far from it that the retreating party repeatedly rallied, turned and fired upon their pursuers. The loss to both armies was considerable. On the American side Colonel Williams and the chief Hendrick were both slain. Hendrick was one of nature's noblemen. " $\mathrm{He}$ had lived to this day with singular honor, and died fighting with a spirit not to be excelled. He was at this time from sixty to sixty-five years of age. His head was covered with white locks, and, what is uncommon among Indians, he was corpulent. Immediately before Colonel Williams began his march, he mounted a stage and harangued his people. He had a strong masculine voice, and it was thought, might be distinctly heard at the distance of half a mile, a fact which has diffused a new degree of probability over Homer's representations of the effects produced by the speeches and shouts of his heroes. Lieutenant Colonel Pomroy, who was present and heard this effusion of Indian eloquence, said that although he did not understand a word of the language, yet such was the animation of Hendrick, the fire of his eye, the force of his gesture, the strength of his emphasis, the apparent propriety of the inflections of his roice and the natural appearance of his whole manner, that himself was more deeply affected with this speech than with any other which he had ever heard. In the Pennsylvania Gazette, 
September 25 th, 1755 , he is styled the famous Hendrick, a renowned Indian warrior among the Nohawks, and it is said that his son, being told that his father was killed, giving the usual Indian groan upon such occasions, and suddenly putting his hand on his left breast, swore that his father was still alive in that place, and that here stood his son."*

On the part of the French, M. St. Pierre, who had all the Indians under his command, was slain.

Nothing is more important after a victory than to follow up a retreating army with vigor, without giving them time to pause and intrench themselves, or prepare for another engagement. It is the general testimony of historians that if the French commander, Dieskau, had adopted this method, after the defeat of Colonel Williams, he might have destroyed, or hopelessly scattered, the whole of the army under Johnson. But he did not. He paused sufficiently long for the confusion of the retreat to subside, and for Johnson to prepare to meet him. The consequence was, that when the French made their attack upon the whole force under Johnson (who were established on the banks of the beautiful Lake George, protected by some cannon, which they had had time to bring up, and of which Dieskau was ignorant), they met with such a warm reception as soon caused them to repent of their

* Dwight's Travels. 
temerity. Johnson had felled some trees, with which he had constructed a breast work for a portion of his men. It furnished, however, a very imperfect protection. The French advanced along the road in regular order, but when Johnson poured into them the unexpected fire of his cannon, the Canadians and the Indians fled and betook themselves to the shelter of the trees and the rocks. Dieskau was surprised and indignant at their conduct. Still, acting upon his own motto "Boldness wins," he made a grand central attack with his regulars, which was kept up with courage and spirit several hours. But they could not stand before the artillery. Johnson was wounded soon after the battle began, and was obliged to be carried to his tent, leaving the command to General Lyman, who conducted the defense with great boldness and vigor, and eventually succeeded in repulsing the French with great loss. Nearly all the French regulars fell before the well-directed fire of the English. 'The brave Dieskau was wounded three times, but refused to leave the field. When two Canadians approached to perform the humane office of bearing him to his tent, one of them fell dead by his side, pierced by a ball, the other he sent away. He then had his military dress placed near him, and seated himself on an old stump, where he could hear soldier's music-the 
whistling and rattling of balls as they flew beside him. Here he was found. "While feeling for his watch to surrender it, one of the soldiers suspecting him to be in search for a pistol, poured a charge through his hips, and he was conducted a prisoner to the English camp." He was afterward carried to England, where he died of his wounds. The retreat of the French was very disorderly. There fell in the engagement about two hundred and twenty slain, and about one hundred wounded. As the French were not immediately followed in their retreat, they paused about four miles from the camp. Here, while they were preparing to refresh their exhausted nature with a meal, they were suddenly attacked by some two hundred men of New Hampshire, under Captain McGinness, and so completely put to flight that they left the whole of their baggage and ammunition a prize to their victors. In this action the brave McGinness fell, mortally wounded. This victory at Lake George was of great importance to the English. The defeat of Braddock had filled the colonies with sadness and despondency. Some successful engagement was necessary to restore them to their accustomed buoyancy and confidence. When, therefore, the intelligence of this defeat of the French, was diffused among them, it was like the lifting of a dark cloud. Fearfulness was banished, and joy and hope once more restored. 
When the account of the victory reached England, the House of Lords regarded it of such consequence that, in a beautiful address, they passed honorable encomiums upon the little army as "brave and faithful." Johnson was honored with the dignity of a baronet, with a grant from Parliament of five thousand pounds, and in addition thereto, he was appointed Superintendent of Indian Affairs. As Johnson was wounded, and obliged to retire from the field, in the early part of the engagement, leaving the responsibility of conducting the battle with General Lyman, by whom it was led to a successful issue, it seems remarkable that such great distinction and emoluments should have been conferred upon Johnson, to the neglect of the other officers. The reason of this, may, perhaps, be found in the fact, that in Johnson's dispatches to the English government, giving an account of the victory, he "assumed the whole merit of it to himself," and thereby robbed the other officers of their proper share. The consequence was that their claims received no attention in England. The meanness of such conduct on the part of Johnson, was unatoned for by all the bravery and energy he possessed. The true principle which should be recognized by all commanding officers in their dispatches, giving an account of military engagements, is that of rendering " honor to whom honor is due." 


\section{CHAPTER XIV.}

Marquis de Montcalm-Forts at Oswego-Tiolent Midnight Attack-Fort Ontario taken-Colonel Mercer killed-No Aisl to be obtained-The English capitulate to the French-Terms of Capitulation-Are shamefully violated-Montcalm destroys the Forts-Lord Loudon's Expedition-Montcalm's Barbarity-Munro's sad Discovery-The English yield to Montcalm-Terms of Submission-Willful Deception--Indignation of the Savages-Their horrid Cruelties-Effects of the Fall of Fort William Henry-The Massacre attributed to Liquor.

After Baron Dieskau had received his mortal wound, he was succeeded in the command of the French forces, by the Marquis de Montcalm. This brave and energetic officer marched against Oswego, a fort at the mouth of the Oswego River, on the southern shore of Lake Ontario. This fort contained fourteen hundred English soldiers, and a large quantity of military stores. It was strong, being built of stone, surrounded by a wall with four bastions, and was protected by another fort, called Fort Ontario, situated upon a commanding eminence on the opposite side of the river. Montcalm, with an army of five thousand French and Indians, came suddenly upon Oswego. He first invested Fort Ontario, and at midnight of August 12, 1756, he poured a destructive fire upon it, from thirty-two 
cannon, and several mortars and howitzers. The garrison in the little fort replied with becoming spirit. But unfortunately for them their stock of ammunition was very limited and soon exhausted. When this was discovered, the commander, Colonel Mercer, spiked his cannon, and fled with his men to Fort Oswego, which he succeeded in reaching without the loss of a single man. The French then took possession of the deserted fort, from which they opened a heary fire upon the other. Colonel Mercer was soon killed, and a breach made in the walls of the fort. Upon the loss of their commander, the English became disheartened, and were unwilling. to continue the contest. An effort to obtain aid from Fort George, four miles up the river, having failed, they capitulated, and surrendered themselves prisoners of war. It was stipulated that the prisoners should receive no cruelty from their conquerors, that they should be protected from plunder, and should be taken to Montreal. These conditions were most dishonorably riolated.

"It was the duty of Montcalm to guard his engagements from the danger of infringement by his savage allies; and yet he instantly delivered up twenty of his prisoners to the Indians who accompanied him, as victims to their vengeance, for an equal number of their own race who perished in the siege. Nor was the remainder of the captive gar- 
rison protected from the cruelty and indignity with which these savages customarily embittered the fate of the vanquished. Almost all of them were plundered, many were scalped, and some were assassinated.

"In the forts the victors obtained possession of one hundred and twenty-one pieces of artillery, fourteen mortars, and a great quantity of military stores and provisions. A number of sloops and boats at the same time fell into their hands." *

After Montcalm had obtained possession of the two forts, instead of putting them in repair and leaving a garrison for their protection, he leveled them both to the ground. This.he did in order to secure the confidence and permanent co-operation of the Indians of the Six Nations, who were dis. pleased that they had been erected upon their territory.

These disastrous events filled the English colonies with discouragement and gloom. Several expeditions against different points of the enemy's territories, which had been planned, were abandoned or postponed. Fort Edward and Fort Hemry, however, were placed in a state of defense. But the next year, 1757, Montcalm, who had derived enencouragement from the supineness of the English, under the newly-appointed and inefficient gov* Grahame's History. 
ernor, Lord Loudon, marched with nine thousand men against Fort Henry. The garrison of the fort consisted of three thousand English and American troops, under the command of Colonel Mlonroe. As Fort Edward was only fourteen miles distant, with four thousand troops under General Webb, it had been reasonably supposed that it would render assistance in case of an attack upon Fort Henry. This, however, was not done. Montcalm pressed the siege of the fort with great spirit. He had promised the Indians who composed a portion of his army that, in case he captured the fort, they should have abundant opportunity of gratifying their barbarous spirit, by practicing their refined cruelties upon as many of the English prisoners as would equal the Indians slain in the battle. They should also have the privilege of plundering their enemy to their heart's content. Motives like these were admirably adapted to excite all the ferocity of the savage allies, and prompt them to fight like so many demons. He also succeeded in stirring up a high degree of warlike enthusiasm in the breast of the volatile French soldiers.

The siege was continued with vigor for six days. Thousands of well-directed shots were exchanged by the two armies, when Munroe made the sad discovery that his ammunition was failing. As all hopes of assistance from Fort Edward, and from all 
other external sources, were blasted, he was compeHed, reluctantly, to capitulate. The terms of capitulation were, under the circumstances, highly honorable. The conquered garrison agreed not to take up arms against the French for eighteen months, while the victorious Montcalm stipulated, that they should march out of the fort with the honors of war, retain their personal baggage, and be protected from the incensed cruelty of the ferocious savages, by a guard of French soldiers, who should escort them to Fort Edward. If these conditions had been faithfully executed, it would have saved the English from suffering most atrocious cruelty, and would have protected the honor of the French from a foul blot, which now rests upon them. As it was, the English were woefully deceived. For when the Indian allies of Montcalm learned what favorable conditions had been granted to the English, they were indignant, and determined not to abide by them. Hence, so soon as the conquered soldiers marched out of the fort, and yielded up their weapons, the Indians pounced upon them with ruthless barbarity, and with their accustomed fiend-like malice, tore from them their clothing; robbed them of their baggage, and slew, or made prisoners, all who opposed them. About one thousand and five hundred English soldiers were, in this defenseless manner, slain, or subjected 
to the barbarities of an Indian captivity. The Indians who had fought on the side of the English were treated in a still more ferocious manner. They were seized and subjected to the refined cruelty of Indian torture. Of the whole garrison of Fort William Henry hardly one half succeeded in reaching Fort Edward, and they were reduced to a most pitiable condition.

The fall of Fort William Henry filled the English colonies with painful surprise, and the disgraceful violation of the treaty of capitulation by Montcalm's Indians kindled within them burning indignation.

For this massacre, Montcalm must not be censured too severely. He and his officers exerted themselves to prevent it. It was, in part, the effect of rum. Montcalm had képt spirituous liquors from the Indians, but after the capitulation of the garrison they obtained it from the English, and under its maddening effects they rushed upon the prisonars and committed the barbarities we have described. This, however, does not excuse Montcalm for holding out to the Indians motives of revenge and plunder, in order to excite them the more ¿itensely against the English. 


\section{CHAPTER XV.}

Pitt favors Liberty-Three important Expeditions-Attack upon Louisburg-Landing in a Storm-Brave Attack and Defense-American Gibraltar-Bombardment-The City taken-Great Joy in EnglandSoldier's Wit-Disappointment in France-French Commander degraded-Mnntcalm at Ticonderoga-His Intrenchments-Abercrombie on Lake George-A Battle in the Woods-Lord Howe slain-Assault of Ticonderoga-The Repulse-English want Cannon-Disheartening Effects.

WHEx intelligence of the capture of the forts in America, and the further encroachments of the French were known in England, the government saw the necessity of sending over more efficient aid to their feeble colonies. Pitt was called to the head of affairs, as the chief rinister of the government. He was a man of enlarged views, powerful oratory, and great executive talents. He was a friend to liberty, and strongly opposed to all tyrannical or unjust legislation toward the colonies. Being convinced of the inefficiency of Lord Loudon's administration of affairs in America, he had him recalled. He also wrote letters to the colonies encouraging them to raise soldiers, and provide, to the extent of their ability, the munitions of war. He also stimulated the government to aid the colonies by 
sending out large numbers of troops, in connection with a fleet of vessels of war.

During the year 1758 three different expeditions were undertaken by the English. The object of these expeditions was the conquest of Canada. The first was an attack upon Louisburg, a town situated on the eastern extremity of the island of Cape Breton, and garrisoned by thirty-one hundred soldiers, of whom two thousand five hundred were regulars, the rest being militia. The harbor was protected by one fifty-gun ship, five ships of the line, and five frigates-three being sunk across the mouth. On the $2 \mathrm{~d}$ of June the English fleet and army, consisting of twenty ships of the line, fifteen frigates, and ten thousand soldiers, arrived before the town. So violent were the wares, and so well protected was the harbor, that the attempt to land was deemed too dangerous to be undertaken.

But on the 8th of the month this important operation commenced. The first division that landed was under the command of General Wolfe. The boats were well filled, and notwithstanding the surf, which continued to roll with much violence, they adranced toward the land. But they met with obstructions more difficult than the waves. These consisted of a tempestuous storm of bullets, paured upon them by the French from behind their batteries and breastworks, which had been thrown up along 16 
the shore to prevent the landing of the invaders. Wolfe would not allow a gun to be fired in return. But he kept up the spirits of the men by cheering them onward. When they arrived near the land they leaped in the rolling surf, and in spite of a spir-

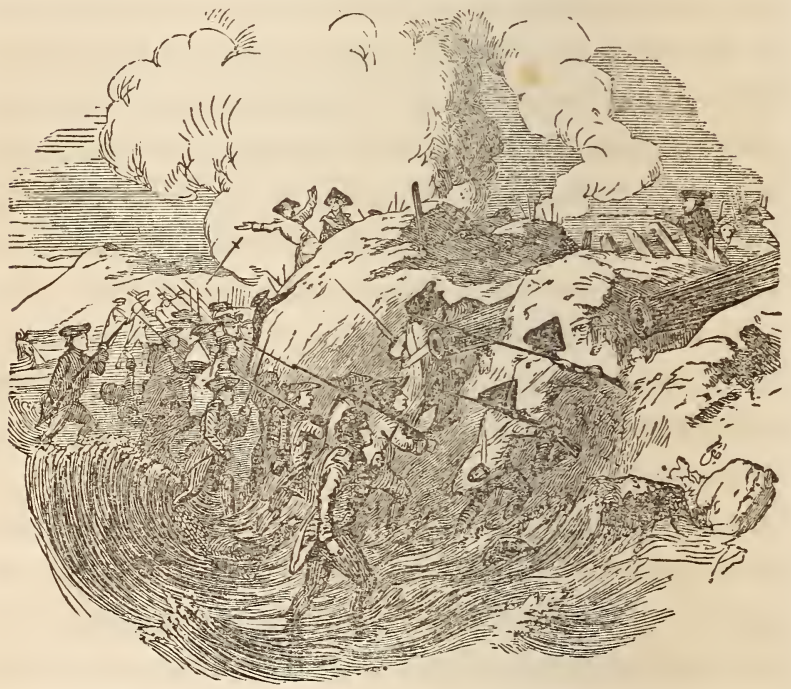

LANOING AT LOUISBURG.

ited fire kept up by the enemy, they waded through the water, reached the shore, attacked the batteries which had been making the waters of the ocean crimson with the blood of the English, furiously assailed those who served the guns, slew them at their posts, or else drove them from their positions, 
and in a few hours successfully invested the town. In this movement, which was conducted with skill and energy, several of the boats of the English, filled with soldiers, were dashed to pieces by the violence of the waves, and many others were upset, throwing their passengers into the turbulent deep.

After the English troops were landed, it became desirable to seize a post in the possession of the enemy, called Light House Point, from which by a welldirected battery the English might greatly annoy the French ships in the harbor, and do effective execution upon the fortifications of the town. General Wolfe was accordingly sent with a detachment of two thousand men to take this point. This was no difficult task, for when the enemy saw him approaching, they abandoned the position and fled. The siege of the town was now pressed with caution, yet with great resolution. The fleet was under the command of Admiral Boscawen, and the soldiers under Amherst, to whom Wolfe was a subordinate. The garrison of Louisburg was commanded by Chevalier de Drucourt. So-strong were the fortifications of this place, and of such importance was its possession supposed to be, that it was called the American Gibraltar. But it could not stand before the resistless energy of the English. A welldirected bomb set fire to one of the largest French ships, which soon blew up, scattering its burning 
fragments in every direction. This set fire to two others, which were also consumed. The admiral now sent off boats with six hundred men to destroy, or take possession of two ships of the line. Under the cover of night they engaged in this perilous enterprise. One of the ships was aground. This they set on fire, and notwithstanding a violent shower of musket and cannon-balls, which were pouring upon them, they succeeded in triumphantly towing the other away. The English admiral now had command of the harbor. Breaches had also been made in the fortifications that protected the town. The firing was kept up with vigor. The town was reduced nearly to ruins.

By the 25th of July it was apparent to the French commander that it was useless to hold out any longer. The fleet was destroyed, and the enemy controlled the harbor. Of fifty-two cannon, forty had been rendered useless. Longer opposition would only lead to unnecessary slaughter. The Chevalier de Drucourt proposed to capitulate. The terms he offered were rejected by the English, who demanded that the garrison should yield as prisoners of war, or, in case of refusal, be simultaneously assaulted by sea and land. These conditions were so humiliating that the spirit of the French commander revolted at them, but there being no other alternative, he was compelled to yield. By 
this important victory there came into the hands of the English two hundred and twenty-one pieces of cannon, eighteen mortars for the throwing of bombs, with an immense quantity of stores and ammunition. In achieving this triumph the English lost about four hundred men, and the French fifteen hundred. The most important effect of this victory was, that it greatly weakened the power of France on the eastern coast of America. For not only was Louisburg, but also Isle Royal, St. John's and their dependencies, at this time surrendered to the English. The island of Cape Breton was also taken, and French authority fell. The inhabitants of Cape Breton were carried back to France in English ships, but the garrison of Louisburg, consisting of more than five thousand six hundred men, were sent as prisoners of war to England, where the news of this important victory excited a high degree of joyous enthusiasm. The French flags which were taken at Lonisburg were used to grace a grand procession in London, from Kensington Palace to the Cathediral at St. Paul's. The assistance of the God of battles was at the same time also recognized. A special form of thanksgiving was prepared and appointed to be read in all the churches.

Amid the roar of battle and of carnage illustrations of wit are sometimes furnished from incidents which, to one unaccustomed to war, would seern to $16 \%$ 
be suggestive of any other feeling than that of cheerfulness. Here is an instance: While commanding the soldiers in the trenches before Louisburg, a bomb from the fort grazed the skull and knocked off the hat of General Lawrence, but without inflicting a serious wound. This furnished occasion for a humorous remark of Captain Charles Lee. "I'll resign to-morrow," exclaimed Lee. "Why so?" was the reply. "Because," said the wit, "none but a fool will remain in a service in which the generals' heads are bomb-proof."

By this defeat the French government were both pained and chagrined. They had spent an immense amount of money upon the fortifications of the town; but all in vain. They expected much also from the fleet sent to its assistance. So indignant were they at the conduct of Marquis De Gouttes who commanded the fleet on this occasion, and was so unfortunate as to be conquered, that " he was condemned in France to be degraded from his rank of nobility, to have his patent burned by the common hangman, and to be imprisoned for twenty-one years." - The depression of the French was not of long continuance. They were soon called upon to rejoice over a victory which, though of not so much importance as the capture of Louisburg, yet redounded greatly to their honor, and was the means of restoring spirit and enthusiasm to their army. 
After the conquest of Cape Breton, the English next directed their movements against Ticonderoga, situated at the southern extremity of Lake Champlain. A fort had been built on a point of land formed by the lake and a small river, which conducted the water of Lake Horicon into that of Champlain. Here Montcalm, the French commander, was intrenched, with forces numbering over thirty-six hundred. Knowing that the English intended to make a powerful attack upon this place with a formidable army, Montcalm made every preparation to give them a suitable reception. In addition to a high breastwork which was erected, he ordered his men to cut down trees and branches, sharpen the ends, and thickly strew them with their points toward the enemy, so as to entangle them and impede their approach to the fort.

On the 5th of July, 1758, the whole English soldiery, amounting to upward of fifteen thousand men - the largest army from the Old World which had ever congregated in the $\mathrm{New}$-took their departure from their place of encampment on Lake George, and directed their course toward the north. They were commanded by General Abercrombie; under him was Lord Howe, a young officer of great merit, who, by his soldier-like qualities, his courage, decision, good sense, and humanity, had secured the respect of his brother officers, and the affectionate 
esteem of the whole army. In the dawn of the morning, these fifteen thousand soldiers, under the direction of their subordinate officers, embarked in one hundred and thirty-five whale-boats, and nine hundred other small boats of a different craft. Their artillery was borne on rafts, constructed for the purpose. When this fleet of over a thousand boats left the shore, breaking the glassy surface of the beautiful Lake George, and sending the ripples, like so many couriers, in every direction-with their gorgeous banners streaming over their heads, and the shores echoing the strains of their soulinspiring music-they presented a magnificent sight. The soldiers, flushed with recent victory, were sanguine of further success.

After they disembarked, they were arranged into four columns, the British regulars forming the center, and the American provincials the flanks. In this manner they set out toward Ticonderoga, drawing an immense train of artillery, ammunition, and stores after them.

They fell in with an adranced guard of the French, of three hundred men, under the command of De Trépézée, who had been sent to observe the morements of the English. Upon the approach of Abercrombie, De Trépézée left his encampment, and retreated. The English pressed on orer the hills and valleys, and through the woods, as rapidly 
as the natural obstructions of the country would allow. As Lord Howe was advancing with the right central column, he fell upon De Trépézée and his three hundred, who had become bewildered and lost, on their return to Fort Carillon. A severe skirmish at once ensued. The English poured upon these fugitive wanderers a scorching fire, which was returned with spirit. Though attacked so suddenly, the enemy exhibited great promptitude and courage in their defense. Concealing themselres in the bushes and behind the trees, they poured forth successire rolleys of musketry, and came near putting their pursuers to flight. The provincials, who were better acquainted with the mode of fighting adopted at this time by the French and their Indian allies, maintained their ground, and prevented a disastrous retreat. De Trépézée was vanquished. Of his three hundred, some were drowned in a neighboring stream, some slain, and about one hundred and sixty taken prisoners. Iet this victory was purchased at a severe loss; Lord Howe fell in the first of the engagement and died almost immediately. His loss was a great affliction to the army: he was the pride and confidence of the soldiers. Great reliance was placed upon his judgment, skill, promptitude, and energy in the approaching attack upon Fort Carillon at Ticonderoga. His fall, therefore, was followed by great 
gloom and depression in the army. It was, also, deplored throughout the American colonies. The colony of Massachusetts voted to ereet a monument to his honor in Westminster Abbey.

The night following this skirmish the English passed in the woods.

On the 8th, General Abercrombie sent his chief engineer to reconoiter the French position. $\mathrm{He}$ did so, and brought back word that their defenses were weak, and would present but little obstruction. Other officers of better judgment differed from him in opinion. However, Abercrombie resolved upon making an attack. Without waiting for his cannon to be brought up, which would have rendered essential assistance, he gave orders for an immediate assault. His army approached in three lines. Montcalm, the French commander, when he saw them advancing, threw off his coat and ordered his men to retain their fire till further orders. The English came forward in three columns, so as to attack three diferent points simultaneously. But they soon found themselves impeded and thrown into confusion by the trees and pointed branches which the French had strewn before their defenses. At the command of Montcalm, the French now poured upon the besiegers a galling fire from muskets and swivels, which produced great execution. The offi- 
cers and men who were entangled in promiscuous confusion among the branches, logs and rubbish, which the French had strewn in front of their breastworks, furnished so many marks for the besieged to aim at; the consequence was, large numbers of them fell. Nothing daunted, the English came again and again to the attack with great courage and intrepidity. Until late in the afternoon were these assaults continued, but all in vain. If Abercrombie had waited until his cannon had arrived, before he commenced the attack, or if he had continued the conflict until they were on the ground, it is believed that he would have subdued the fort. There were heights in the vicinity. from which he could have poured into the fort a destructive fire of heavy balls that would have reduced it to ruin in a short time. Even Montcalm, himself, said, "If I had to besiege Fort Carillon, I would ask for but six mortars and two pieces of artillery."

Abercrombie unwisely attempted the reduction of the place without cannon, and when he found that this was impossible, instead of postponing further measures until his artillery arrived, he ingloriously ordered the siege to be raised and his army to retreat. So great was the confusion and the ignorance of the English respecting the position of their own troops, that they fired upon their friends, producing more execution than among the enemy 
The engagement continued four hours, during which time the English lost in killed and wounded, one thousand nine hundred and forty-four, and then precipitately retreated to the boats on the lake, which they had left at the landing place. The next morning they embarked, leaving the French, who were only about one fourth as numerous as themselves, to glory in their success. This disastrous result of an expensive and magnificent enterprise, from which so much had been hoped, filled the colonies with gloom, and the British court with sadness. The disheartening effects were almost equal to those produced by the defeat of Braddock. 


\section{CHAPTER XVI.}

Activity of the French-Attempt to intercept them-Injudicious SportA Skirmish the Consequence-Putnam a Prisoner to the Indians-Is tied to a Tree to be burned-His Thoughts-His Deliverance-Colonel Bradstreet's Proposition-The Experlition against Fort FrontinacState of Things at Oswego-Attack upon Frontinac-Indian DesertersFrontinac taken-Munitions of War obtained-Armed Vessels seizedThe Fort leveled-The English encouraged.

After the dishonorable retreat of the English from Ticonderoga, and "while Abercrombie wearied his army with laborious idleness in lining out a fort, the partisans of Montcalm were present every where. Just after the retreat of the English they fell upon a regiment at the half-way brook, between Fort Edward and Lake George. A fortnight later they seized a convoy of wagoners at the same place. To intercept the French on their return some hundred ranger's scoured the forests near Woodcreek, marching in Indian file, Putnam in the rear, in front the Commander Rogers, who with a British officer beguiled the way by firing at marks. The noise attracted hostile Indians to an ambuscade. A skirm. ish ensued, and Putnam, with twelve or fourteen more, was separated from the party. His com- 
rades were scalped; in after-life he used to relate how one of the savages gashed his cheek with a tomahawk, bound him to a forest-tree and kindled about him a crackling fire; how his thoughts glanced aside to the wife of his youth and the group of children that gamboled in his fields, when the brave French officer Marin descried his danger and rescued him from death, to be exchanged in the autumn."*

After the repulse from Ticonderoga Colonel Bradstreet proposed to go against Fort Frontinac. This proposal being approved by a council of war, Abercrombie placed under his command about three thousand troops, nearly all of whom were American provincials. His artillery consisted of eight cannons and three mortars. When they arrived at Oswego, where the two forts had stood from which the English had been driven by Montcalm, they found nothing but ruins-the forts having been destroyed, as previously related, by Montcalm. A large wooden cross had been left as a memorial. After viewing the spot with other than pleasant emotions, they embarked in open boats, crossed Lake Ontario, and on the 25th of August landed near Frontinac. The soldiers soon went to work erecting their batteries. So near to the fort were they planted that, when they opened upon the French, almost every * Baneroft. 
shot took effect. The commandant finding that resistance would prove unavailing, surrendered at discretion on the second day. The Indian auxiliaries of the French, probably believing that the fort would be obliged to capitulate, deserted, and made their escape, so that when the place was taken, Bradstreet found only a hundred and ten prisoners-a small number to cope with nearly three thousand of the enemy. He also found sixteen small mortars, fortysix pieces of cannon, and an immense collection of various kinds of military stores, provisions, and merchandise. These stores were destined for Fort Duquesne and other French posts. In addition to these he took possession of nine armed vessels, each bearing from eight to eighteen guns. He leveled the fort to the ground, destroyed seven of the vessels, sent two to Oswego, and then took away as much of the stores as his army could carry.

The reduction of Fort Frontinac was as dispiriting to the French as it was encouraging to the English. It inspired the latter with increased energy in their next expedition, which had for its object the subjugation of Fort Duquesne. 


\section{CHAPTER XVII.}

A new Expedition against Duque ne-A new Road proposed- Washington opposes it-The Decision-Washington requests to be in the Front of the Armi-Grant's Folly-Unexpected Attack-Injudicious Conduct of the Highlanders-Panic of the Pennsylvanians-Method of the Marylanders-Conduct of Washington-Grant a Prisoner-Council of War-Going into Winter Quarters-Loyal Hanning-Another Fight -Sad Mistakes--Indian Policy-Indian Deserters-Provincials the best Soldiers-Fort Duquesne taken-Name altered to Fort Pitt-Pay of the Soldiers.

As Fort Duquesne was one of the strongest posts of the enemy in this part of the country, it was considered by the English of great importance that it should be taken from them. Although Braddock's attempt to reduce it had resulted in such a disastrous and fatal defeat, yet the spirit of the colonists was by no means destroyed, nor their desire for its possession in the least degree lessened. As, however, its 'reduction was regarded as a work of great magnitude, and as all the colonies were deeply interested in the success of the enterprise, no one colony was willing to undertake it alone. It being admitted to be a matter of general interest, the various provinces of Maryland, Pennsylvania, Virginia and Carolina, united their forces for its 
overthrow. The army was under the command of General Forbes, assisted by Colonel Washington, who commanded the Virginia forces, and Colonel Dagworthy who led the Maryland soldiers. The whole army numbered some six thousand. It was a fortunate circumstance for the colonists that Mr. Pitt was the controlling genius of the British ministry in England. Being deeply impressed with the value of the colonies, and with the importance of protecting them from the inroads of the Indians and the aggressions of the French, he addressed the colonies upon the importance of union among themselves against the common enemy, and proposed to furnish the soldiers with provisions, ammunition, tents, and weapons, at the expense of the English government. This would throw upon the colonies the responsibility of providing only the clothes and the wages of the men. This proposition was received with gladness, as thè colonies themselves were poorly able to defray the expenses of the campaign.

General Forbes was in favor of cutting open a new road through Pennsylvania to the Ohio for the troops to pass through. To this, Washington was strongly opposed. The old road, by which Braddock had marched, was open, and by that route the army could pass without obstruction; but to prepare a new road through a primeval forest, over 
mountains and across rivers, would necessarily occupy a great amount of time, besides greatly increasing their exposure to ambuscades and sudden attacks of the enemy, under circumstances which would render it extremely difficult to repel them. Washington used every argument in his power to dissuade him from this injudicious measure, but was unsuccessful. Orders were given for the new road to be opened. Although Washington was fully convinced of the bad policy of this morement, and exerted himself in every possible way to dirert General Forbes from it, yet so soon as it was decided upon by his superior officers, he suppressed his own dissatisfaction, and devoted himself zealously to the execution of the plan. He asked the privilege of being placed with the Virginia troops in the advance of the main army, that they might act as pioneers in breaking the way, and as scouts on the look-out for lurking foes. This request was granted, and Washington with his brave Virginians were sent ahead to prepare the way, to guard against surprise, and to provide intrenchments at suitable places where the army might pause in its march. This work of cutting a new road through a wilderness was extremely slow. When they were about tifty miles from Fort Duquesne, winter had set in with its unwelcome attendants of frost, rain, sleet and snow. A council of war was held, which 
decided that it was impracticable to advance any further at present, and therefore operations must cease till spring. While making arrangements to go into their winter encampment, three of the enemy were taken prisoners. They were closely examined respecting the condition of Fort Duquesne, and gave such a statement of its weaknesss, that the decision to go into winter quarters was reversed, and orders were given to push on with as much alacrity as possible.

In the latter part of the month of September Major Grant was sent forward for the purpose of reconnoitering the enemy; he took with him a picked corps of between eight and nine hundred men,* among whom were more than three hundred Highlanders, one hundred and fourteen royal Americans, one hundred and serenty-six Tirginians, ninety-five Marylanders, one hundred and twelve Pennsylvanians and thirteen Carolina troops. Under the corer of night he took up his position on a hill, a short distance from Fort Duquesne. Not satisfied with having taken, unknown to his enemy a strong position, he resorted to other measures which were adapted to initate them and excite them to a desperate defense. In the morning by way of tamt and bravado he ordered the reveille to be beaten upon the drums, and the bag-pipes to be sounded

* Green's Gazette in McSherry's History of Maryland. 
in various places. As soon as the garrison discovered what had been done, a party of Indians sallied from the fort, and stealthily pursued their way under the protection furnished by the banks of the river, until they gained an eminence higher than that which was occupied by Grant. It was not long before they surrounded the English, and opened upon them their fire. The Highlanders adopted the most injudicious method of procedure under the circum. stances which could have been devised. They "were drawn out in close array," which made them a conspicuous mark for the enemy, and on which every discharge of their muskets produced fatal effects. The consequence was that after many of them were slain, the rest retreated. The troops from Pennsylvania. were panic-stricken and fled at the first fire. But the Marylanders and Carolinians adopted the Indian mode of warfare. They betook themselves to the bushes and woods, and under the protection which they furnished, fired at the enomy. Washington unfortunately at that time was two miles in the rear, where he had been ordered to protect the baggage of the army. As soon as the noise of the engagement reached him, he urged his men rapidly on to the scene of conflict to assist Grant. The Indians fought with great vigor. The English were unable to maintain their ground, and after a loss of two hundred and seventy-three 
killed and forty-two wounded they were compelled to flee. The Marylanders, who had exhibited great bravery on the field, with a small number of Virginians performed the responsible and perilous duty of covering the retreat of the army. Nearly one half of the Maryland troops was either killed or wounded. Many prisoners were taken by the Indians, among whom was Major Grant himself.

It will be remembered that at Braddock's defeat before this same fort, the forces under Colonel Dunbar rapidly retreated without pausing at any point to make a-stand, or to retrieve the fortunes of the day. The Indians supposed it would be the same on the present occasion; they did not therefore attempt any pursuit, but contented themselves with what plunder and prisoners they could take from the immediate scene of action. A large number of them withdrew from the fort and returned to their own grounds, notwithstanding the earnest entreaties of the French for them to remain with them. This, as we shall presently see, operated favorably for the English.

The soldiers who had been defeated were an advanced detachment. The main body, under Forbes, was slowly following. On the 5th of November, they reached a military post at Loyal Hanning. They here received the painful intelligence that the advanced guard had been totally. 
defeated. The enthusiasm of the soldiers was checked by these unwelcome tidings. They felt humbled and discouraged. The officers hardly knew what was the luetter course to pursue, whether to continue their march toward the scene of action and meet the enemy, who were flushed and emboldened by their recent victory, or go into winter-quarters where they were. A council of war was held. Owing to the recent defeat, the coldness of the season, the difficulty of the roads, and the danger of being met under unfavorable circumstances by their victorious enemy, it was decided to be the wiser course to bring the present campaign to a close by going into winter quarters. The enemy, who were kept constantly informed of all the movements of the English, being highly delighted with the results of the first engagement, resolved to follow up their success with another attack. For this purpose the French troops, in connection with those Indians who had been persuaded to remain at the fort, were ordered to advance upon the English. They met at Loyal Han. ning, October 12th, and were soon in the midst of a severe engagement. The battle was kept up with great energy on both sides for four hours. The English gained upon the French and Indians, until finally the latter retreated, discomfited, from the field, carrying with them their wounded and their 
dead. This was an important engagement. It banished the despondency of the English, restored to them their courage and energy, and nerved them to the cheerful endurance of other fatigues and conflicts. At the same time it checked the audacity of the French, and sent them back somewhat broken in spirit. The loss of the English in this engagement was sixty-seven killed and wounded, including both officers and men.

In this engagement the Maryland troops came in for their loss. They had one officer and two privates killed, one officer and six privates wounded, and eleven were missing. The slain officer was Lieutenant Prather, the wounded one was Ensign Bell. The number of the enemy that fell was not known, as they were all remored from the field.

The defeated army did not retreat far. Burning with revenge they hung upon the skirts of the English, watching for a favorable opportunity to pounce upon them, and recover their lost honors. Scouts were frequently sent out by the English, to see where the foe was lurking. One of these parties fell in on the 12 th of November with a detachment of the enemy. An engagement at once took place. A party of Virginians who were at hand, hearing the sharp and rapid firing, and suspecting immediately the occasion, came rapidly to the assistance of their friends. But in consequence 
of a dense fog prevailing at the time, they were mistaken for a new detachment of the enemy, and unfortunately fired upon as such, by those whom they had come to help, before the error was discovered. Among the instances of individual prowess which were displayed on that occasion, it is related that Captain Evan Shelly, who commanded the Maryland Volunteers, had a personal encounter with a prominent Indian chief, and succeeded, without any help, in giving him a mortal wound, and leaving him dead upon the field.

As intelligence of this victory was diffused among the colonies, it banished despondency and awakened hope of the successful issue of the campaign. The disheartening effects of the previous defeat subsided, and an increased spirit of patriotic enterprise was developed.

Among the favorable results of this battle was the disgust which was awakened in the minds of the Indians toward the French, with whom they were in alliance. The truth is, the Indians were fighting for pay and plunder. To the interior tribes it was a matter of small consequence whether the French or the English conquered. They were, therefore, willing to take sides with that party who would be the most likely to be victorious, and furnish them with the greatest amount of wages and spoils. When, therefore, the French were defeated, 
their Indian allies felt as if they had espoused the wrong side. They did not obtain so great a number of scalps, nor so great an amount of plunder as they desired. They, therefore, deserted, and left the French to take care of themselves.

One day a prisoner was taken by Captain Ware of the Maryland troops, and brought into camp. According to custom, he was examined in order that from him might be ascertained the condition of the enemy. He gave the pleasing intelligence of the withdrawal of the Indians, and the consequent weakness of the garrison at Fort Duquesne. After the reception of this information, the English commander determined to press on and surprise the fort before it could receive any reinforcements.

The deserting Indians said that they had no diffculty in overcoming the British regulars, but they found it impossible to resist the attacks of the provincials - those companies which were composed of American colonists. This assertion develops an important fact. These "regulars" were soldiers who had enlisted in the English army for pay. They would go any where, and fight any nation against whom they were sent. They had, personally, nothing at stake but their own lives. With the colonists it was far otherwise. They hazarded every thing. While, therefore, it was comparatively easy for the Indians to overcome the "regu- 
lars," they found it almost impossible to prevail against the colonists. This fact shors that men who are fighting for their homes, for the protection of wives, children, and all that is most dear to thern, will exhibit a far greater degree of courage, fortitude, and perseverance, than those who engage in war merely for glory or for pay.

Past experience, as well as the assertion of the Indians, prompted the commander to give the adrance to Colonel Washington with his Virginia provincials, instead of assigning it to one of the imported British officers.

Learing the tents and heary camp equipages behind, the army pressed on as rapidly as possible. With Washington in front, marking out the course to be pursued, attending to the arduous work of opening a new road, preparing the way, and making deposits of provisions for the main army, and with the personal example of the officers, who assisted the soldiers in the work, they succeeded in reaching the fort by the $24 \mathrm{th}$ of November. When the garrison found these unwelcome visitors in their neighborhood, they were alarmed. Being reduced in numbers and in spirit, they had no disposition to attempt holding out against the English, who had just come from a successful conflict. They decided, therefore, to abandon the fort. After collecting the most important articles they should want on 
their retreat, they seized the opportunity, when the darkness of night would prevent detection, and secretly left the fort, fled to the Ohio river, which was at hand, took boats and rowed themselves down the stream. When, on the next day, the English reached the fort, they were surprised and pleased to find it abandoned. There was not much, howerer, there, for the French, as they left, set fire to the place. The smoldering embers which were still smoking when the English came up, showed to what extremity the enemy had been driven. Thus this important position, which had already caused the colonists so much blood and treasure, was now in their possession. The commander resolved that two things should be done: First, that the fort should be repaired, and put in a good state of defense. By the combined enterprise of officers and soldiers, this was soon accomplished. He next resolved that it should receive a new name. As Mr. Pitt, of the British Parliament, had deeply sympathized with the colonists, and had powerfully advocated their cause; and as through his encouragement and assistance, this campaign had been undertaken, it was determined, as a token of the honor in which he was held by the provincials, to call the place Fort Pitt. * Leaving a garrison of two hundred Virginians to protect the fort, the remainder of the army joyfully returned homeward.

* Now Pittsburg. 
The capture of Fort Pitt was a circumstance of great moment in those stirring times. It filled the hearts of the colonists with joy, and imparted to them new life. Governor Sharp deemed it an occasion worthy of being commemorated by a day of public thanksgiving and praise, and he accordingly issued a proclamation to that effect. In addition to this, the Assembly of Maryland, as a testimony of gratitude to the patriotic men who helped to constitute the victorious army, roted to distribute fifteen hundred pounds among them. This was appropriated as follows:-to Lieutenant-Colonel Dagworthy, thirty pounds; to each captain, sixteen pounds; lieutenant, twelve pounds; ensign, nine pounds; and to each non-commissioned officer, six pounds: the remainder was spent for clothing and other comforts for the private soldiers. 


\section{CHAPTER XVIII.}

Indian Deputations-An affecting Duty-Searching for the Dead--A singular Incident-Dreadful Mementoes.-Tragic Scenes-Battle of Niagara -French Defeated-Surrender of the Garrison-No Retaliation-Captive Solliers-Are sent to Alban - -Women and Children sent to Quebec-French communication between Canada and Louisiana destroyed.

After Fort Duquesne was deserted by the French and taken possession of by the English, it was visited by deputations of the various tribes of Indians, who came to form a friendly alliance with the victors. Among these were some who were the adherents of the French at the time of Braddock's defeat, and who were engaged in that battle.

With their assistance General Forbes resolved to search the woods for the unburied corpses of those soldiers, who were slain in that unfortunate campaign, and bestow upon them the appropriate rites of a military interment. A touching account of this affecting service is given in Galt's "Life of West." He says, "After the taking of Fort Duquesne General Forbes resolved to search for the relics of Braddock's army. As the European soldiers were not so well qualified to explore the forests, Captain West, $18 *$ 
the elder brother of Benjamin W est, the painter, was appointed, with his company of sharpshooters, to assist in the execution of this duty; and a party of Indian warriors, who had returned to the British interests, were requested to conduct him to the places where the bones of the slain were likely to be found. In this solemn and affecting duty several officers, belonging to the forty-second regiment, accompanied the detachment and with them Major Sir Peter Halket, who had lost his father and brother in the fatal destruction of the army. It might have been thought a hopeless task that he should be able to discriminate their remains from the common relics of the other soldiers; but he was induced to think otherwise, as one of the Indian warriors assured him that he had seen an officer fall near a remarkable tree, which he thought he could still discover; informing him at the same time that the incident was impressed on his memory by observing a young subaltern, who, in running to the officer's assistance, was also shot dead, on his reaching the spot, and fell across the other's body. The major had a mournful conviction in his own mind that the two officers were his father and brother; and, indeed, it was chiefly owing to his anxiety on the subject that this pious expedition, the second of the kind that history records, was undertaken.

"Captain West and his companions proceeded 
through the woods and along the banks of the river, toward the scene of the battle. The Indians regarded the expedition as a religious service, and guided the troops with awe and in profound silence. The soldiers were affected with sentiments not less serious; and as they explored the bewildering labyrinths of those vast forests, their hearts were often melted with inexpressible sorrow ; for they frequently found skeletons lying across the trunks of fallen trees-a mournful proof, to their imaginations, that the men who sat there had perished from hunger, while vainly attempting to find their way to the plantations. Sometimes their feelings were raised to the utmost pitch of horror by the sight of skulls and bones scattered on the ground-a certain indication that the bodies had been devoured by wild beasts; and in other places they saw the blackness of ashes amid the relics-the tremendous evidence of atrocious rites.

"At length they reached a turn of the river, not far from the principal scene of destruction; and the Indian who remembered the death of the two offcers stopped. The detachment also halted. He then looked around in quest of some object which might recall distinctly his recollection of the ground, and suddenly darted into the wood. The soldiers rested on their arms without speaking. A shrill cry was soon after heard, and the other guides made 
signs for the troops to follow them toward the spot from which it came. In a short time they reached the Indian warrior, who by his cry had announced to his companions that he had found the place where he was posted on the day of battle. As the troops approached' he pointed to the tree under which the

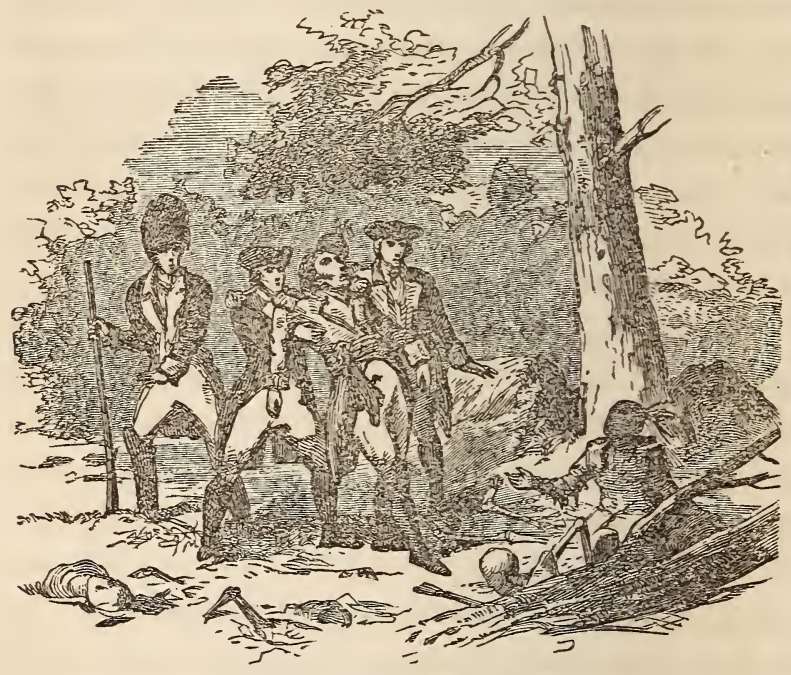

SEARCHING FOR THE DEAD.

officers had fallen. Captain West halted his men round the spot, and with Sir Peter Halket and the other officers, formed a circle, while the Indians removed the leaves which thickly covered the ground. The skeletons were found as the Indian expected, lying across each other. The officers having look- 
ed at them some time, the Major said that as his father had an artificial tooth, he thought he might be able to ascertain if they were indeed his bones and those of his brother. The. Indians were therefore ordered to remove the skeleton of the youth, and to bring to view that of the old officer. This was immediately done; and after a short examination Major Halket exclaimed, 'It is my father!' and fell back into the arms of his companions. The pioneers then dug a grave, and the bones being laid in it together, a Highland plaid was spread over them, and they were interred with the customary honors." The soldiers then returned.

After the reduction of Fort Duquesne, the English were resolved to follow up their advantages, and, if possible, to drive the French from all their strong posts at the north. A new expedition was fitted out against Ticonderoga and Crown Point. This was more successful than the former one. For when General Amherst approached Ticonderoga with an overwhelming force, the French abandoned the fort, and hastily retreated to Crown Point. Amherst repaired the place, left a garrison for its defense, and then followed the retreating soldiers to Crown Point. He approached this place with great, but, as the event proved, with unnecessary caution. For when he reached it, he found it, like Ticonderoga, abandoned. These various forts were of 
great importance, and their possession gave the English the command of the northern portion of New York, and greatly assisted them in extending their domains over the American continent.

General Prideaux was dispatched with an army of British regulars, provincials, and Indians, to take Fort Niagara, situated on Lake Ontario, at the mouth of the Niagara river. He engaged in this enterprise with commendable spirit, but was killed by the bursting of a cannon.

After this unfortunate event, the command devolved on Johnson. Knowing the great importance of conquering Fort Niagura, Johnson, with his accustomed skill and energy, made a judicious disposition of his troops, sending some into the trenches to prevent a sally from the fort, and arranging others at safe intervals along the road from the fort to Niagara Falls, to cut off whaterer reinforcements might be sent to the French. His Indian allies he disposed on the sides or flanks of the army, where he believed they would render the most essential service. On July $24 \mathrm{th}$, about the middle of the forenoon, the French reinforcements, which had been expected, arrived. As they approached, the Mohawks, who were on the side of the English, proposed to hold a parley with the Indians who were in alliance with the French. This friendly proposal was declined. Immediately the rocks and forests 
echoed and re-echoed with the horrid, unearthly yells of these savages, who by their war cries indicated their design of indulging in their farorite diversion of shedding blood and gathering the scalps of their enemies. The French rushed upon the English with great impetuosity, pouring upon them a shower of balls which did fatal execution. But they were receired with great steadiness by the little army of Johnson. The battle soon became general. The British regulars and provincials effectually held them in check in front, while on the flank they were severely scathed by the fire of the Indians. It was an exciting scene. The mighty thundering of Niagara's cataract, mingled with the roar of the artillery, the demoniac shrieks of the savages, and the groans of the dying. The grass and beautiful summer flowers were stained by the crimson blood of the slain. Huge rolumes of smoke rose from the scene of conflict, shutting out the light of the sun and concealing the combatants as with a clondy tabernacle. It was all, howerer, of short duration. For with such spirit and steadiness did the English continue the engagement, that in less than an hour, the French gave way, and commenced to retreat. They were followed so closely and rigoronsly by Johnson, that the retreat soon became a rout. They were pursued many miles like a drove of hunted deer. Their general and all 
his officers were taken prisoners, while uncounted numbers fell, to suffer uncared for, to die unknown, and to decay unburied amid the primeval forests of the New World. The next morning, Johnson sent: word to the commandant of Fort Niagara that all his expected roinforcements were cut off; and advised him to capitulate without any more shedding of blood. When the commandant was convinced that this intelligence was correct, he saw the uselessness of attempting to hold out against a victorious army with the limited means at his command. He therefore surrendered at once. The garrison, consisting of about seven hundred men, were allowed to march out with the honors of war, retaining their baggage, and to have a safe escort to protect them from the ferocity of the Indians. Although there were more than a thousand savages in Johnson's army, yet none of them were allowed to torture a prisoner; so that the dreadful massacres which occurred at Fort William Henry and Oswego, were not retaliated upon the French. The captive soldiers were taken prisoners of war to Albany; but the women and children were, at their own desire, sent to Montreal, while the sick and the wounded, . who could not be removed, were treated with considerate humanity. The capture of Fort Niagara effectually cut off the French communication between Canada and Louisiana, which the English so 
much feared. All that now remained was for the English to get possession of Quebec and Montreal, and the French power in the northern part of America would be completely annihilated. How this was attempted, and what was the result, will be related in the next chapter.

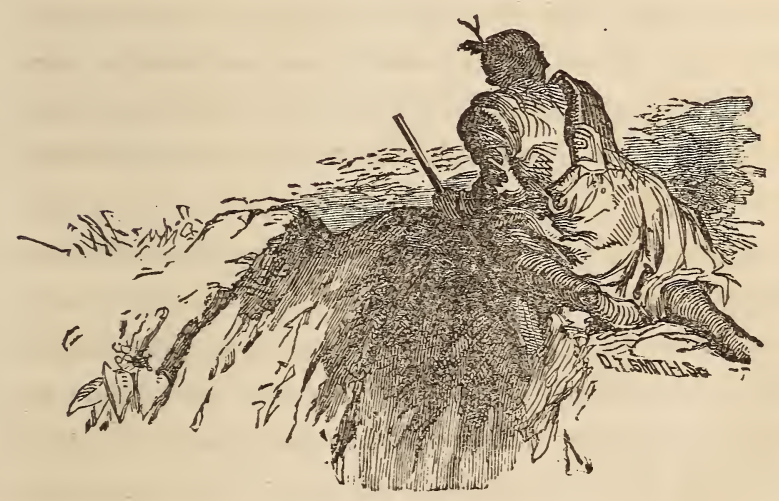

19 


\section{CHAPTER XIX.}

Situation of Quebec-Its strong Defenses-Montcalm's Army-His Military arrangements-A Fleet of Fire-ships-How they are disposed ofBatteries erected-Terrific Fire-stages-Battle of Montmorency-llljudged Assault-The English repulsed-The French fire upon the Wounded and the Dead-Their Apology for this Crueliy-General Wolfe sickA perilous Project-Wolfe approres it-Its great Difficulties-Courageous Midnight Adventure-Heights of Abraham gained-Preparations for Battle-Position of the two Armies-Battle on the Heights-Wolfe's Death in Victory-The Freuch Defeated-Death of Montcalm-Quebec taken by the Engiish.

Aroxg the most important operations of the English in their contest with France for the conquest of the New World, were their operations on the shores of the magnificent river St. Lawrence. Quebec was situated on the northern bank of this river, in a high precipitous location, the ascent to which, from the water, was exceedingly difficult. A few miles below it, that is, toward the east, the river Montmorency, a strong, rapid stream, emptied into and mingled its waters with those of the St. Lawrence, furnishing an important means of defense to the town; while still nearer, the St. Charles increased the difficulties of approach, not only by its channel, but also by immense marshes which were 
formed by the expansion of its waters over the low fiatlands at the eastern base of the town.

For the protection of the town, in addition to its strong natural defenses, General Montcalm had six battalions of soldiers and a number of Indian warriors, amounting in all to nine or ten thousand men. To orercome these difficulties, and to conquer this strongly intrenched army, General Wolfe had, in British regulars, Provincial soldiers and Indians, about eight thousand, who on the 26th of June, 1759 , arrived off the Isle of Orleans, on which they landed the next day. They here became acquainted with the numerous difficulties of their undertaking. All along below the town, down to the mouth of the Montmorency, and for nine miles above it, every point on the St. Lawrence, where it was probable the English would attempt to land, or from which it was possible to annoy them, there were forts, batteries, mortars, floating batteries, inflammable rafts and fire-boats, all ready for use the moment any occasion offered. On the night of the $28 \mathrm{th}$, about 12 o'clock, the English were startled by strange lights in the ricer above them; they grew brighter and brighter and approached nearer and nearer, until they illumined the whole river, and brought to view the various objects on both shores. They were a fleet of fire-ships, which the French had kindled and set adrift to be borne down by the combined 
force of the current and of a strong wind which was blowing at the time, in order to set the English fleet on fire. This fleet consisted of forty-four ships, frigates and other armed ressels, and if any important portion of them had been destroyed, it might have operated very unfavorably for the whole army. This, howerer, was prevented by the promptness, skill, and shrewdness of the British sailors; for so soon as they understood the nature and design of this fleet of flame, they manned their small boats, rowed toward the burning ressels, grappled them, and towed them ashore so that they did no injury whatever. The next night the English took possession of a point opposite Quebec, called Point Levi. They here erected batteries, and commenced throwing balls and shells into the town. These greatly alarmed the inhabitants, and set on fire a number of dwellings, but they produced no impression upon the fortifications. So high was the upper town abore the river, that no injury could be inflicted upon it by the ships. Engagements frequently took place between small parties of the French and English, but without any important results. A month rolled away. On the 29 th of July the enemy made another attempt to burn the British fleet. They constructed a raft of nearly a hundred fire-stages, and set it afloat upon the current of the river. It came down like a village in flames, but prored harmless. 
Wolfe now resolved to draw the enemy into action. Various projects were proposed. The most feasible. one was to attack a strong detachment of the French, who had taken their position upon the high bank of the Montmorency, near its mouth; if possible conquer them, and press on toward Quebec. This plan was adopted. In attempting to land the troops some of the boats got aground and furnished a mark for the enemy, who threw their balls and shells wherever they could produce execution. After considerable difficulty a landing was effected. A redoubt was taken. The foremost companies, under the excitement of the occasion, immediately rushed forward to drive the French from their intrenchments. This ill-judged morement proved disastrous ; for they were receired with unshrinking firmness by the French, who poured upon them such a welldirected fire as to throw them into disorder and oblige them to retreat. So great was the confusion produced by this repulse that it was impossible to form these men into line again, eren after other regiments had arrived, and had come to their relief. A thunder-storm now broke upon them, which greatily disheartened the English, but encouraged the enemy. The newly-arrived troops were brought into line with great promptness, and the officers displayed unusual courage, and many of them fell before the skillful fire of the French. Not satisfied 
with this, the enemy continued to fire upon those who had fallen, whether they were wounded or dead. TVhen afterward the French officers were remonstrated with for this unnecessary barbarity, their apology was, that this mal-treatment of the dying and the dead proceeded from the Canadians and the Indians, whom no discipline could control. This engag'ement was unfortunate for the English. General Wolfe, convinced that at the present time discretion was the better part of valor, ordered a retreat to the Isle of Orleans, but not till nearly five hundred men were slain. Wolfe was now taken down with disease, and his generals projected a plan of operations which they submitted for his consideration. It would require great caution, stillness, tact, self-possession, and courage, for its execution, still, under favorable circumstances it might prove successful. It was well adapted to the romantic and adventurous disposition of Wolfe, who was thirsting for some opportunity to pluck from the hand of fame a wreath of glory. The plan was to distract the attention of the enemy by various false movements up the river, far abore the town, and then, under the cover of darkness, to effect a landing near the torm, climb up the steep, precipitous bank, and gain the Heights of Abraham before the French should discover their object. Although Wolfe was unwell, yet his piercing glance had discovered a small core in the river, from which 
a narrow path, hardly wide enough for two to march abreast, led to the summit. This was selected as the place by which to gain the coreted eminence. It was an enterprise of extreme peril. The stream swept down past the core with a rapid current; the shore was shelving; the bank of the river lined with French sentinels; the landing-place so narrow as easily to be missed in the dark; and the cliff, which must be surmounted, so steep that it was difficult to ascend it even in open day and without opposition. Should the design be promulgated by a spy or deserter, or be suspected by the enemy; should the disembarkation be disordered through the darkness of the night, or the obstructions of the shore; the landing-place be mistaken, or one sentinel alarmed-the Heights of Abraham would instantly be covered with such numbers of troops as would render the attempt abortive, and defeat ineritable." All this Wolfe knew, and yet in view of it all he was undaunted. Believing the proverb that Fortune favors the brave, and saying to his men that "A victorious army knows no difficulties," he resolved to make the attempt. Accordingly the troops were taken on board the ressels, and then the fleet sailed sereral leagues up the St. Lawrence, as if with the intention of landing at that distance.

Montcalm dispatched Bougainrille with twelve or fifteen hundred men to observe their morements, 
and prevent them from reaching the shore. Several pretended attempts were made by the English to land. On the 12th of september, about an hour after midnight, Wolfe, and about half his army, embarked on board a large number of flat-boats and proceeded down the river. No sails nor oars were allowed to be used, lest they should lead to a discovery. Gradually and cautlously did they float down with the current, keeping near to the northern shore of the rirer, lest they should pass by the narrow core which had been selected as their landing-place. They came very near being discorered. Most of the sentinels on the shore did not observe them; but one or two did, and hailed them. This was a perilous moment. If it became known that these were boats loaded with English, the alarm would be given, and instantly the Heights of Abraham would be corered with the French, and all landing effectually prevented; the enterprise would prove a splendid failure, and result in the loss of many men. All this was escaped by the presence of mind of a shrewd Scotchman, who, when they were challenged by the sentinels, replied that they were a part of the troops of Bougainville, and were employed in examining the condition of the river and watching the movements of the English. This was satisfactory, and they were allowed to proceed. As they were slowly adrancing toward 
their object, Wolfe repeated, in a low tone of voice, ret sufficiently loud for his officers in the same boat to hear, the beantiful "Elegy of Gray in a Comtry Church-yard," which had been recently printed, and which he had receired by the last mail firom England.

Beneath him were the deep black waters of the St. Lawrence, flowing onward with sullen music toward the ocean; around him were scattered hundreds of boats, filled with thousands of brave hearts panting for the achievements of to-morrow ; along the shore could be heard the regular foot-falls of the pacing sentinel, while here and there were seen the glimmering light of the timid or vigilant settler, and over all was the dome of heaven, dotted with innumerable stars, twinkling in their remotest depths as if they were the eyes of legions of angels gazing with trembling interest upon the exciting scene. Under such circumstances the suppressed roice of Wolfe was heard repeating-

"The boast of heraldry, the pomp of power, And all that beauty, all that wealth ere gave, A wait alike the inexorable hour;-

The paths of glory lead but to the grave," etc.

Having finished the poem, he added, in low but emphatic tones, "Gentlemen, I would rather be the author of that poem than take Quebec to-morrow." 
Abont an hour before the dawn, the landing mas accomplished, Wolfe being among the first that leaped on shore. When he locked up and sam the sieep height to be ascended before success could crown their enterprise, he said to an officer, "I doubt if you will get up; but you must do what you can." The ships which had been left behind arrived soon after.

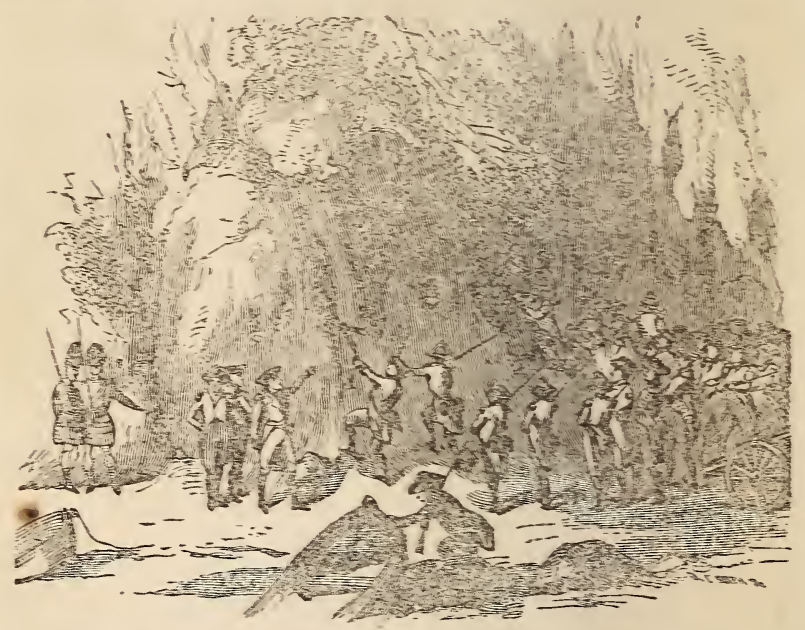

ASCENDING THE HEIGHTS OF ABR.AHAM,

Now commenced the perilous ascent. The Scotch Highlanders under Colonel Howe took the lead, and were followed by the others with as much caution and stillness as was possible. By clinging to the branches of trees, projecting rocks, 
and roots that protruded finm the bank, they managed to reach the top. Here a little firing seattered the sentinels, and when the sun rose abore the horizon, its rars were reflected from the wenpons of the whole English amy. The Heights of Abraham were successfully gained. Then the intelligence was conveyed to Montcalm, he could not believe it possible. "It can be," said he, "but a small party come to burn a few houses and then retire."

But when assured that the whole army of the British had gained the heights, he was startled. "Then they have finally reached the weak side of this miserable garrison," said he; but, nothing daunted, he immediately added, " We must give battle, and crush them before mid-day." Fully realizing the peril of his position, and the immense interests dependent upon his morements, he at once made arrangements for an engagement. Leaving his camp at Montmorency, he passed over the St. Charles, hastened onward to the Heights of Abraham, and disposed his forces in order of battle. Wolfe was soon prepared for his receptiou. The comparative strength of the two armies was about equal, each embracing about fire thousand men. The French had three small cannon, the Euglish only one or two. The two commanders, personally, took their positions directly opposite 
each other, Montcalm being on the left of the French army, and Wolfe on the right of the English; they thus confronted each other. The cannon of the two armies opened their fire and continued sending their balls with more or less effect for two hours. An attempt was made by a portion of the French,troops to attack the English upon the side of their line, and force them down the high bank into the St. Lawrence. This attempt was firustrated by Wolfe, who sent a detachment of his soldiers to the threatened position, where they were formed with a double front. Montcalm sent for fresh troops to come to his aid, but his ardent disposition could not wait for their arrival. He rushed forward with his soldiers, and attacked the English line with great bravery. They were received with firmness. When Wolfe saw them approaching, he ordered his men not to fire till the French were within forty yards of them. They then poured into them a rapid discharge of small arms, with fatal effect. The advance of the French was checked, and their ardor quenched, by the galling fire to which they were subjected. They soon began to waver. Wolfe, seizing an auspicious moment when the French companies were broken and irregular, ordered his soldiers to charge them with fixed bayoncts; they obeyed. They dashed upon them with great impetuosity, put the broken troops of 
Montcalm to flight at all points, and forced them to retreat in a disorderly manner.

In the early part of the action, Wolfe was wounded in the wrist. Wrapping his handkerchief around his arm, he continued to command and animate his troops till he received another wound in his groin. Still he would not retire from the field. Concealing his misfortune from his men, he led his grenadiers to the charge, when a ball struck him in the breast, and laid him prostrate upon the ground. He was immediately carried to the rear. While being supported by one of his lieutenants, he heard the cry, "They run, they run!" "Who run?" asked the dying Wolfe. "The French," replied the officer ; "they have given way at all points." "What," said the expiring general, "do they run already ?" After sending a few orders to his officers to make arrangements to head off the fugitives, so that they might not escape, he added, "Now, God be praised, I die happy;" and soon after expired upon the field of victory. Graham says of Wolfe : "He was intensely studious, and yet promptly and vigorously active; heroically brave and determined, adventurous and persevering; of a temper lively and even impetuous, yet never reproached as violent and irascible; generous, indulgent, courteous and humane, Wolfe was the pattern of his officers, and the idol of his soldiers. The force and compass 
of his genius enabled him practically to distinguish, what inferior minds never discovered at all, the diffurence between great difficulties and impossibilities; and being undiscouraged by what was merely, however, mightily difficult, he undertook and achieved what others would have accounted and found to be impossible."

It is a noteworthy coincidence that Montcalm found his death upon the same field, and in the same conflict. While animating his soldiers at the head of his battalion, he received a mortal wound. When informed by the surgeon that he could not recover, his reply was, "I am glad of it." He then asked, "How long shall I live?" "Ten or twelve hours ; perhaps less." "So much the better", said he, "I shall not live to witness the surrender of Quebec." When De Ramsay, the commander of the garrison of Quebec, consulted him respecting the practicability of defending the city, he replied, "To your keeping I commend the honor of France. As for me I shall pass the night with God, and prepare myself for death." About five o'clock the next morning he died. In a few days (September 17) the garrison of Quebec capitulated. The English immediately took possession of it, and found in it about ten thousand persons in addition to the troops.

By the terms of capitulation, the inhabitants were 
to be allowed the free exercise of their religion, during the continuance of the war, but their political disposition was left to be decided by the home governments at the close of hostilities. The day after the capitulation, a thousand prisoners were sent in transports to Europe. It was a fortunate thing for the English that Quebec surrendered so soon, as the defeated French forces had rallied, had received reinforcements, and were prepared to throw themselves into the city to assist the garrison on the very day it surrendered.

It was not long after the capitulation of Quebec before Montreal fell into the hands of the English. By this series of successful engagements, the gorernment of Great Britain obtained complete possession of Canada which she has retained ever since. 


\section{CHAPTER XX.}

Oprressive Acts of Parliament-Americar Opposition to them-Famous Stamp Act-Its Design-Its Effect in Naryland-The Maryland Gazetie-Treatment of Zechariah Hood-Stamped Paper not allowed to be landed-A ridiculous Ceremony-Hood burnt and whipped in Effigy -Popular Feeling more powerful than Government-The Times doleful and dollar-less-Stamp Act repealed.

Aster the subjugation of Canada, the Parliament of Great Britain adopted various injudicious and unpopular measures toward her American colonies. Without allowing them the right of sending a representative to Parliament, to give a proper statement of their condition, and to vote in their behalf, various oppressive acts were passed that only served to irritate the colonies and wean their affection from the mother country. Messages, remonstrances, protests, and appeals were published by the colonists. Numerous exciting meetings were called, at which their grievances were discussed, and measures of resistance proposed. During these

- painful collisions between England and her American dependencies, which prepared the way for the American Revolution, Maryland uniformily exhib- 
ited a bold front to her oppressors. She took an early and a decided stand against the unjust en. croachments of the home government. A memorable instance of this was exhibited in her opposition to the famous Stamp Act.

This was an act making it obligatory upon the colonists to use paper having the king's stamp upon it, in the ordinary transactions of business. If a receipt, or note, or any other important business document was written upon paper that was not stamped, it was not legal, and could not be prosecuted in a court of law. If this paper had been as cheap as any other kind, the law requiring its use would have been comparatively harmless. But it was not. The stamps were to be paid for. It was a measure that was designed to increase the income of the British treasury. This act consisted of fiftyfive specific duties, laid on as many different documents recorded on paper. Two pounds were imposed upon a college diploma; for a license to sell wine, twenty shillings; for a deed, one shilling and six pence; newspapers were taxed a penny ; pamphlets, a shilling per sheet; advertisements, two shillings, and almanacs, four pénce. This was in 1765 . When intelligence of the passage of this act reached America, it excited deep animosity. Maryland was not behind the other colonies in giving expression to the most decided opposition. The Maryland $20 *$ 
Gazette was converted into a channel throngh which the burning indignation of the people found vent. The pungent articles which there appeared served to increase and give permanency to the detestation of the community against this tyrannical measure. But the writing of newspaper articles was not the only way in which the displeasure of the public was developed.

On the 27th of August, 1765, a meeting was held at Annapolis, to show the abhorrence of the people against the Stamp Act, and the measures which had been adopted to circulate the stamped paper among the community. A Mr. Zechariah Hood, a native of the province of Maryland, who had been to England and purchased a cargo of goods, had been appointed to deliver the stamped paper in the province. When this fact was known, and also that he had brought with him a quantity of the obnoxious paper for distribution, the people were determined that he should not execute his mission, and that the stamped paper should not be landed. When the vessel arrived in the harbor of Annapolis, they rushed to the dock in crowds to prevent Hood from disembarking. So great avas the excitement that a fight ensued, and one of the crowd, Thomas McNier, had his thigh broken. Although this was the seat of government, so little influence had the officers of the crown, that they could not prevent the excited 
populace from the accomplishment of their purpose. Hood was obliged to diaw off, and effect a landing secretly. At the public meeting, which was called "to show their detestation of, and abhorrence to, some late tremendous attacks on liberty and their dislike to a certain late arrived officer, a native of

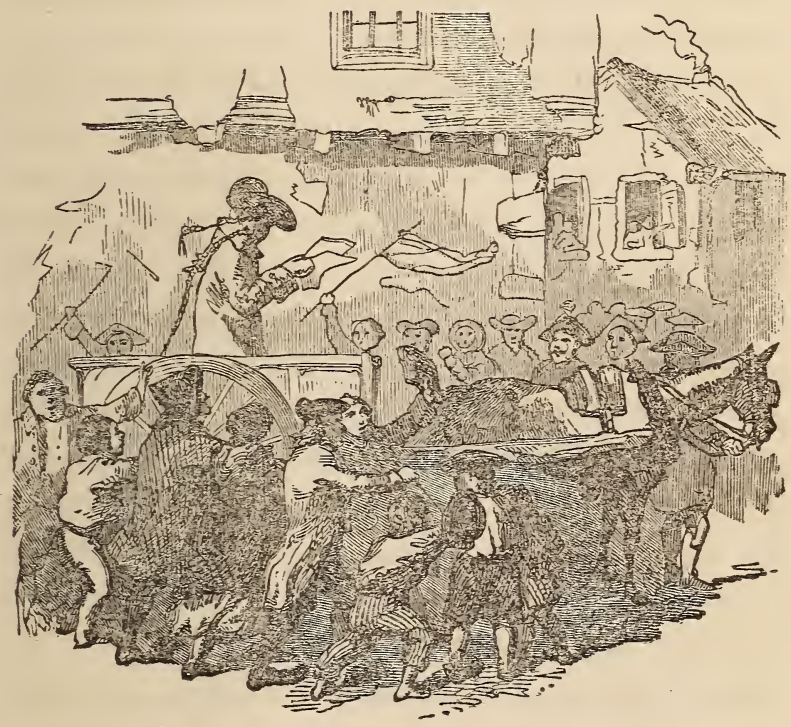

HOOD RIDING IN EFFIGY.

this province! they curiously dressed up the figure of a man, which they placed in a one-horse cart, malefactor like, with some sheets of paper in his hands before his face. In that manner they paraded 
through the streets of the town, till noon, the bell at the same time tolling a solemn knell, when they proceeded to the hill, and after giving it forty lashes save one, which they called giving it the Mosaic law, at the whipping-post, placed it in the pillory, from whence they took it and hung it on a gibbet, there erected for that purpose, and set fire to a tarbarrel underneath, and burned it till it fell into the barrel. By the many significant nods of the head, while in the cart, it may be said to have gone off very penitently." Hood, who was in this indignant manner whipped, pilloried, hung and burned in effigy, found that Annapolis was a poor market for his cargo of merchandise. The people would not trade with him. He was compelled therefore to go elsewhere, which he did just before he was executed in effigy. In his haste to flee he left behind a quantity of tar and feathers with which his fellow-citizens intended to cover him, as an appropriate reward for the zeal he had displayed in the execution of the Stamp Act.

So violent was the indignation of the people against this measure of Parliament, that the colonial officers in the correspondence with their home government expressed their inability to see it executed. As a specimen of the nature of this correspondence, the following extract of a letter is inserted. It is from Governor Sharpe to the Earl of Halifax, and dated 
Annapolis, 5th September, 1765. After giving an account of the treatment of Mr. Hoor, he says, "To what length people, who have made such a beginning, may go to render the act of Parliament ineffectual, I can not tell, but am very apprehensive that if the stamped paper was to arrive here and be landed at this time, it would not be in my power to preserve it from being burned, as there is no place of security here wherein it might be lodged; and the militia is composed of.such as are by no means proper to be appointed a guard over it; if therefore a vessel should soon arrive here with the stamped paper, I shall caution the master against landing it, and shall advise him either to lie off at a distance from the shore, or return to the men-of-war stationed in Virginia until the people show a better disposition, or I have the satisfaction to receive from your Lordship some instructions about it." This acknowledgment of weakness on the part of the civil authorities is additional evidence of the deepseated opposition of the people and of the danger which attended the enforcement of this oppressive law.

The acts of Governor Sharpe were in harmony with the above letter. For in the following December another ressel arrived at Annapolis, having on board a quantity of the stamped paper for the province of Maryland. But as no person who was 
authorized to receive and distribute it was there to take charge of it, and as the Lower House of the provincial Legislature were opjosed to its reception, it was never landed. Three boxes of this obnoxions paper were sent back to England by Governor Sharpe in a merchant ship the same month.

It is the proud boast of Maryland that her soil was never polluted with any of this odious papernone was ever landed there.

Among other modes of expressing the extreme regret of the people at the unpopular measure, a supplement of the Maryland Gazette was issued in deep mourning. Rather than submit to the "intolerable and burdensome terms," which were imposed on all newspapers, the editor determined to discontinue printing the Gazette, stating in a quaint alliteration that

\section{The times are \\ Dreadful, \\ Dismal, \\ Doleful, \\ Doiorous, \\ Dollarless.}

As in the course of a few weeks it became apparent that the Americans would not submit to this unjust measure of Parliament, the editor issued what was termed "an apparition of the late Maryland Gazette," and resolved to republish his paper, under 
the firm conviction that the government woud be utterly unable to carry into effect the odious Stamp Act. Opposition similar to that of Maryland was exlibited in various colonies. As it was utterly impossible for the officers of the king to carry the stamp act into execution, it was soon repealed by Parliament. This gave great joy to the colonies. The repeal was every where celebrated with the firing of cannon, bonfires, illuminations, and various other demonstrations of gladness.

Still the British government continued to adopt oppressive measures against America, until finally the colonies determined to separate themselves from the mother country. A congress of all the States was held, which published to the world the famous "Declaration of Independence." Then follower the long and bloody war of the Revolution, which resulted in pliwing the United States among the free and iudependent nations on the earth. 
$\downarrow$ 


